DOE/EIA-0603(98)

\title{
Renewable Energy Annual 1998 With Data For 1997
}

\author{
December 1998
}

\author{
Energy Information Administration
}

Office of Coal, Nuclear, Electric and Alternate Fuels

U.S. Department of Energy

Washington, DC 20585

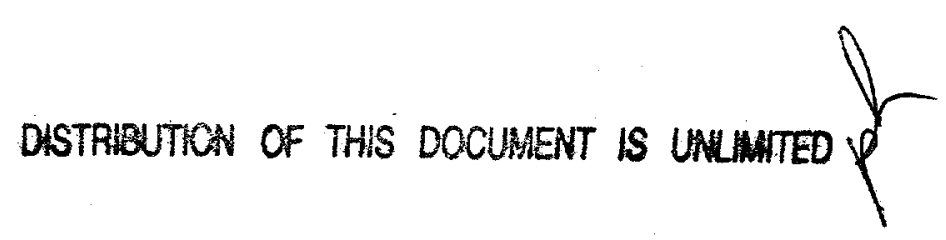

MASTER

This report was prepared by the Energy Information Administration, the independent statistical and analytical agency within the U.S. Department of Energy. The information contained herein should be attributed to the Energy Information Administration and should not be construed as advocating or reflecting any policy of the Department of Energy or any other organization. 


\section{Contacts}

This report was prepared by the staff of the Renewable Information Team, Coal, Nuclear, and Alternate Fuels Division, Office of Coal, Nuclear, Electric and Alternate Fuels. General information regarding this publication may be obtained from Fred Mayes, Team Leader
(202/426-1166, e-mail fred.mayes@eia.doe. gov). Questions about the preparation and content of the report should be directed to Louise Guey-Lee, project coordinator (202/426-1143, e-mail louise.gueylee@eia.doe. gov).

Questions regarding specific information in the report should be directed as follows:

1. Renewable Data Overview

Fred Mayes Louise Guey-Lee

2. Biomass Energy Robert Lowe

3. Municipal Solid Waste ........... John Carlin

4. Geothermal Energy ............... Fred Mayes

5. Geothermal Heat Pumps ............ Peter Holihan

6. Wind Energy ................ Louise Guey-Lee

7. Solar Thermal and Photovoltaic ....... Peter Holihan

8. Technology ................. Lawrence Prete

9. References ................. Mark Gielecki
202/426-1166

$202 / 426-1143$

202/426-1171

202/426-1146

202/426-1166

202/426-1147

202/426-1143

202/426-1147

$202 / 426-1161$

$202 / 426-1141$ fred.mayes@eia.doe.gov louise.guey-lee@eia.doe.gov robert.lowe@eia.doe.gov john.carlin@eia.doe.gov fred.mayes@eia.doe.gov james.holihan@eia.doe.gov louise.guey-lee@eia.doe.gov james.holihan@eia.doe.gov lawrence.prete@eia.doe.gov mark.gieleck@eia.doe.gov 


\section{DISCLAIMER}

This report was prepared as an account of work sponsored by an agency of the United States Goverament Neither the United States Governmeat aor any ageacy thereof, nor any of their employees, makes any warnaty, express or implied, or sesumes any legal liability or responsibility for the accuracy, completeness, or usefulness of any information, apparatus, product, or process disclosed. or represents that its use would not infringe privately owned rights. Refereace berein to any speciric commercial product, process, or service by trade name, tradernart, manufacturer, or otherwise does not necessarily constitute or imply its endorsement, recommendation, or favoring by the United States Government or any agency thereof. The views and opinions of authors expressed herein do not necessarily state or refleet those of the. United States Government or any agency thereof. 


\section{DISCLAIMER}

Portions of this document may be illegible in electronic image products. Images are produced from the best available original document. 


\section{Preface}

This is the fourth annual report published by the Energy Information Administration (EIA) which presents information on renewable energy consumption, capacity, and electricity generation data; U.S. solar thermal and photovoltaic collector manufacturing activities; and U.S. geothermal heat pump manufacturing activities. It updates and provides more detail on renewable energy information than what's published in the Energy Information Administration's (EIA) Annual Energy Review 1997.

The renewable energy resources included in the report are: biomass (wood, wood waste, municipal solid waste, ethanol, and biodiesel); geothermal; wind; solar (solar thermal and photovoltaic); and hydropower. However, hydropower is also regarded as a "conventional" energy source because it has furnished a significant amount of electricity for more than a century. Therefore, the contribution of hydropower to total renewable energy consumption is discussed, although hydropower as an individual energy source is not addressed. Since EIA collects data only on terrestrial (land-based) systems, satellite and military applications are not included in this report.

The first chapter provides an overview of renewable energy use and capability from 1993 through 1997. It discusses renewable energy consumption, and electric capacity and generation data. Chapter 2 presents current (through 1997) information on the United States solar energy industry. EIA collected this information on the Form EIA-63 A, "Annual Survey of Solar Collector Manufacturers," and the Form EIA-63 B, "Annual Survey of Photovoltaic Module/Cell Manufacturers," covering the 1997 calendar year. Chapter 3 presents, for the first time, information on the United States geothermal heat pump industry. This information was collected on the Form EIA-902, "Annual Geothermal Heat Pump Manufacturers Survey," and covers the calendar years, 1994-1997.

Appendix A describes EIA surveys that include information on renewable energy sources. Appendix $B$ discusses renewable energy data and its limitations. Appendix $C$ presents documentation for the geothermal heat pump manufacturers survey. Appendix D provides a list of Internet addresses for web sites that include renewable energy information. Appendix $E$ lists State agencies that provide energy information, including information on renewable energy. A glossary of renewable energy terms is also included.

The Energy Information Administration was established formally by the Department of Energy Organization Act of 1977 (Public Law 95-91). The legislation requires EIA to carry out a comprehensive, timely, and accurate program of energy data collection and analysis. It also vests EIA with considerable independence in fulfilling its mission. 


\section{Contents}

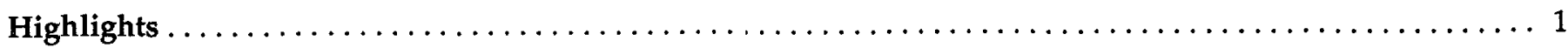

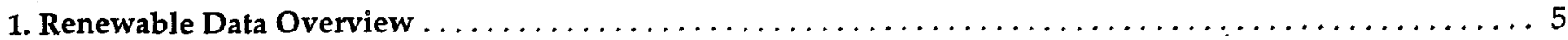

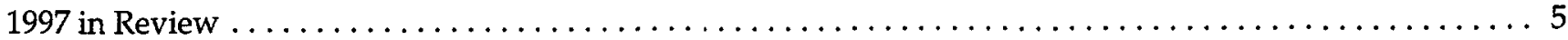

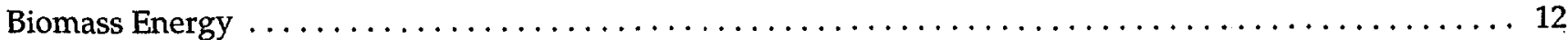

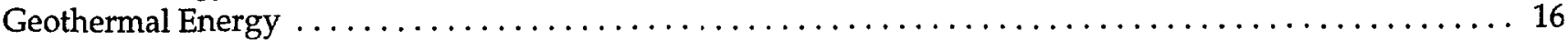

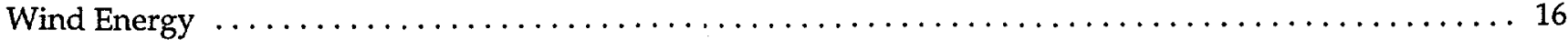

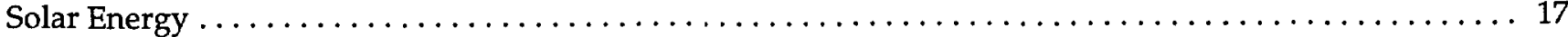

2. Solar Thermal and Photovoltaic Collector Manufacturing Activities $\ldots \ldots \ldots \ldots \ldots \ldots \ldots \ldots \ldots \ldots \ldots$

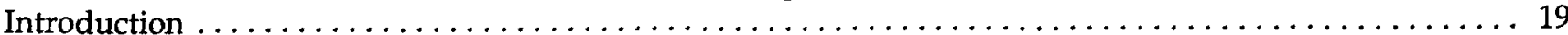

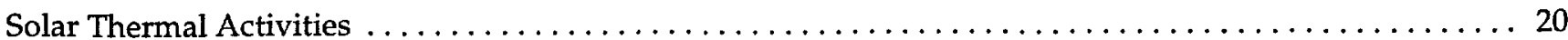

Photovoltaic Module and Cell Manufacturing Activities $\ldots \ldots \ldots \ldots \ldots \ldots \ldots \ldots \ldots \ldots \ldots \ldots$

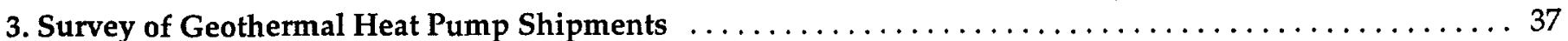

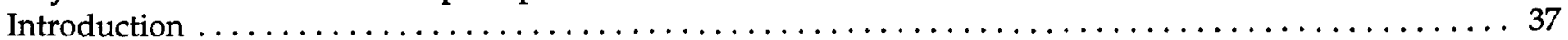

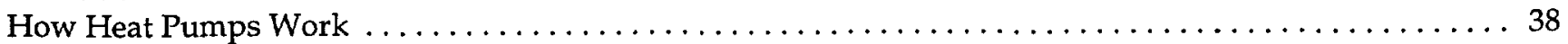

Appendices

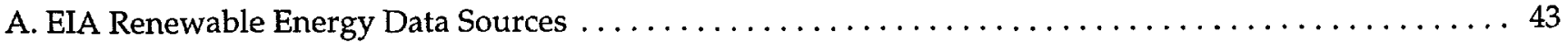

B. Renewable Data Limitations $\ldots \ldots \ldots \ldots \ldots \ldots \ldots \ldots \ldots \ldots \ldots \ldots \ldots \ldots \ldots \ldots \ldots \ldots \ldots$

C. Geothermal Heat Pump Survey Methodology ............................. 51

D. Selected List of Internet Addresses: Renewable Energy Information by Resource $\ldots \ldots \ldots \ldots \ldots \ldots 63$

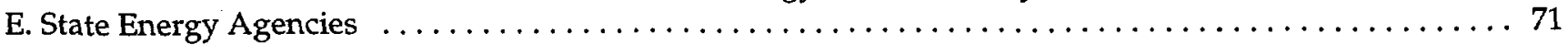

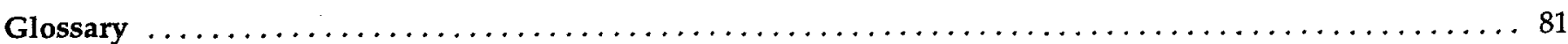


H1. U.S. Renewable Energy Consumption by Energy Source, $1993-1997 \ldots \ldots \ldots \ldots \ldots \ldots \ldots \ldots \ldots \ldots$. . . . 2

1. U.S. Energy Consumption by Energy Source, $1993-1997 \ldots \ldots \ldots \ldots \ldots \ldots \ldots \ldots \ldots \ldots \ldots \ldots \ldots \ldots . \ldots$

2. Renewable Energy Consumption by Sector and Energy Source, $1993-1997 \ldots \ldots \ldots \ldots \ldots \ldots \ldots \ldots \ldots$

3. Renewable Energy Consumption for Electricity Generation by Energy Source, 1993-1997 . . . . . . . . . 8

4. Electricity Generation From Renewable Energy by Energy Source, $1993-1997 \ldots \ldots \ldots \ldots \ldots \ldots \ldots$. . . . 9

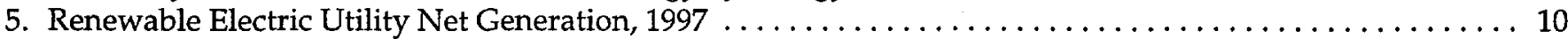

6. Nonutility Gross Generation From Renewables, $1997 \ldots \ldots \ldots \ldots \ldots \ldots \ldots \ldots \ldots \ldots \ldots \ldots \ldots \ldots$

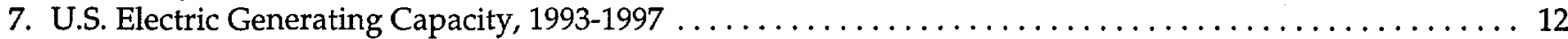

8. Biomass Energy Consumption by Sector and Census Region, $1993-1997 \ldots \ldots \ldots \ldots \ldots \ldots \ldots \ldots \ldots$

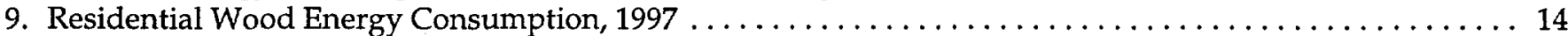

10. U.S. Utility Net Electric Generation from Solar Energy, $1997 \ldots \ldots \ldots \ldots \ldots \ldots \ldots \ldots \ldots \ldots \ldots \ldots \ldots$

11. Annual Photovoltaic and Solar Thermal Shipments, $1978-1997 \ldots \ldots \ldots \ldots \ldots \ldots \ldots \ldots \ldots \ldots \ldots$

12. Annual Shipments of Solar Thermal Collectors, $1987-1997 \ldots \ldots \ldots \ldots \ldots \ldots \ldots \ldots \ldots \ldots \ldots \ldots \ldots 20$

13. Annual Shipments of Solar Thermal Collectors by Type, $1987-1997 \ldots \ldots \ldots \ldots \ldots \ldots \ldots \ldots \ldots \ldots 21$

14. Shipments of Solar Collectors Ranked by Top Five Origins and Destinations, 1996 and $1997 \ldots \ldots \ldots .21$

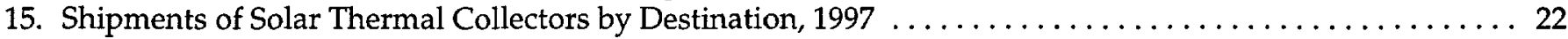

16. Distribution of U.S. Solar Thermal Collector Exports by Country, $1997 \ldots \ldots \ldots \ldots \ldots \ldots \ldots \ldots \ldots 23$

17. Distribution of Solar Thermal Collector Shipments, 1996 and $1997 \ldots \ldots \ldots \ldots \ldots \ldots \ldots \ldots \ldots \ldots . \ldots \ldots$

18. Solar Thermal Collector Shipments by Type, Quantity, Value, and Average Price, 1996 and 1997 . . . .. 25

19. Shipments of Solar Collectors by Market Sector, End Use, and Type, 1996 and $1997 \ldots \ldots \ldots \ldots \ldots 26$

20. Shipments of Complete Solar Thermal Collector Systems, 1996 and $1997 \ldots \ldots \ldots \ldots \ldots \ldots \ldots \ldots$

21. Number of Companies Expecting To Introduce New Solar Thermal Collector Products in $1998 \ldots \ldots \ldots 27$

22. Percent of Solar Collector Shipments by the 10 Largest Companies, $1987-1997 \ldots \ldots \ldots \ldots \ldots \ldots \ldots 27$

23. Companies Involved in Solar Thermal Activities by Type, 1996 and $1997 \ldots \ldots \ldots \ldots \ldots \ldots \ldots \ldots 28$

24. Solar-Related Sales as a Percentage of Total Sales, 1996 and $1997 \ldots \ldots \ldots \ldots \ldots \ldots \ldots \ldots \ldots \ldots \ldots$

25. Annual Shipments of Photovoltaic Cells and Modules, $1995-1997 \ldots \ldots \ldots \ldots \ldots \ldots \ldots \ldots \ldots \ldots \ldots . \ldots 28$

26. Annual Shipments of Photovoltaic Cells and Modules, $1986-1997 \ldots \ldots \ldots \ldots \ldots \ldots \ldots \ldots \ldots \ldots \ldots$

27. Distribution of Photovoltaic Cells and Modules, $1995-1997 \ldots \ldots \ldots \ldots \ldots \ldots \ldots \ldots \ldots \ldots \ldots \ldots \ldots$

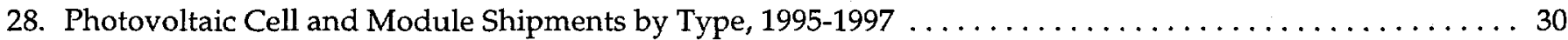

29. Photovoltaic Cell and Module Shipment Values by Type, 1996 and $1997 \ldots \ldots \ldots \ldots \ldots \ldots \ldots \ldots . \ldots . \ldots$

30. Shipments of Photovoltaic Cells and Modules by Market Sector, End Use, and Type, 1996 and 1997 . . . . 32

31. Export Shipments of Photovoltaic Cells and Modules by Type, 1996 and 1997 . . . . . . . . . . . . 33

32. Destination of U.S. Photovoltaic Cell and Module Export Shipments by Country, $1997 \ldots \ldots \ldots \ldots$. . . . 34

33. Shipments of Complete Photovoltaic Module Systems, $1995-1997 \ldots \ldots \ldots \ldots \ldots \ldots \ldots \ldots \ldots \ldots \ldots$

34. Employment in the Photovoltaic Manufacturing Industry, $1991-1997 \ldots \ldots \ldots \ldots \ldots \ldots \ldots \ldots \ldots \ldots$

35. Companies Expecting to Introduce New Photovoltaic Products in $1998 \ldots \ldots \ldots \ldots \ldots \ldots \ldots \ldots \ldots . \ldots \ldots$

36. Number of Companies Involved in Photovoltaic-Related Activities, 1996 and 1997 . . . . . . . . . . 35

37. Geothermal Heat Pump Shipments by Model Type, $1994-1997 \ldots \ldots \ldots \ldots \ldots \ldots \ldots \ldots \ldots \ldots \ldots . \ldots \ldots$

38. Capacity of Geothermal Heat Pump Shipments by Model Type, $1994-1997 \ldots \ldots \ldots \ldots \ldots \ldots \ldots \ldots . .37$

39. Geothermal Heat Pump Shipments by Exports, Census Region, and Model Type, 1996 and 1997 . . . . . 39

40. Geothermal Heat Pump Shipments by Customer Type and Model Type, 1996 and 1997 . . . . . . . . . 40

B1. Evaluation of EIA's Undercoverage of Nonutility Electricity Data $\ldots \ldots \ldots \ldots \ldots \ldots \ldots \ldots \ldots \ldots . \ldots \ldots$

B2. Preliminary and Final Nonutility Renewable Generation Data Comparison $\ldots \ldots \ldots \ldots \ldots \ldots \ldots \ldots 48$

B3. Geothermal Direct Use of Energy and Heat Pumps $\ldots \ldots \ldots \ldots \ldots \ldots \ldots \ldots \ldots \ldots \ldots \ldots \ldots$ 


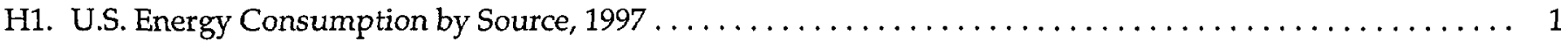

1. Renewable Energy Consumption by Source, $1993-1997 \ldots \ldots \ldots \ldots \ldots \ldots \ldots \ldots \ldots \ldots \ldots \ldots$

2. U.S. Biomass Energy Consumption by Major Sectors, $1993-1997 \ldots \ldots \ldots \ldots \ldots \ldots \ldots \ldots \ldots \ldots \ldots \ldots 14$

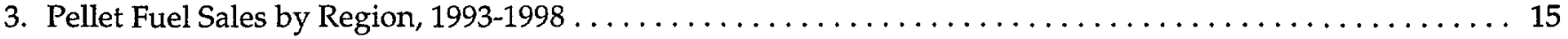

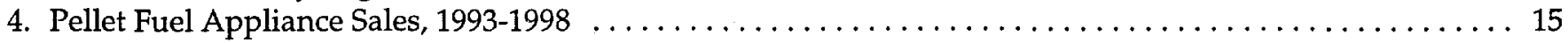

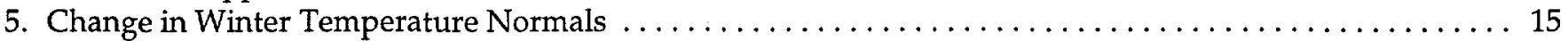

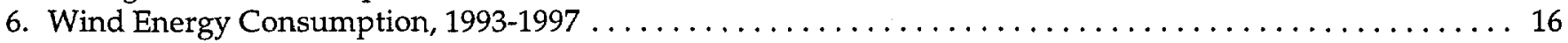

7. Import and Export Shipments of Solar Thermal Collectors, $1987-1997 \ldots \ldots \ldots \ldots \ldots \ldots \ldots \ldots \ldots \ldots$

8. Solar Thermal Collector Shipments by Collector Type, $1986-1997 \ldots \ldots \ldots \ldots \ldots \ldots \ldots \ldots \ldots \ldots \ldots 24$

9. Average Price of Solar Thermal Collector Shipments by Collector Type, 1995, 1996, and 1997 . . . . . . 25

10. Import and Export Shipments of Photovoltaic Cells and Modules, $1988-1997 \ldots \ldots \ldots \ldots \ldots \ldots \ldots$

11. Photovoltaic Cell and Module Shipments by Type, $1994-1997 \ldots \ldots \ldots \ldots \ldots \ldots \ldots \ldots \ldots \ldots \ldots \ldots \ldots$

12. Ground Coupled Heat Pumps-Loop Configurations $\ldots \ldots \ldots \ldots \ldots \ldots \ldots \ldots \ldots \ldots \ldots \ldots \ldots \ldots .40$ 


\section{Highlights}

\section{Renewable Energy Consumption}

Renewable energy consumption declined 3 percent between 1996 and 1997 to 7.1 quadrillion Btu, accounting for 8 percent of total U.S. energy consumption (Figure $\mathrm{H} 1$ and Table $\mathrm{H} 1$ ). Hydropower and biomass continued to dominate the renewable energy market, with 55 percent and 38 percent shares, respectively. With hydropower consumption flat between 1996 and 1997, most of the year-to-year drop was due to a decrease in biomass energy consumption due to a warmer than expected heating season. In addition, geothermal energy consumption declined 9 percent. Wind and solar energy together contributed a small but steady 0.1 quadrillion Btu.

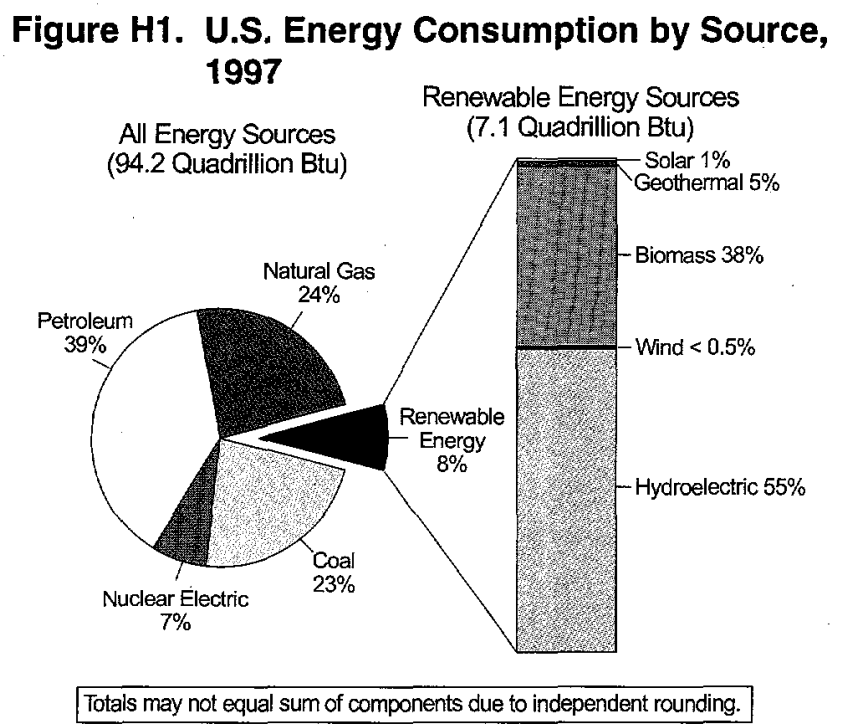

Sources: Energy Information Administration (EIA), Annual Energy Review 1997, DOE/EIA-0384(97) (Washington, DC, July 1998), Table 1.3. 1997 Renewable Energy: Consumption values based on the sum of electricity consumption from EIA, Electric Power Annual 1997, Volume II, DOE/EIA-0348(97)/2 (Washington, DC, October 1998), and non-electricity consumption based on analysis by the Office of Coal, Nuclear, Electric and Alternate Fuels.

Renewable energy consumption in the transportation sector (ethanol in motor gasoline) experienced an increase of 23 trillion Btu, or 31 percent. Renewable energy consumption decreased in all other sectors, particularly residential and industrial. Total renewable energy consumption (including net imports) for electricity generation declined 1 percent overall, despite a 4percent rise to 95 gigawatts in renewable electric generating capacity. Most of the capacity gain was accounted for by a 3,358-megawatt increase in conventional hydroelectric generating capacity. Biomass generating capacity rose 171 megawatts, while wind capacity declined 57 megawatts, as retirements exceeded additions.

\section{Solar Manufacturing Activities}

\section{Shipments}

Shipments of photovoltaic (PV) cells and modules continued their record growth in 1997, increasing 31 percent. Correspondingly, the value of these shipments increased 34 percent. The growth in shipments is due largely to a strong export market, which represented 73 percent of shipments in 1997, compared with 63 percent in 1996.

Photovoltaic cells and modules shipments totaled 46 peak megawatts in 1997, compared with 35 peak megawatts in 1996. This marks the twelfth consecutive annual increase in shipments. The value of shipments grew to \$175 million in 1997 from \$131 million in 1996. The average annual rate of increase in shipments over the past 12 years has been 21 percent. Overall unit peak watt price showed a 2-percent increase from 1996 to 1997.

Shipments of solar thermal collectors increased 7 percent in 1997 to 8.1 million square feet from 7.6 million square feet in 1996. The average price of solar thermal collectors decreased by 9 percent, resulting in a decrease in the value of shipments to $\$ 29$ million in 1997 from $\$ 29.8$ million in 1996.

Other major findings about the photovoltaic and solar thermal collector manufacturing activities include:

- Single crystal silicon PVs led the way in growth from 22 peak megawatts in 1996 to 30 peak megawatts in 1997, while cast and ribbon 
Table H1. U.S. Renewable Energy Consumption by Energy Source, 1993-1997

(Quadrillion Btu)

\begin{tabular}{|c|c|c|c|c|c|}
\hline Energy Source & 1993 & 1994 & 1995 & 1996 & 1997 \\
\hline Conventional Hydroelectric Power ${ }^{a}$ & $\mathrm{R} 3.147$ & R2.969 & R3.472 & R3.914 & 3.932 \\
\hline Geothermal Energy ${ }^{b} \ldots \ldots \ldots$ & Ro.393 & R0.395 & Ro.339 & Ro.352 & 0.322 \\
\hline Biomass $^{c} \ldots . . .$. & 2.784 & 2.838 & 2.846 & R2.938 & 2.723 \\
\hline Solar Energy ${ }^{\mathrm{d}}$ & 0.071 & 0.072 & 0.073 & 0.075 & 0.074 \\
\hline Wind Energy $\ldots \ldots \ldots \ldots \ldots \ldots \ldots \ldots$ & 0.031 & 0.036 & 0.033 & R0.035 & 0.035 \\
\hline Total Renewable Energy $\ldots \ldots \ldots \ldots \ldots \ldots$ & R6.426 & R6.309 & R6.763 & $\mathbf{R 7 . 3 1 5}$ & 7.086 \\
\hline
\end{tabular}

${ }^{a}$ Hydroelectricity generated by pumped storage is not included in renewable energy.

bincludes grid-connected electricity, geothermal heat pump and direct use energy.

Includes wood, wood waste, peat, wood sludge, municipal solid waste, agricultural waste, straw, tires, landfill gases, fish oils, and/or other waste.

Includes solar thermal and photovoltaic.

$R=$ Revised data.

Notes: See Appendix B, "Renewable Data Limitations," for a detailed explanation of data issues. Totals may not equal sum of components due to independent rounding.

Sources: 1993-1995: Energy Information Administration (E:IA), Annual Energy Review 1997, DOE/EIA-0384(97) (Washington, DC, July 1998), Table 1.3. 1996 and 1997: Consumption values based on the sum of electricity consumption from ElA, Electric Power Annual 1997, Volume II, DOE/EIA-0348(97)/2 (Washington, DC, October 1998), and non-electricity consumption based on analysis by the Office of Coal, Nuclear, Electric and Alternate Fuels.

crystalline silicon PVs increased from 12 peak megawatts in 1996 to 14 peak megawatts in 1997. Overall, crystalline silicon PVs accounted for 96 percent of shipments in 1997.

- PV shipments to the commercial sector experienced the greatest rate of growth from 1996 to 1997, rising 57 percent. The industrial and residential sectors showed growth rates of 42 percent and 30 percent respectively. Utility sector shipments grew 19 percent.

- The use of PVs in grid-interactive electricity gene:ation increased over 70 percent, while sales for remote electricity applications decreased 21 percent. Shipments to Original Equipment Manufacturers (OEMs) increased 118 percent. OEMs integrate PVs into devices that are used in the areas of telemetry, instrument controls and monitoring, remote quality testing, and measurement of flows and pressures. PVs represent a value added electricity source for remote usage of diverse manufactured goods.

- Ninety-three percent of shipments of solar thermal collectors were low temperature types in 1997 as compared to 90 percent in 1996. Ninety-one percent were used in the residential sector in 199'7, and 93 percent were installed as pool heaters.

\section{Industry Developments}

The Department of Energy launched the Million Solar Roofs Program in mid-1997. The initiative contains four core components that use existing funding and legislative authorities. These components include: "aggressive" federal procurement in cost-effective applications; enhancement of access to and blending of several existing federal loan programs with long-term amortization; use of five existing technology grant programs for "buy down"; and the establishment of an interagency team to ensure results and coordinate maximum efficiency. By 2010 , these systems are expected to be self- sustaining.

Siemens Solar Industries announced delivery of a record-efficient, 1-kilowatt (peak) thin-film photovoltaic array to the National Renewable Energy Laboratory (NREL). The 28-module array has an average module power of 39 watts peak (Wp) and an efficiency of 9 percent. The modules incorporate Siemens' newest improvement in copper-indium-diselenide-based thinfilm technology, which was developed with support from NREL's Thin -Film PV Partnership Program. The best module of the array produced $40.6 \mathrm{Wp}$ for a record efficiency of 11.1 percent.

The Sacramento Municipal Utility District's (SMUD) board of directors approved a 10-megawatt (peak) photovoltaic program for $1998-2002$. The $\$ 22$ million in 
contracts approved were expected to create major PV module and inverter factories in 1998. Projects included building-integrated PVs in Grass Valley, a $\$ 19.3-$ million supply contract with Energy Photovoltaics, and the purchase of $8 \mathrm{MWe}$ of power inverters from Trace Engineering.

AstroPower Inc. announced it bested its previous sunlight-to-electricity conversion efficiency record and fabricated a 16.6 percent efficient thin-film silicon solar cell under a collaboration with the NREL. The record was set on a laboratory-scale device measuring 1 square centimeter as part of the Department of Energy's Photovoltaic Manufacturing Technology Initiative. The prior record, set a few years ago, was 14.6 percent.

The Department of Defense stated that it offers the potential of nearly 20,000 photovoltaic applications in 33 categories, according to an analysis prepared by the
Photovoltaic Review Committee. Applications include a building guard station, remote building operations, cathodic protection, communications equipment, lights, meteorologicalstations, navigational assistance, housing, instrumentation, observation tower, radar equipment, security, transportable power and water pumping.

\section{Geothermal Heat Pump Manufacturing Activities}

For the first time in this report the Energy Information Administration (EIA) is presenting the results of its "Annual Geothermal Heat Pump Manufacturers Survey." This survey was completed by approximately 18 known manufacturers of geothermal heat pumps. Results indicated that for 1994 through 1997, a cumulative total of 209,000 units were shipped. 



\section{Renewable Data Overview}

\section{In Review ${ }^{1}$}

\section{Total Consumption}

Renewable energy consumption declined 3 percent to 7.086 quadrillion British Thermal Units (Btu) between 1996 and 1997, as hydropower imports decreased and exports increased from 1996 (Table 1). Excluding net imports, renewable energy consumption declined about 1.5 percent. Hydropower contributed 55 percent of renewable energy consumption in 1997 (Figure 1). ${ }^{2}$ Since 1993, renewable energy consumption has grown at a 2.5percent annualized rate, compared with 1.9 percent for total U.S. energy consumption.

Table 1. U.S. Energy Consumption by Energy Source, 1993-1997

(Quadrillion Btu)

\begin{tabular}{|c|c|c|c|c|c|}
\hline Energy Source & 1993 & 1994 & 1995 & 1996 & 1997 \\
\hline \multicolumn{6}{|l|}{ Fossil Fuels } \\
\hline Coal...... & R19.837 & R20.027 & R20.090 & R21.011 & 21.439 \\
\hline Coking Coal (Net Imports) ... & 0.017 & 0.024 & 0.026 & * & 0.018 \\
\hline Natural Gas ${ }^{a} \ldots \ldots \ldots$ & 20.827 & 21.288 & 22.163 & R22.560 & 22.588 \\
\hline Petroleum ${ }^{b}$. & 33.841 & 34.735 & 34.663 & R35.864 & 36.314 \\
\hline Total Fossil Fuels . . . . . . . . & R74.522 & R76.073 & R76.943 & R79.434 & 80.360 \\
\hline Nuclear Electric Power $\ldots \ldots \ldots \ldots \ldots \ldots \ldots$ & 6.519 & 6.837 & 7.177 & R7.168 & 6.686 \\
\hline Hydroelectric Pumped Storage ${ }^{c} \ldots \ldots \ldots \ldots$ & R-0.042 & -0.035 & -0.028 & R-0.032 & -0.042 \\
\hline \multicolumn{6}{|l|}{ Renewable Energy } \\
\hline Conventional Hydroelectric Power ${ }^{d}$ & R3.147 & R2.969 & R3.472 & R3.914 & 3.932 \\
\hline Geothermal Energy ${ }^{e} \ldots \ldots \ldots \ldots$ & Ro.393 & R0.395 & Ro.339 & Ro.352 & 0.322 \\
\hline Biomass $^{f} \ldots \ldots \ldots$. . & 2.784 & 2.838 & 2.846 & R2.938 & 2.723 \\
\hline Solar Energy & 0.071 & 0.072 & 0.073 & 0.075 & 0.074 \\
\hline Wind Energy $\ldots \ldots \ldots \ldots$ & 0.031 & 0.036 & 0.033 & Ro.035 & 0.035 \\
\hline Total Renewable Energy...$\ldots \ldots \ldots \ldots$ & R6.426 & R6.309 & R6.763 & $\mathbf{R 7 . 3 1 5}$ & 7.086 \\
\hline Total Energy Consumption $\ldots \ldots \ldots \ldots \ldots \ldots$ & R87.368 & R89.250 & R90.864 & R93.871 & 94.151 \\
\hline
\end{tabular}

${ }^{\text {a }}$ Includes supplemental gaseous fuels.

${ }^{b}$ Petroleum products supplied, including natural gas plant liquids and crude oil burned as fuel.

${ }^{\mathrm{C}}$ Represents total pumped-storage facility production minus energy used for pumping.

${ }^{d}$ Hydroelectricity generated by pumped storage is not included in renewable energy.

Includes grid-connected electricity, geothermal heat pump and direct use energy.

Includes wood, wood waste, peat, wood sludge, municipal solid waste, agricultural waste, straw, tires, landfill gases, fish oils, and/or other waste.

Includes solar thermal and photovoltaic.

$\mathrm{R}=$ Revised data.

* = value less than 0.0005 quadrillion Btu.

Notes: See Appendix B, "Renewable Data Limitations," for a detailed explanation. Totals may not equal sum of components due to independent rounding.

Sources: 1993-1997: Energy Information Administration (EIA), Annual Energy Review 1997, DOE/EIA-0384(97) (Washington, DC, July 1998), Table 1.3. 1996 and 1997 Renewable Energy: Consumption values based on the sum of electricity consumption from EIA, Electric Power Annual 1997, Volume II, DOE/EIA-0348(97)/2 (Washington, DC, October 1998), and non-electricity consumption based on analysis by the Office of Coal, Nuclear, Electric and Alternate Fuels.

1 Calculated statistics in this chapter are based on unrounded data. In contrast, data presented in tables may be rounded.

2 All renewable consumption and production information shown in this chapter was derived from the Integrated Renewable Energy Database System (IREDS). The data values in IREDS are more precise than those shown in the tables of this report. 
Figure 1. Renewable Energy Consumption by Source, 1993-1997

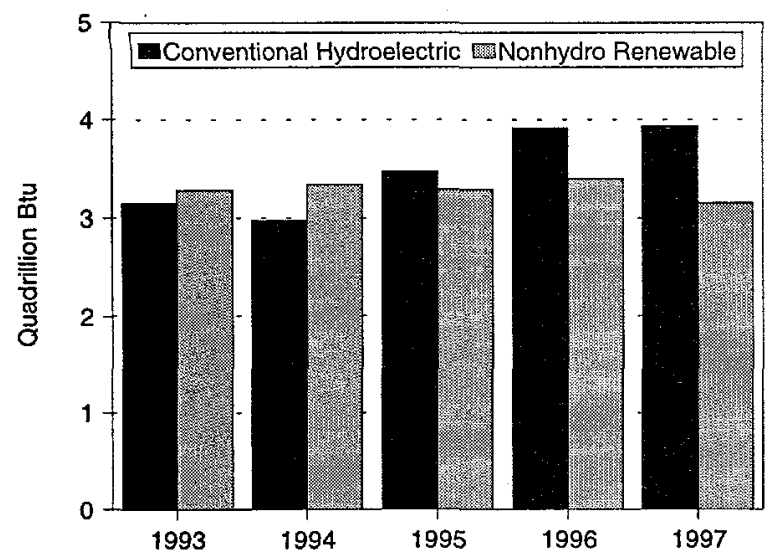

Sources: 1993-1995: Energy Information Administration (EIA), Annual Energy Review 1997, DOE/EIA-0384(97) (Washington, DC, July 1998), Table 1.3. 1996 and 1997: Consumption values based on the sum of electricity consumption from EIA, Electric Power Annual 1997, Volume II, DOE/EIA-00348(97)/2 (Washington, DC, October 1998), and non-electricity consumption based on analysis by the Office of Coal, Nuclear, Electric and Alternate Fuels.

Biomass energy consumption, which accounted for 38 percent of total renewable energy consumption, declined 7 percent from 1996. Geothermal, solar, and wind energy, which combined provided 6 percent of total renewable energy in 1997, declined 7 percent.

The renewable share of total energy consumption declined slightly from 7.8 percent in 1996 to 7.5 percent in 1997. Regarding total energy consumption, about one-half of the increase in fossil fuel energy consumption was offset by a decline in nuclear electricity generation.

\section{Sectoral Consumption}

Renewable energy consumption increased only in the transportation sector between 1996 and 1997, rising from 0.074 quadrillion Btu to 0.097 quadrillion Btu (Table 2). The energy represented here is ethanol blended into gasoline as an oxygenate in low percentage blends (under 10 percent).

Residential sector consumption declined nearly 25 percent. This was largely due to a drop in biomass energy consumption, attributed to higher-than-expected winter temperatures lowering heating demand. Residential energy consumption now includes energy consumption from geothermal (ground water) heat pumps, which amounted to 0.0075 quadrillion Btu in 1997.

Industrial sector renewable energy consumption declined 3 percent in 1997 to 2.555 quadrillion Btu. Most of the decrease was in industrial biomass consumption, which decreased nearly .070 quadrillion Btu. Also, an 11-percent decline in industrial geothermal consumption more than offset an increase in consumption for conventional hydropower.

Electric utility sector renewable energy consumption remained virtually unchanged in 1997 at 3.881 quadrillion Btu. This sector consumed 55 percent of renewable energy consumption in 1997 and includes net renewable imports.

Of the 2.207 quadrillion Btu of renewable energy not used to generate electricity, 70 percent was in the industrial sector, where considerable biomass-based process heat is used in areas such as the forest products industry (especially for paper and pulp operations). Industrial biomass process heat applications alone consumed 1.554 quadrillion Btu, 70 percent of total nonelectric renewable energy consumption. Another 25 percent is consumed in the residential sector for heating and cooling.

\section{Electricity Generation}

Energy used to generate 457 billion kilowatthours (kWh) of renewable-based, domestically-consumed electricity amounted to 4.879 quadrillion Btu (Tables 3 and 4). Domestically consumed and produced renewable generation $^{3}$ in 1997 was nearly 2 percent above 1996 levels.

Total hydropower generation rose 11.6 billion $\mathrm{kWh}$ in 1997, due principally to a 10.3-billion $\mathrm{kWh}$ increase in utility generation. On a percentage basis, nonutility (industrial ${ }^{4}$ ) hydropower rose a substantial 8 percent. These gains were due principally to greater water availability in the Northwest.

3 "Domestic generation" equals total renewable electricity generation less net electricity imports.

4 Although the category "industrial " is used, there are actually two subcategories, not easily distinguishable. A pure industrial facility may loosely be described as one designed principally to provide energy for a manufacturing or other product-making use, while a nonutility is a special category of facility which is usually designed to generate electric power and connect to the grid. Nonutilities are often those designated by the Federal Energy Regulatory Commissicn as "qualifying facilities," so-called because they meet certain criteria set forth by PURPA. However, a "pure industrial" facility may sell power to the grid, and a nonutility can generate energy for the entity's own use. 
Table 2. Renewable Energy Consumption by Sector and Energy Source, 1993-1997 (Quadrillion Btu)

\begin{tabular}{|c|c|c|c|c|c|}
\hline Sector and Source & 1993 & 1994 & 1995 & 1996 & 1997 \\
\hline \multicolumn{6}{|l|}{ Residential/Commercial } \\
\hline Biomass $\ldots . . . \ldots \ldots$ & 0.592 & 0.582 & 0.641 & Ro.644 & 0.475 \\
\hline Solar ...... & 0.062 & 0.064 & 0.065 & R0.066 & 0.065 \\
\hline Geothermal $^{\mathrm{a}}$ & 0.010 & 0.010 & 0.011 & $\mathrm{R} 0.012$ & 0.013 \\
\hline 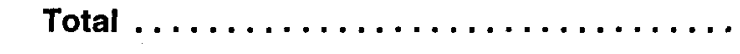 & R0.664 & R0.656 & Ro.717 & R0.722 & 0.553 \\
\hline \multicolumn{6}{|l|}{ Industrial $^{\mathbf{b}}$} \\
\hline Biomass .. & 2.084 & 2.138 & R2.084 & R2.200 & 2.132 \\
\hline Geothermal $^{\mathrm{a}} \ldots \ldots \ldots \ldots$ & R0.206 & Ro.214 & Ro.210 & R0.217 & 0.194 \\
\hline Conventional Hydroelectric ${ }^{c}$ & Ro.119 & 0.136 & 0.152 & Ro.171 & 0.185 \\
\hline Solar $\ldots \ldots \ldots \ldots \ldots$ & 0.009 & 0.008 & 0.008 & Ro.009 & 0.009 \\
\hline Wind & 0.031 & 0.036 & 0.033 & Ro.035 & 0.035 \\
\hline Total $\ldots \ldots \ldots \ldots \ldots \ldots \ldots \ldots \ldots \ldots$ & R2.449 & R2.533 & R2.487 & R2.633 & 2.555 \\
\hline \multicolumn{6}{|l|}{ Transportation } \\
\hline Biomass $^{d} \ldots$ & 0.088 & 0.097 & 0.104 & Ro.074 & 0.097 \\
\hline \multicolumn{6}{|l|}{ Electric Utility } \\
\hline Biomass ... & 0.020 & 0.020 & 0.017 & Ro.020 & 0.019 \\
\hline Geothermal $^{\mathrm{a}} \ldots \ldots \ldots \ldots$ & 0.158 & 0.145 & 0.099 & Ro.110 & 0.115 \\
\hline Conventional Hydroelectric $^{c}$ & R2.774 & $\mathrm{R} 2.547$ & R3.054 & R3.422 & 3.528 \\
\hline Solar and Wind $\ldots \ldots \ldots \ldots$ & * & * & $\cdot$ & • & * \\
\hline Net Renewable Energy Imports ${ }^{e}$ & Ro.272 & Ro.310 & 0.284 & R0.334 & 0.219 \\
\hline Total $\ldots \ldots \ldots \ldots \ldots \ldots \ldots \ldots \ldots \ldots$ & R3.225 & R3.023 & R3.454 & R3.886 & 3.881 \\
\hline Total Renewable Energy Consumption $\ldots \ldots \ldots$ & R6.426 & R6.309 & R6.763 & R7.315 & 7.086 \\
\hline
\end{tabular}

ancludes geothermal heat pump and direct use energy. The Industrial and Electric Utility sectors also include grid connected electricity.

Includes generation of electricity by cogenerators, independent power producers, and small power producers.

${ }^{c}$ Hydroelectricity generated by pumped storage is not included in renewable energy.

dEthanol blended into gasoline.

Includes only net imports of electricity known to be from renewable resources (geothermal and hydroelectric).

$R=$ Revised data.

*Less than 0.0005 quadrillion Btu.

Note: Totals may not equal sum of components due to independent rounding.

Sources: 1993-1995: Energy Information Administration (EIA), Annual Energy Review 1997, DOE/EIA-0384(97) (Washington, DC, July 1998), Table 10.2. 1996 and 1997: Electricity Consumption-EIA, Electric Power Annual 1997, Volume //, DOE/EIA0348(97)/2 (Washington, DC, October 1998). Non-electricity Consumption (except imports)-Based on analysis by the Office of Coal, Nuclear, Electric and Alternate Fuels. Net Renewable Energy Imports, 1993-1997: Based on analysis by the Office of Coal, Nuclear, Electric and Alternate Fuels.

Electricity generation from all other renewable sources fell; after rising in 1996, total geothermal generation dropped to 14.6 billion in 1997, a decline of 6 percent. Nonutility geothermal generation decreased 10 percent, while utility generation ${ }^{5}$ managed a small gain. Generation from biomass declined to 58 billion $\mathrm{kWh}$, largely due to a 4-percent drop in nonutility generation. Solar generation declined about 1 percent in 1997, despite the fact that utility solar generation increased 9.8 percent.
Wind-based electricity showed virtually no change. Nonutilities produce virtually all of the solar and wind electricity. (See Appendix B, "Data Description and Limitations," for an explanation of potential estimation errors in nonutility data.) Because information which EIA collects from non-utilities on the Form EIA-867, "Annual Nonutility Power Producer Report," is confidential, it is not possible to make any statements about individual plant operations.

5 Utility geothermal generation is principally from a single geothermal field in California known as "The Geysers." 
Table 3. Renewable Energy Consumption for Electricity Generation by Energy Source, 1993-1997 (Quadrillion Btu)

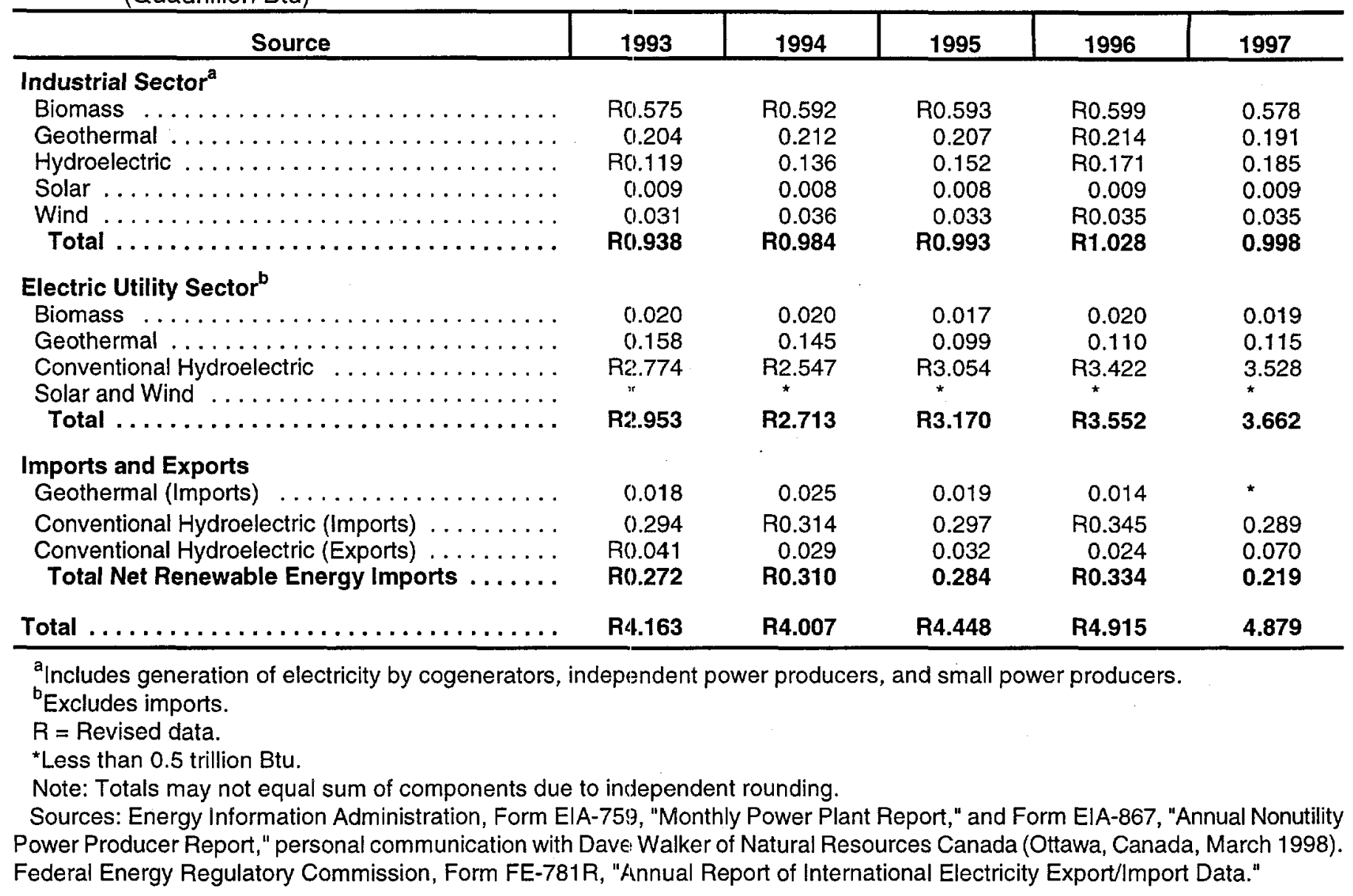

Electricity imports decreased 16 percent to 28 billion $\mathrm{kWh}$ in 1997 . With U.S. electricity exports nearly tripling to 6.8 billion $\mathrm{kWh}$, net electricity imports dropped by one-third to 21 billion $\mathrm{kWh}$ in 1997. This was the principal reason that total renewable electricity generation dropped 0.4 percent, compared with the 2percent gain in electricity generated and consumed domestically. Total renewable energy consumption in 1997 for electricity generation (including net imports) was 4.879 quadrillion Btu. The 436 billion kWh of renewable electricity generation domestically produced and consumed was about 12 percent of the U.S. total. ${ }^{5}$

In the utility sector, there are 6 or fewer plants in each of the categories. In the case of wind, the Solano plant operated by Sacramento Municipal Utility District (SMUD) generates about 99 percent of total utility wirid generation. For solar, there were 4 plants that generated electricity in 1997. One plant, Solar 2, operated by
Sacramento Municipal Utility District (SMUD), increased output by two-thirds in 1997, providing about 56 percent of utility solar generation. As a result, utility sector solar generation rose, despite the fact that output from two of the three other solar/PV generating plants decreased.

Resource accessibility largely determines where renewable electricity is generated. Access to water power makes Washington the leading producer of renewable energy, accounting for 24 percent of total renewable electricity produced in 1997 (Tables 5 and 6).

A second major factor influencing the use of renewables is State policies promoting renewable energy. The combined effect of resource availability and energy policy makes California the second-largest producer of renewable electricity generation. In 1997, 13 percent of utility renewable generation nationwide occurred in California.

6 EIA estimates total electricity generation in 1997 to be 3,494 billion kilowatthours. See Energy Information Administration, Electric Power Annual 1997, Volume II, DOE/EIA-0348(97)/2 (Washington, DC, October 1998). 
Table 4. Electricity Generation From Renewable Energy by Energy Source, 1993-1997 (Thousand Kilowatthours)

\begin{tabular}{|c|c|c|c|c|c|}
\hline $\begin{array}{c}\text { Source } \\
\end{array}$ & 1993 & 1994 & 1995 & 1996 & 1997 \\
\hline \multicolumn{6}{|l|}{ Industrial Sector (Gross Generation) ${ }^{2}$} \\
\hline Biomass $\ldots \ldots \ldots \ldots \ldots \ldots$ & $\mathrm{R} 55,745,781$ & $57,391,594$ & $R 57,513,666$ & $R 57,937,058$ & $55,886,586$ \\
\hline Geothermal & $9,748,634$ & $10,122,228$ & $9,911,659$ & $\mathrm{R} 10,197,514$ & $9,110,297$ \\
\hline Hydroelectric & $11,510,786$ & $13,226,934$ & $14,773,801$ & $R 16,555,389$ & $17,904,653$ \\
\hline Solar. & 896,796 & 823,973 & 824,193 & $\mathrm{R} 902,830$ & 892,892 \\
\hline Wind & $3,052,416$ & $3,481,616$ & $3,185,006$ & $\mathrm{R} 3,399,642$ & $3,384,576$ \\
\hline $\begin{array}{l}\text { Total } \ldots \ldots \ldots \ldots \ldots \ldots \ldots \ldots \ldots \ldots \\
\text { Electric Utility Sector (Net Generation) }\end{array}$ & $\mathbf{R} 80,954,413$ & $85,046,345$ & R86,208,325 & $\mathrm{R} 88,992,433$ & $87,179,004$ \\
\hline Biomass $\ldots \ldots \ldots \ldots \ldots \ldots \ldots$ & $\mathrm{R} 1,986,535$ & $R 1,985,463$ & $\mathrm{R} 1,647,247$ & $\mathrm{R} 1,912,472$ & $1,861,532$ \\
\hline Geoth & $7,570,999$ & $6,940,637$ & $4,744,804$ & $5,233,927$ & $5,469,110$ \\
\hline Conventional Hydroelectric & $269,098,329$ & $247,070,938$ & $296,377,840$ & $R 331,058,055$ & $341,273,443$ \\
\hline Solar. & 3,802 & 3,472 & 3,909 & 3,169 & 3,481 \\
\hline Wind. & 243 & 309 & 11,097 & 10,123 & 5,977 \\
\hline $\begin{array}{l}\text { Total } \ldots \ldots \ldots \ldots \ldots \ldots \ldots \ldots \ldots \\
\text { Imports and Exports }\end{array}$ & $\mathrm{R} 278,659,908$ & $\mathbf{R} 256,000,819$ & $R 302,784,897$ & $\mathrm{R} 338,217,746$ & $348,613,543$ \\
\hline Geothermal (Imports) $\ldots \ldots \ldots \ldots$ & 877,058 & $1,172,117$ & 884,950 & 649,514 & 10,313 \\
\hline Conventional Hydroelectric (ll & 28,55 & 30,4 & 28,823 & 33,35 & $27,990,905$ \\
\hline ectric (Exports) .... & $3,938,973$ & $2,806,712$ & 3,059 & 340 & $6,790,778$ \\
\hline Total Net Imports . . . . . . . . . . . . & $25,496,219$ & $28,844,268$ & $26,648,933$ & $31,673,157$ & $21,210,440$ \\
\hline Total Renewable Electricity Generation .. & R385,110,540 & R369,891,432 & R415,642,155 & R458,883,336 & $457,002,987$ \\
\hline \multicolumn{6}{|c|}{ 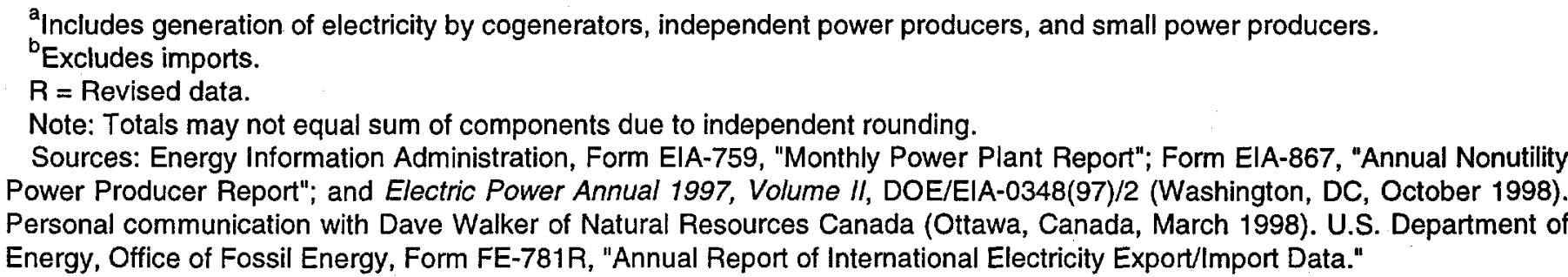 } \\
\hline
\end{tabular}

California's share of nonutility renewable electricity was even larger at 22 percent (Table 6). California promoted renewable energy strongly in the 1980's with renewable tax credits and other measures. In addition, California has the vast majority of the Nation's developed geothermal energy resources, as well as significant wind, solar, biomass (wood and waste), and hydroelectric resources.

Utilities in Oregon, which has sizable water power resources, produced the third-largest amount of electricity from renewables. New York contributed 8 percent, virtually all from water power. No other State contributed more than about 4 percent of total U.S. utility renewable generation.

Nonutility renewable generation outside California is more evenly spread. One reason is that nonutility plants are usually smaller than utility plants, having been built in many instances to service a single facility (e.g., pulp and paper manufacturing plant). Thus, many more resource locations are available, particularly for biomass and hydropower. After California, the States with the most nonutility electricity generation in 1997 were Florida, Maine, Louisiana, New York, Alabama, and North Carolina. The nonutility sector produces virtually all of the biomass-, wind-, and solar-powered electricity generation. Florida leads the Nation in nonutility biomass-generated power.

\section{Renewable Generating Capacity}

By the end of 1997, renewable generating capacity increased 3.7 percent to 95.3 gigawatts (Table 7). Hydroelectric capacity had the largest increase (3.4 gigawatts) between 1996 and 1997. Renewable capacity at the end of 1997 was nearly 3 percent greater than it was at the end of 1993, when it stood at 92.6 gigawatts. 
Table 5. Renewable Electric Utility Net Generation, 1997 (Thousand Kilowatthours)

\begin{tabular}{|c|c|c|c|c|c|c|c|c|c|}
\hline & $\begin{array}{l}\text { Hydro- } \\
\text { electric }\end{array}$ & Geothermal & $\begin{array}{c}\text { Solar/ } \\
\text { PV }\end{array}$ & Wind & $\begin{array}{c}\text { MSW } \\
\text { Landfill Gas }\end{array}$ & $\begin{array}{c}\text { Wood and } \\
\text { Wood } \\
\text { Waste }\end{array}$ & $\begin{array}{l}\text { Other } \\
\text { Waste }^{a}\end{array}$ & Total & Percent \\
\hline Alabama ..... . & $11,520,637$ & - & -- & -- & - & -- & - & $11,520,637$ & 3.3 \\
\hline Alaska ........ & $1,098,953$ & -- & -. & -- &.- & -- & - & $1,098,953$ & 0.3 \\
\hline Arizona $\ldots . .$. & $12,049,393$ & - & - & -. & -. & - & -- & $12,049,393$ & 3.5 \\
\hline Arkansas ..... & $3,511,260$ & -- & - & -. & -. & -- & -- & $3,511,260$ & 1.0 \\
\hline California ..... & $38,783,138$ & $5,300,592$ & 3,269 & 5,859 & -- & -- & -- & $44,092,858$ & 12.6 \\
\hline Colorado . . . . . . & $1,897,813$ & -- & -- & -- & -- & -- & -- & $1,897,813$ & 0.5 \\
\hline Connecticut .... & 374,110 & -- & -- & -- & 450,749 & -- & - & 824,859 & 0.2 \\
\hline Delaware ...... & -- & -- & -- & -- & -- & $\cdots$ & -- & -- & - \\
\hline Dist. of Col. . . . . . & -- & - & -- & -- & -- & - & -- & -- & - \\
\hline Florida . . . . . . . . & 241,280 & -- & - & -- & -- & -- & -- & 241,280 & 0.1 \\
\hline Georgia . . . . . . . . & $4,228,269$ & - & -. & -- & -- & -- & -- & $4,228,269$ & 1.2 \\
\hline Hawaii . . . . . . . & $\quad 18,791$ & -- & -- & -- & -- & -- & -- & 18,791 & -- \\
\hline Idaho.......... & $13,511,728$ & -- & -- & -- & -- & $\cdots$ & -- & $13,511,728$ & 3.9 \\
\hline Illinois . . . . . . & 16,773 & -- & -- & $\cdots$ & -- & -- & 23,595 & 40,368 &.- \\
\hline Indiana ....... & 561,593 & - & - & $m$ & -- & -- & - & 561,593 & 0.2 \\
\hline lowa ........ & 794,739 & -- & -- & 118 & 22,360 & $\cdots$ & -- & 817,217 & 0.2 \\
\hline Kansas . . . . . . . & -. & -- & -. & -. & -- & -- & -- & -- & -- \\
\hline Kentucky ..... & $3,380,233$ & -- & -- & -- & -- & -- & - & 3,$380 ; 233$ & 1.0 \\
\hline Louisiana . . . . . & $=$ & -- & -- & -- & -- & -- & -- & -- & - \\
\hline Maine ........ & $1,779,887$ & - & -- & - & -- & -- & -- & $1,779,887$ & 0.5 \\
\hline Maryland . . . . . . & $1,588,375$ & -- & -- & -- & -- & -- & - & $1,588,375$ & 0.5 \\
\hline Massachusetts . . & 788,540 & -- & -- & -- & -- & - & -- & 788,540 & 0.2 \\
\hline Michigan . . . . . . & $1,592,707$ & -- & -- & -- & $\cdots$ & -- & -- & $1,592,707$ & 0.5 \\
\hline Minnesota . . . . . . & 697,224 & - & -- & -- & 425,416 & 3,917 & + & $1,126,557$ & 0.3 \\
\hline Mississippi $\ldots \ldots$ & -. & -- & -- & -- & -- & -- & -- & -- & -- \\
\hline Missouri ...... & $1,593,309$ & -- & - & $\cdots$ & 41,704 & -- & - & $1,635,013$ & 0.5 \\
\hline Montana . . . . . . & $13,348,499$ & - & - & -- & - & - & -- & $13,348,499$ & 3.8 \\
\hline Nebraska ...... & $1,672,419$ & $\cdots$ & $\cdots$ & $\cdots$ & -- & -- & 624 & $1,673,043$ & 0.5 \\
\hline Nevada ........ & $2,567,451$ & -- & -- & -- & -- & -- & -. & $2,567,451$ & 0.7 \\
\hline New Hampshire . & $1,165,007$ & -- & -- & -- & -- & -- & -- & $1,165,007$ & 0.3 \\
\hline New Jersey . . . . & $\cdots$ & -- & - & - & - & -- & - & $\cdots$ & $\cdots$ \\
\hline New Mexico .... & 258,810 & -- & -- & -- & -- & -- & -- & 258,810 & 0.1 \\
\hline New York . . . . . . & $29,004,673$ & -- & - & -- & -- & 17,793 & -- & $29,022,466$ & 8.3 \\
\hline North Carolina .. & $3,894,248$ & -- & -- & -. & -- & -. & - & $3,894,248$ & 1.1 \\
\hline North Dakota ... & $3,319,577$ & $-\cdot$ & -- & - & -- & -- & -- & $3,319,577$ & 1.0 \\
\hline Ohio ........ & 507,368 & -- & -- & -- & -- & -- & -- & 507,368 & 0.1 \\
\hline Oklahoma ...... & $2,921,206$ & -- & -- & -- & -- & -- & $\rightarrow$ & $2,921,206$ & 0.8 \\
\hline Oregon ........ & $46,283,275$ & -- & -- & - & -- & -- & -- & $46,283,275$ & 13.3 \\
\hline Pennsylvania ... & $1,778,998$ & -- & -- & -- & -- & -- & -- & $1,778,998$ & 0.5 \\
\hline Rhode Island ... & -- & -- & -- & -- & -- & -- & - & - & - \\
\hline South Carolina .. & $2,901,794$ & $\cdots$ & - & - & -- & -- & -- & $2,901,794$ & 0.8 \\
\hline South Dakota ... & $9,012,260$ & -- & -- & -- & -- & -- & $\cdots$ & $9,012,260$ & 2.6 \\
\hline Tennessee .... & $10,073,313$ & -- & -- & - & -- & -- & -- & $10,073,313$ & 2.9 \\
\hline Texas ........ & $1,784,629$ & -- & 212 & - & -- & -- & -- & $1,784,841$ & 0.5 \\
\hline Utah $\ldots \ldots \ldots$ & $1,330,578$ & 168,518 & -- & -- & -- & -- & -- & $1,499,096$ & 0.4 \\
\hline Vermont ...... & 896,312 & -- & -- & -- & -- & 150,345 & -- & $1,046,657$ & 0.3 \\
\hline Virginia ....... & 939,569 & -- & $\cdots$ & -. & - & - & . - - & 939,569 & 0.3 \\
\hline Washington ... & $103,644,592$ & -- & -- & - & - & 353,256 & -- & $103,997,848$ & 29.8 \\
\hline West Virginia ... & 377,192 & -- & -- & -- & - & - & - & 377,192 & 0.1 \\
\hline Wisconsin . . . . . & $2,182,208$ & -- & -- & -- & 12,085 & 213,980 & 145,708 & $2,553,981$ & 0.7 \\
\hline Wyoming $\ldots \ldots$ & $1,380,713$ & -- & -- & -- & - & - & -- & $1,380,713$ & 0.4 \\
\hline Total ....... & $341,273,443$ & $5,469,110$ & 3,481 & 5,977 & 952,314 & 739,291 & 169,927 & $348,613,543$ & \\
\hline
\end{tabular}

${ }^{a}$ Agricultural waste, straw, tires, fish oils, paper pellets, tall oil, sludge waste, and waste alcohol. --=Not applicable.

Note: Totals may not equal sum of components due to independerit rounding.

Sources: Energy Information Administration, Form EIA-759, "Monthly Power Plant Report," and Form EIA-860, "Annual Electric Generator Report." 
Table 6. Nonutility Gross Generation From Renewables, 1997 (Thousand Kilowatthours)

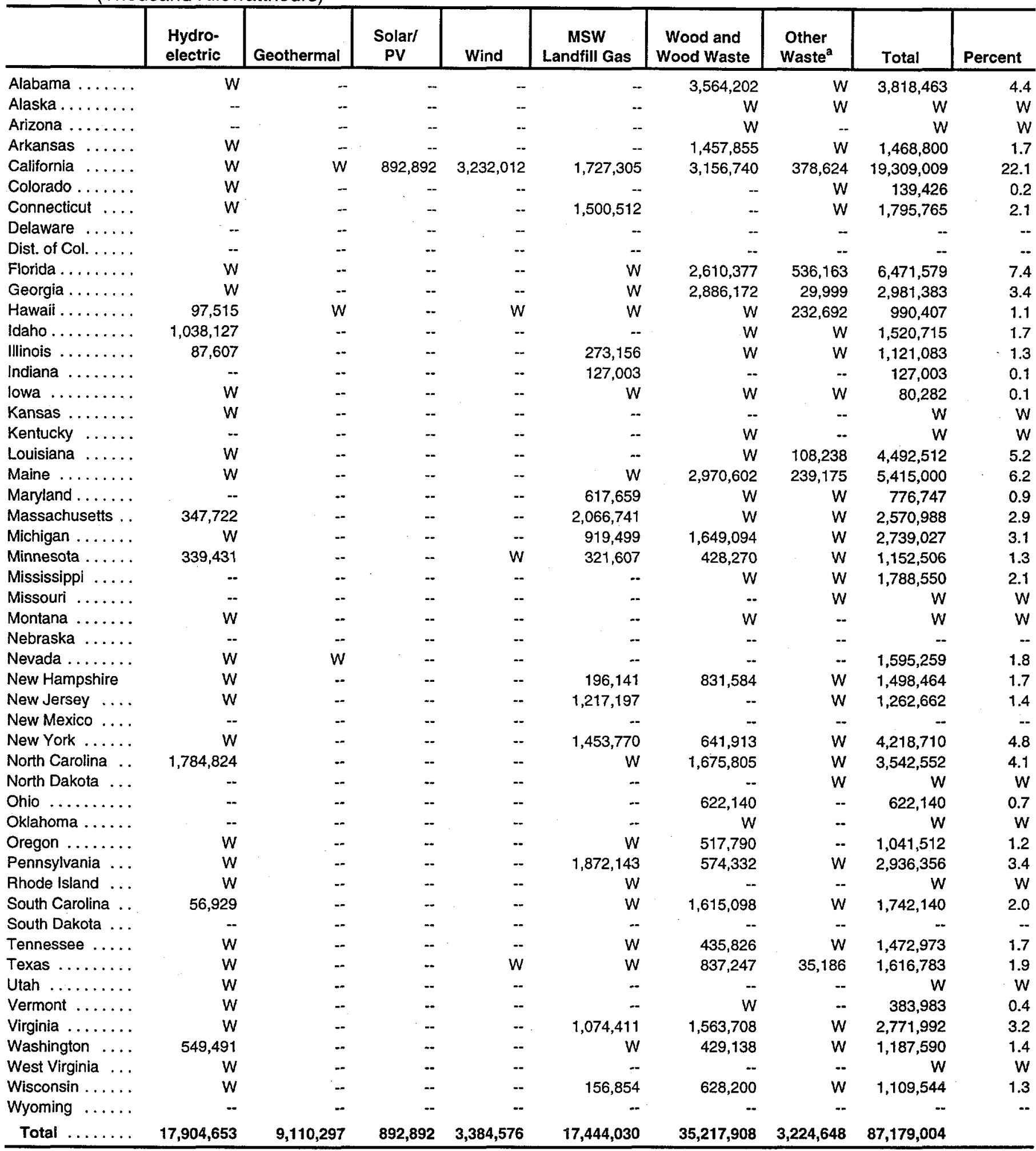

${ }^{a}$ Agricultural waste, straw, tires, fish oils, paper pellets, tall oil, sludge waste, and waste alcohol. --=Not applicable.

$\mathrm{W}=$ Data withheld to avoid disclosure of proprietary company data.

Note: Totals may not equal sum of components due to independent rounding.

Source: Energy Information Administration, Form EIA-867, "Annual Nonutility Power Producer Report." 
Table 7. U.S. Electric Generating Capacity, 1993-1997

(Megawatts)

\begin{tabular}{|c|c|c|c|c|c|}
\hline Source & 1993 & 1994 & 1995 & 1996 & 1997 \\
\hline Hydroelectric $^{a}$ & $\mathrm{R} 77,405$ & R78,042 & 78,563 & $\mathrm{R} 76,437$ & 79,795 \\
\hline Geothermal .. & 2,978 & 3,006 & 2,968 & $\mathrm{R} 2,893$ & 2,854 \\
\hline Biomass $\ldots \ldots \ldots$ & 10,045 & 10,465 & $R 10,263$ & $R 10,531$ & 10,702 \\
\hline Solar/Photovoltaic & 340 & 333 & 333 & 333 & 334 \\
\hline Wind $\ldots \ldots \ldots$ & 1,813 & 1,745 & $b_{1,731}$ & $\mathrm{R} 1,677$ & 1,620 \\
\hline Total Renewables & $\mathrm{R} 92,582$ & R93,591 & $\mathrm{R} 93,857$ & R91,868 & 95,303 \\
\hline Nonrenewables $^{c}$ & $\mathrm{R} 662,373$ & $\mathrm{R} 670,423$ & $\mathrm{R} 675,660$ & $R 684,004$ & 683,210 \\
\hline Total ........ & $\mathrm{R} 754,955$ & R764,014 & R769,517 & R775,872 & R778,513 \\
\hline
\end{tabular}

axcludes pumped storage, which is included in "Nonrenewables."

${ }^{b}$ Excludes 6.6 megawatts of utility capacity and 35 megawatts of nonutility capacity that were not captured by EIA sources.

'Includes hydrogen, sulfur, batteries, chemicals, spent sulfite liquor, and hydroelectric pumped storage.

$\mathrm{R}=$ Revised data.

Note: Capacity ratings for nonrenewables have been revised to reflect estimated net summer capability rather than nameplate capacity. The methodology for estimating net summer capability from reported nameplate capacity is presented in Energy Information Administration, Inventory of Power Plants in the United States as of January 1, 1997, DOE/EIA-0095(97), p. 286.

Sources: Energy Information Administration, Form ElA-860, "Annual Electric Generator Report," and Form ElA-867, “Annual Nonutility Power Producer Report."

\section{Biomass Energy}

U.S. biomass energy consumption declined sharply between 1996 and 1997, reflecting generally lower energy demand due to milder temperatures during the heating season. The industrial and residential sectors continued to represent the primary sectors of consumption (Table 8). However, a significant decline occurred in residential sector activity, based on new EIA survey information. ${ }^{7}$ A more moderate decrease in energy usage was observed in the industrial sector (Figure 2), where energy intensity is relatively fixed for given industries according to their manufacturing profiles.

\section{Wood, Wood Waste, and Energy Crops}

Table 9 lists residential woodburning activity by region in cord ${ }^{8}$ and Btu terms. Pellet fuel ${ }^{9}$ is consumed mainly in the residential and commercial sectors. The energy represented by pellet fuel consumption is embedded in the residential sector statistics presented here. The cornparison of pellet fuel statistics with overall residential sector wood consumption indicates:
- Pellet fuel consumption has grown to the extent that it now comprises about one-fourth of total residential woodburning.

- The regional pattern of pellet fuel sales and residential wood consumption are different (Figure 3 and Table 9).

- Pellet stove sales remained steady during the $1996 / 1997$ and $1997 / 1998$ heating seasons in spite of the overall decline in residential consumption (Figure 4).

Strong pellet sales in the Mountain and Pacific regions reflect the influence of strict environmental regulation. Industry literature indicates that growing sales in the Northeast are to a large extent due to more intensive recent marketing efforts. While the pellet industry is currently established on residential sales, it has stated expansion of sales to industrial customers to be an important industry goal.

Biomass cultivation for all purposes-food, energy, and feedstocks-is closely affected by weather. The 1990's, to date, have seen a number of significant weather events

7 Energy Information Administration, Residential Energy Consumption Survey 1994. Data for non-survey years is estimated by taking into consideration factors such as annual Heating Degree Days and other residential energy consumption characteristics.

8 By U.S. Forest Service convention, 1 cord $=128$ cubic feet in volume ( $4 \mathrm{ft} . \times 4 \mathrm{ft} . \times 8 \mathrm{ft}$.). By EIA convention, 1 cord contains the approximate equivalent of 20 million Btu.

9 Wood pellets are manufactured from finely ground wocid fiber. They are typically $1 / 4$ inch to $5 / 16$ inch in diameter by about $3 / 4$ inch in length and weigh more than 40 pounds per cubic foot. 
Table 8. Biomass Energy Consumption by Sector and Census Region, 1993-1997 (Trillion Btu)

\begin{tabular}{|c|c|c|c|c|c|}
\hline Energy Source & 1993 & 1994 & 1995 & 1996 & 1997 \\
\hline $\begin{array}{l}\text { Wood Energy } \\
\text { Sector }\end{array}$ & 2,228 & 2,266 & $\mathrm{R} 2,250$ & $\mathrm{R2,335}$ & 2,103 \\
\hline Residential . . . . . . . . . . . & 548 & 537 & 596 & 595 & 433 \\
\hline Commercial $\ldots \ldots \ldots \ldots \ldots$ & 44 & 45 & 45 & 49 & 42 \\
\hline Industrial $\ldots \ldots \ldots \ldots \ldots \ldots$ & 1,625 & 1,673 & $\mathrm{R} 1,598$ & $\mathrm{R} 1,679$ & 1,617 \\
\hline Electric Utility . . . . . . . . . & 11 & 11 & 11 & 12 & 11 \\
\hline \multicolumn{6}{|l|}{ Census Region } \\
\hline Northeast.............. & 277 & 278 & R343 & R348 & 328 \\
\hline Midwest . . . . . & 222 & 223 & R269 & R269 & 226 \\
\hline South $\ldots \ldots \ldots \ldots \ldots$ & 1,405 & 1,437 & $\mathrm{R} 1,024$ & $\mathrm{R} 1,074$ & 957 \\
\hline 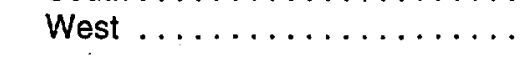 & 324 & 328 & $\mathrm{R} 615$ & R644 & 592 \\
\hline $\begin{array}{l}\text { Waste Energy }{ }^{b} \ldots \ldots \ldots \ldots \ldots \\
\text { Source }\end{array}$ & 468 & 475 & 492 & R529 & 523 \\
\hline Municipal Solid Waste . . . . . . . & 390 & 394 & 408 & R447 & 449 \\
\hline Combustion $\ldots \ldots \ldots \ldots \ldots$ & 318 & 323 & 333 & R359 & 359 \\
\hline Landfill Gas $\ldots \ldots \ldots \ldots \ldots$ & 72 & 71 & 75 & 88 & 90 \\
\hline Manufacturing $\ldots \ldots \ldots \ldots$ & 78 & 81 & 81 & 82 & 74 \\
\hline \multicolumn{6}{|l|}{ Census Region } \\
\hline Northwest ... & 151 & 171 & 173 & $\mathrm{R} 188$ & 191 \\
\hline Midwest .... . . & 85 & 76 & 88 & $\mathrm{R} 80$ & 88 \\
\hline South $\ldots \ldots \ldots \ldots \ldots \ldots$ & 130 & 134 & 134 & R158 & 151 \\
\hline West $\ldots \ldots \ldots \ldots \ldots \ldots$ & 102 & 95 & 96 & R103 & 93 \\
\hline $\begin{array}{l}\text { Alcohol Fuels (Ethanol) ........ } \\
\text { Census Region }\end{array}$ & 88 & 97 & 104 & 74 & 97 \\
\hline Northwest $\ldots \ldots \ldots \ldots \ldots$ & * & * & 3 & R7 & 9 \\
\hline Midwest $\ldots \ldots \ldots \ldots \ldots \ldots$ & 61 & 68 & 74 & R43 & 56 \\
\hline South $\ldots \ldots \ldots \ldots \ldots \ldots$ & 14 & 16 & 10 & R8 & 11 \\
\hline 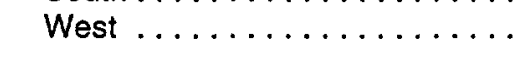 & 11 & 12 & 17 & R16 & 21 \\
\hline Biomass Energy Consumption .. & 2,784 & 2,838 & $\mathbf{R} 2, \mathbf{8 4 6}$ & $\mathbf{R} 2,938$ & 2,723 \\
\hline
\end{tabular}

${ }^{a}$ Assuming an average energy yield of 17 million Btu per ton.

${ }^{b}$ Municipal solid waste, manufacturing waste, refuse-derived fuel, and methane recovered from landfills.

* = Less than 0.5 trillion Btu.

Note: The annual season runs from April 1 through March 31.

Source: Energy Information Administration, Annual Energy Review 1997, DOE/EIA-0384(97) (Washington, DC, July 1998), Table 10.3.

including droughts; floods, damaging winds, and weather-connected phenomena such as forest fires resulting from extended drought. Planting and harvesting have been affected in some regions by drought or flood. Winter storms in the Northeast during the past year resulted in large-scale damage to trees, creating greater than expected supply of wood for energy.

Longer term phenomena come under the heading of climate events. Scientists are intensively studying cyclical climate events such as El Nino and La Nina. The effect of climate events on biomass and the resulting availability of biomass for energy in the United States is mixed. Scientific observation and modeling has only recently begun to estimate the U.S. regional effects of the El Nino/La Nina cycles.
While individual climate events have varying impacts on biomass availability, of greater interest is their collective influence over time. Information from the National Climate Data Center is instructive in this regard. Figure 5 illustrates the change in U.S. winter temperature normals observed during two 30-year periods of time. While this is not the only climate factor modeled, it is one that is significant to an analysis of biomass consumption for energy. The changes in winter temperature also help to explain the greater overall consumption of residential biomass energy in the Northeast and South regions (Table 9).

In the industrial sector, the largest biomass energy producer-the Pulp \& Paper Industry-marked the $200^{\text {th }}$ anniversary of the paper machine, but amid a trend of 
Figure 2. U.S. Biomass Energy Consumption by Major Sectors, 1993-1997

(Trillion Btu)

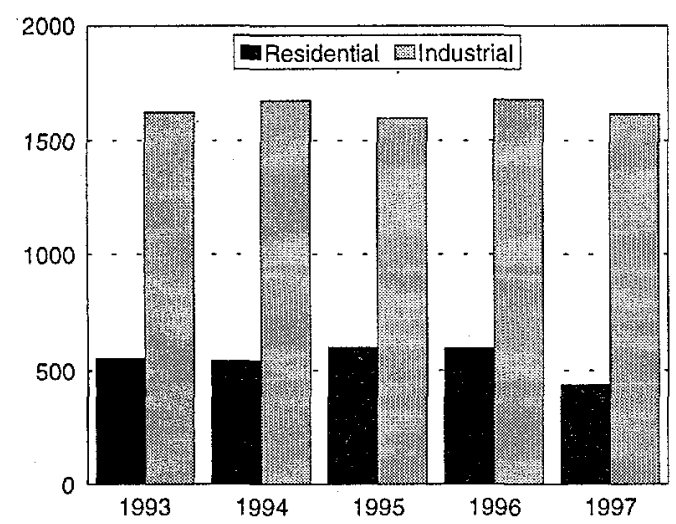

Source: Energy Information Administration, Annual Energy Review 1997, DOE/EIA-0384(97) (Washington, DC, July 1998), Table 10.3

lower rates of return on investment than other major industries. A pattern of consolidation and divestiture, according to individual corporate strengths and weaknesses, has developed in response, either along the primary resource or end-product specialization lines. Wholesale power marketing and management has also emerged as a very important factor of influence. Major changes in output and product mix have begun to take place in response to strongly increased activity in foreign primary fiber commodity exports to the United States. All these factors in combination are reshaping paper and forest products industries and promise to alter significantly the profile of national industrial biomass energy production.

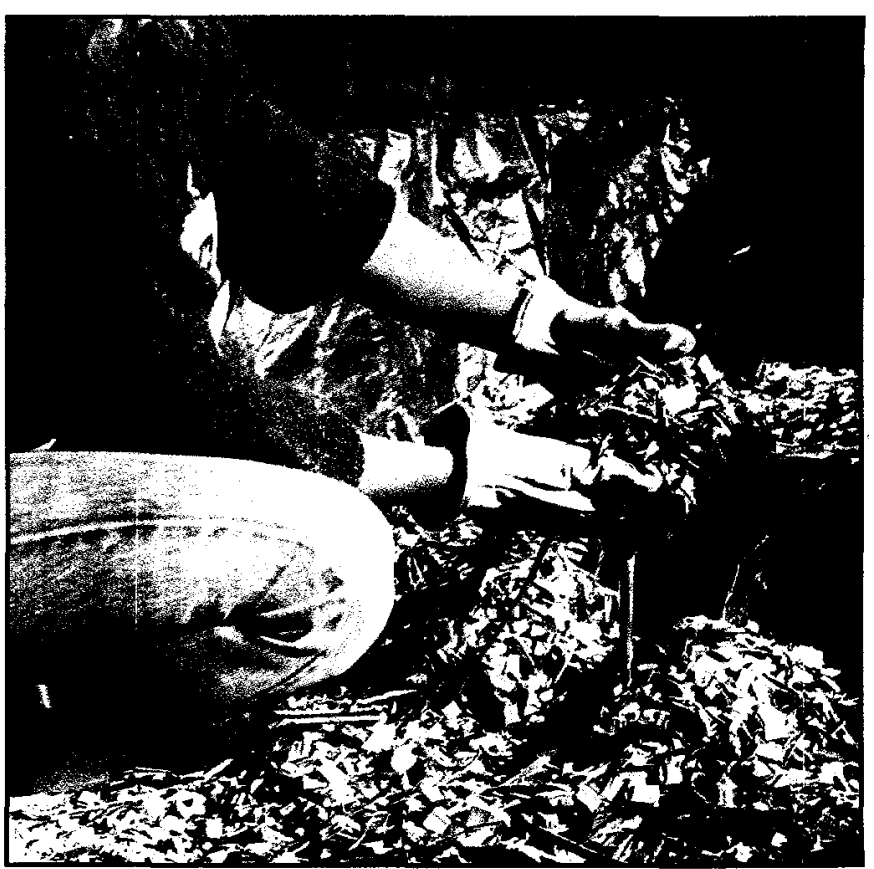

Aspen wood chips are being prepared for conversion to ethanol via the simultaneous saccharification and fermentation process.

\section{Municipal Solid Waste}

Energy consumption from municipal solid waste (MSW) grew from 390 trillion Btu in 1993 to 449 trillion Btu in 1997 (Table 8). Energy from MSW is obtained by both direct combustion (i.e., waste-to-energy) and from the recovery of landfill gas. Of the 449 trillion Btu of energy consumed from MSW in 1997, 359 trillion Btu were consumed by direct combustion and 90 trillion Btu were provided by landfill gas. Approximately 16 percent of all MSW tonnage generated in the United States is disposed of through direct combustion. ${ }^{10}$

Table 9. Residential Wood Energy Consumption, 1997

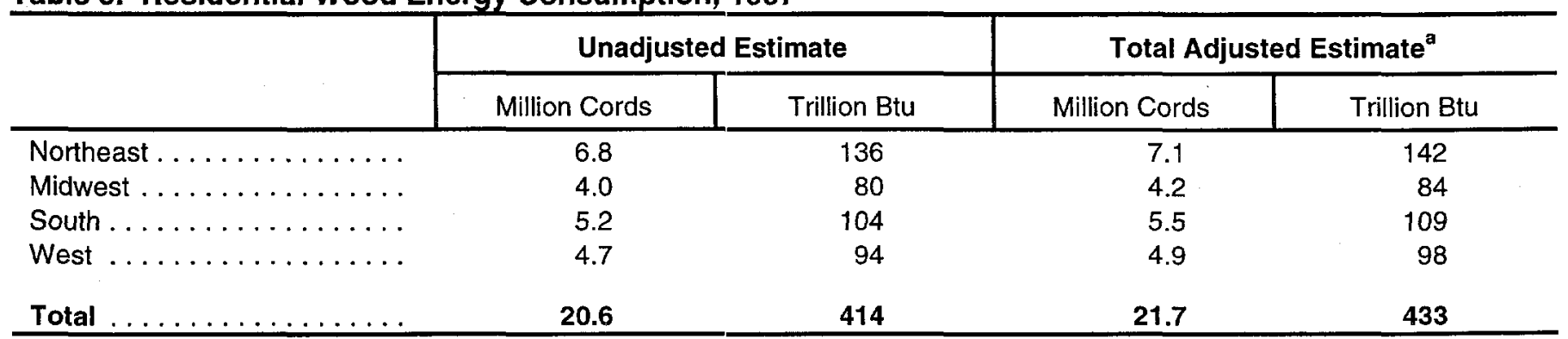

${ }^{a}$ Allows for wood burning in second homes.

Sources: Unadjusted estimate: Based on the Energy Information Administration, Residential Energy Consumption Survey 1993 and Office of Energy Markets and End Use estimates. Total adjusted estimates: Based on the Energy Information Administration, Office of Coal, Nuclear, Electric and Alternate Fuels estimates.

10 Governmental Advisory Associates, Inc., The Municipal Waste Combustion Industry In The United States-1997-98 Resource Recovery Yearbook and Directory (Westport, CT, 1997). 
Figure 3. Pellet Fuel Sales by Region, 1993-1998 (Thousand tons)

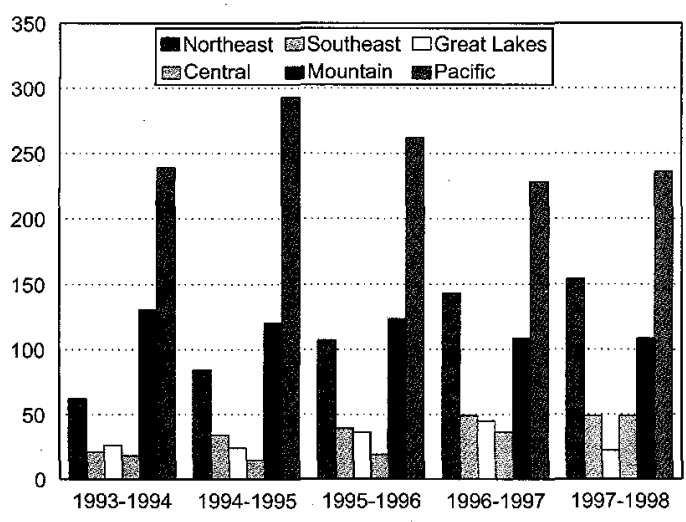

Source: Pellet Fuels Institute, PFI Newsletter, “June 1998 Market Update " (May/June 1998)

During 1997, approximately 107 waste-to-energy (WTE) facilities with a capacity to process over 100,000 tons per day were operating in the United States. About 80 percent of the projects generate electricity as the sole energy product or in conjunction with steam. The other 20 percent produce steam as the sole energy product (EIA does not collect information on steam-only facilities). The projects that generate electricity as the sole energy product or in conjunction with steam through direct combustion of MSW, have a generating capacity of approximately 2,600 megawatts, produced 16 million megawatthours of electricity in 1997, and consumed 280 trillion Btu.

Of the 133 landfill sites that recovered landfill gas in 1997, about 120 produce energy for generating facilities. These facilities have a combined generating capacity of around 832 megawatts. They produced 5 million megawatthours of electricity and consumed 42 trillion Btu of landfill gas. Facilities that burn MSW and landfill gas may also burn fossil fuels for start-up, fuel stabilization, or as a primary fuel.

The production of energy from municipal waste supplies grew very rapidly during the 1980 s, largely as a result of public policy at the Federal, State, and local level that promoted the construction of WTE facilities. Virtually all electricity generated by facilities that burn MSW or landfill gas are designated as "qualifying facilities" (QF) by the Public Utility Regulatory Policies Act of 1978 (PURPA). Under PURPA, electric utilities are required to purchase power generated by QFs at the "avoided cost" of the purchasing utility. The average price per kilowatthour received by MSW and landfill gas projects is dropping as contracts are renegotiated, because the
Figure 4. Pellet Fuel Appliance Sales, 1993-1998

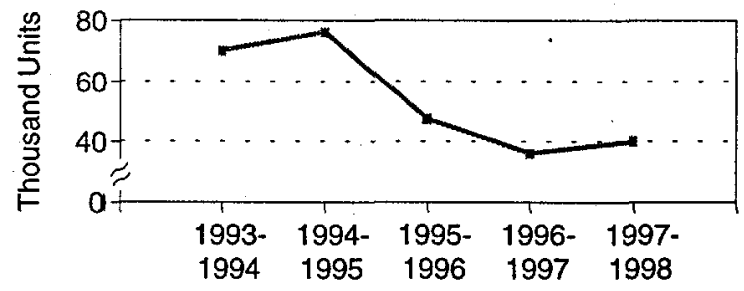

Source: Pellet Fuels Institute, PFI Newsletter, "June 1998 Market Update" (May/June 1998).

avoided cost received for electricity from new facilities is now based on competitive fuel prices. As power sales contracts negotiated in the 1980s between QFs and utilities expire, downward pressure on energy revenues will continue. A number of electric deregulation proposals include the elimination of PURPA.

Figure 5. Change in Winter Temperature Normals (1961-1990 minus 1931-1960)

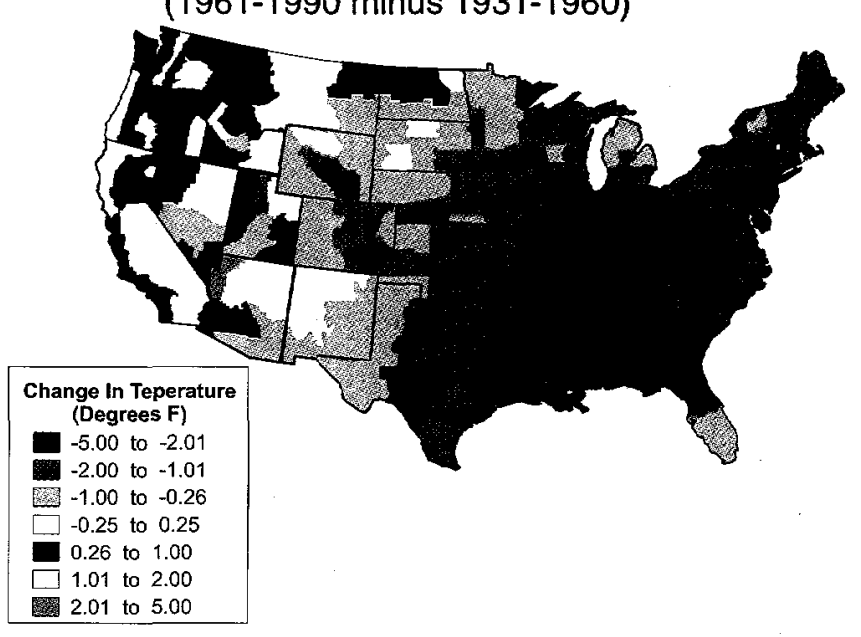

Source: Personal communication with Richard Heim, National Climate Data Center, National Oceanic and Atmospheric Administration, September 1998.

The growth in MSW projects has been dramatically curtailed during the 1990s, with a number of smaller, inefficient projects being retired. Today, environmental policies are encouraging recycling to reduce the quality and quantity of waste streams to WTE facilities, as well as requiring costly pollution control at these facilities. Federal tax policy no longer favors investments in capital intensive products and limits the amount of municipal bonds States can issue for the construction of facilities that are privately owned. As is the case with many industries in the United States, the waste-toenergy industry is also feeling the competitive pressures of deregulation. Electricity prices are dropping, resulting 
in waste streams going to the cheapest disposal option, often out-of-State landfills.

\section{Geothermal Energy}

Total geothermal energy consumption dropped 9 percent in 1997 to 0.322 quads. Virtually all ( 97 percent) of geothermal energy was used to generate electricity. Of the remaining 0.016 quads, nearly two-thirds $(0.010$ quads) drove geothermal or "ground water" heat pumps, with the balance used in low-temperature industrial and agricultural applications such as crop drying.

Over 60 percent of domestic geothermal energy consumption for electricity generation (0.306 quads) is consumed in the industrial sector, principally by "nonutilities." This percentage may rise in the future, as at least one California utility is planning to divest itself of its geothermal electricity plants. Except for a single plant in Nevada and a small amount of production in Hawaii, all domestic geothermal energy is produced in California.

Industrial consumption declined 11 percent in 1997, in contrast to a 5-percent increase in utility geothermal consumption. Industrial geothermal consumption has remained stagnant since 1993, compared with a decline of 27 percent in utility geothermal consumption. Several older geothermal fields in California have been depleted beyond their economically useful life and will likely not resume operation. Imported geothermal electricity from Mexico was virtually zero in 1997, compared with 0.014 quads in 1996. Geothermal electricity generation followed the patterns of energy consumption during 1996 and 1997.

Direct use of geothermal energy is either process heat for industrial applications or energy used to heat and cocil water for air temperature moderation applicationsi, using heat pumps. EIA does not collect information on direct geothermal energy but rather uses information provided under contract to the Department of Energy's Office of Energy Efficiency and Renewable Energy by the Oregon Institute of Technology's Geo-Heat Center. ${ }^{.1}$

\section{Wind Energy}

Between 1993 and 1997, wind electric generating capacity decreased about 193 megawatts to 1,620

11 See the website at http://www.oit.edu/admin/geohear/

12 Windpower Monthly (June 1998), pp. 31-33. megawatts, as retirements exceeded additions. Some additions for 1997 included a few small projects that partially offset the decline:

- Kotzebue, Alaska (0.15 megawatts)

- Pacheco Pass, California (16 megawatts)

- Sibley, Iowa (1.2 megawatts)

- Searsburg, Vermont (6 megawatts).

Although capacity has declined over the past 5 years, improved efficiency has resulted in increased generation from wind-up some 12 percent over the period. Total wind energy consumption was 35 trillion Btu in 1997-an increase of 4 trillion Btu since 1993 (Figure 6).

Figure 6. Wind Energy Consumption, 1993-1997

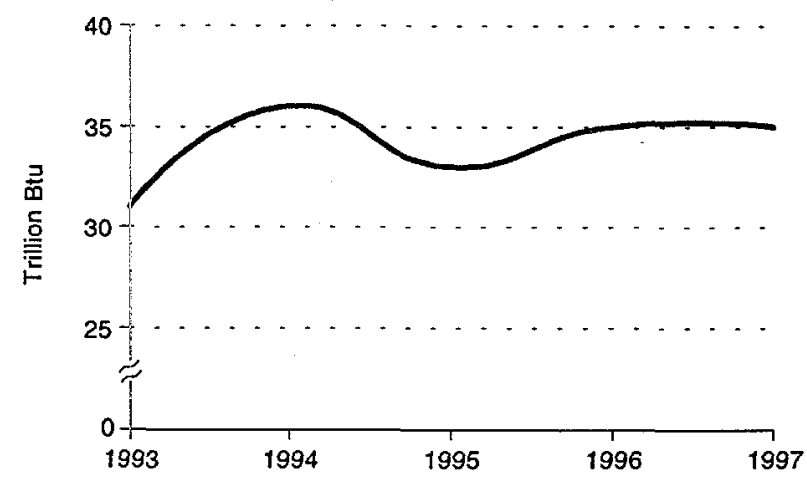

Sources: Energy Information Administration, Form EIA-759, "Monthly Power Plant Report"; Form EIA-867, "Annual Nonutility Power Producer Report."

Indications are that 1998 will be a very active year for construction. In July 1998, capacity expanded considerably, as the Phase II 107-megawatt Lake Benton, Minnesota project came on line. Other future developments include the following within the next 1 to 2 years: ${ }^{12}$

- California (approximately 281 megawatts to be repowered statewide)

- Buena Vista County, Iowa (112.5 megawatts)

- Clear Lake, Iowa (42 megawatts)

- Storm Lake, Iowa (75 megawatts) 


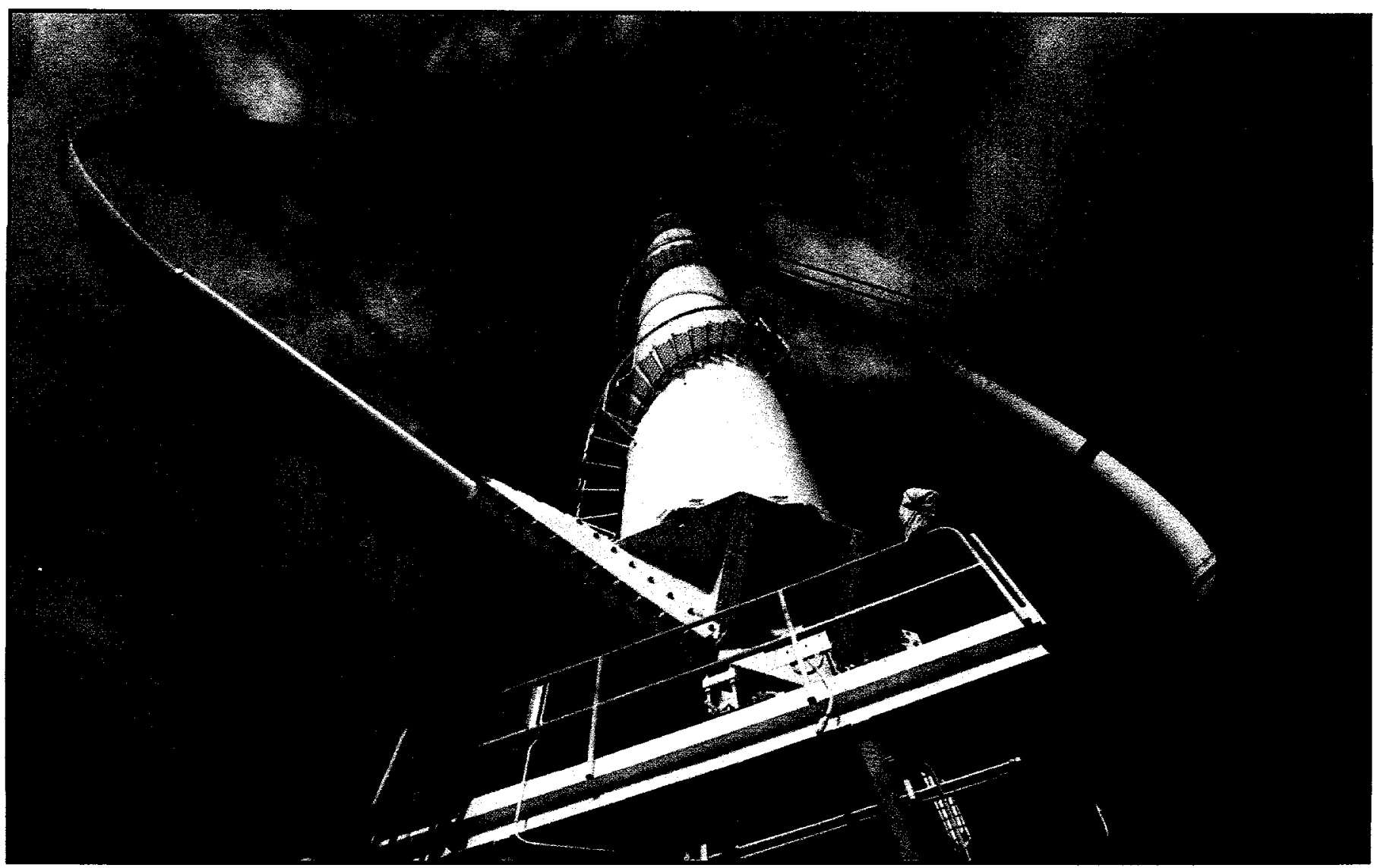

The $500 \mathrm{~kW}, 34 \mathrm{M}$ diameter Vertical Axis Wind Turbine (VAWT) Test Bed Located at Bushland, Texas.

- Pipestone County, Minnesota (Phase III, 103.5 megawatts)

- Vansycle, Oregon (24.9 megawatts)

- Big Spring, Texas (34.8 megawatts)

- McCamey, Texas (75 megawatts)

- Foot Creek Rim, Wyoming (41.4 megawatts).

Two key factors are driving this flurry of construction activity: (1) State mandates, as in the case of Minnesota and Iowa; and (2) the nationwide rush to beat the expiration of the 1.5 cent-per-kilowatthour production tax credit offered until June 1999, pending passage of legislation for an extension. Among the companies involved in this construction, Zond Systems, Inc. is the most active with commitments of nearly 300 megawatts, using the new Z-750 series of turbines. It is followed by Seawest with about 80 megawatts committed, the FPL Group, and York Corporation.

\section{Solar Energy}

Although higher in 1997 than in 1993, solar energy consumption declined 1 percent to 74 trillion Btu between 1996 and 1997. Most of this was in the residential and commercial sector, where some older equipment reached the end of its useful life of 20 years. Most gridconnected solar electricity generation occurs at nonutility facilities, where generation decreased slightly in 1997 to 893 million kilowatthours. Utility solar generation increased over the same period, but at 3.5 million kilowatthours it remains a negligible share of total renewable generation. Ninety-four percent was generated in California (Table 10). 
Table 10. U.S. Utility Net Electric Generation from Solar Energy, 1997 (Thousand Kilowatthours)

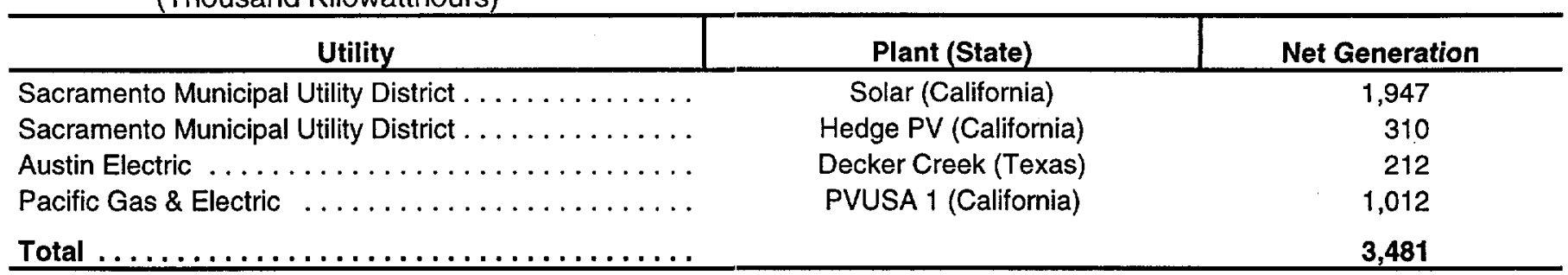

Note: Net generation is gross generation minus plant use.

Source: Energy Information Administration, Electric Power Monthly May 1998, DOE/EIA-0226(98/05) (Washington, DC, May 1998), Table 58. 


\section{Solar Thermal and Photovoltaic Collector Manufacturing Activities}

\section{Introduction}

This chapter presents national and State-level data on the United States solar thermal collector and photovoltaic module and cell manufacturing industry. The data are reported to the EIA by U.S.-based manufacturers and importers of solar equipment on Forms EIA-63A, "Annual Solar Thermal Collector Manufacturers Survey," and EIA-63B, "Annual Photovoltaic Module/Cell Manufacturers Survey." Historical data for comparison are presented for annual domestic shipments of solar thermal collectors during 1978 through 1997 and for photovoltaic cells and modules during 1982 through 1997 (Table 11).

Since 1978, domestic manufacturers have shipped 227,177 square feet of solar thermal collectors. The total number of domestic shipments in peak kilowatts of photovoltaic cells and modules since 1982 is 114,858 peak kilowatts. Solar collectors are estimated to have a useful life of 20 years. Throughout the chapter, the unit of measure is square feet of collector surface for solar thermal collectors and peak kilowatts for photovoltaic cells and modules.

\section{Collector Type Descriptions}

Solar thermal collectors are divided into the categories of low-, medium-, and high-temperature collectors. Low-temperature collectors provide heat up to $110^{\circ}$ Fahrenheit through either metallic or nonmetallic absorbers and are used in applications such as swimming pool heating, and water, space, and process heating. Medium-temperature collectors provide heat greater than $110^{\circ}$ Fahrenheit (usually 140 to $180^{\circ}$ Fahrenheit) through either glazed flat-plate collectors that use air or liquid as the heat transfer medium or concentrator collectors that concentrate the heat of incident insolation to greater than "one sun"-essentially unobstructed, normal sunlight. Evacuated-tube collectors are included in this category. High-temperature collectors are parabolic dish and trough collectors and are used primarily by utilities and nonutility power producers in the generation of electricity for the grid. A hightemperature solar thermal collector operates at temperatures above 180 degrees Fahrenheit.

Table 11. Annual Photovoltaic and Solar Thermal Shipments, 1978-1997

\begin{tabular}{c|c|c}
\hline \multirow{2}{*}{} & \multicolumn{2}{|c}{ Domestic Shipments } \\
\cline { 2 - 3 } Year & $\begin{array}{c}\text { a } \\
\text { Photovoltaic Cells } \\
\text { and Modules } \\
\text { (Peak Kilowatts) }\end{array}$ & $\begin{array}{c}\text { Solar Thermal } \\
\text { Collectors } \\
\text { (Thousand } \\
\text { Square Feet) }\end{array}$ \\
\hline $1978 \ldots \ldots$ & - & 10,020 \\
$1979 \ldots \ldots$ & - & 13,396 \\
$1980 \ldots \ldots$ & - & 18,283 \\
$1981 \ldots \ldots$ & - & 19,362 \\
$1982 \ldots \ldots$ & 6,897 & 18,166 \\
$1983 \ldots \ldots$ & 10,717 & 16,669 \\
$1984 \ldots \ldots$ & 7,759 & 16,843 \\
$1985 \ldots \ldots$ & 4,099 & $b^{1} \ldots, 166$ \\
$1986 \ldots \ldots$ & 3,224 & 9,136 \\
$1987 \ldots \ldots$ & 3,029 & 7,087 \\
$1988 \ldots \ldots$ & 4,318 & 8,016 \\
$1989 \ldots \ldots$ & 5,462 & 11,021 \\
$1990 \ldots \ldots$ & 6,293 & 11,164 \\
$1991 \ldots \ldots$ & 6,035 & 6,242 \\
$1992 \ldots \ldots$ & 5,760 & 6,770 \\
$1993 \ldots \ldots$ & 6,137 & 6,557 \\
$1994 \ldots \ldots$ & 8,363 & 7,222 \\
$1995 \ldots \ldots$ & 11,188 & 7,136 \\
$1996 \ldots \ldots$ & 13,016 & 7,162 \\
$1997 \ldots \ldots$ & 12,561 & 7,759 \\
Total $\ldots \ldots$ & 114,858 & 227,177 \\
\hline
\end{tabular}

a Total shipments minus export shipments.

Estimated data.

$-=$ Not available.

Sources: 1978-1984: Energy Information Administration, Form EIA-63, "Annual Solar Thermal Collector and Photovoltaic Module Manufacturers Survey." 1985-1997: Energy Information Administration, Form ElA-63A, "Annual Solar Thermal Collector Manufacturers Survey," and Form EIA-63B, "Annual Photovoltaic Module/Cell Manufacturers Survey." 


\section{Solar Thermal Activities}

\section{Shipments}

Solar thermal collector shipments totaled 8.1 million square feet in 1997, an increase of 7 percent from the 1996 level of 7.6 million square feet (Table 12). Import shipments totaled 2.1 million square feet, while export shipments were 0.4 million square feet in 1997 (Figure 7). Shipments of low-temperature solar thermal collectors increased to 7.5 million square feet in 1997, compared to 6.8 million square feet in 1996 (Table 13). Shipments of medium-temperature collectors decreased 22 percent to 0.61 million square feet in 1997 from 0.79 million square feet in 1996. This is a continuation of a long-term decline in medium-temperature collector production. Shipments of high-temperature collectors decreased to 7,000 square feet in 1997 from 10,000 square feet in 1996.

\section{Origins}

U.S. manufacturers in five States-California, New York, New Jersey, Florida, and Hawaii-produced 98 percent of U.S.-manufactured collectors in 1997 (this represents only shipments manufactured in the United States). In 1996, four States-California, Florida, New Jersey, and New York-and Puerto Rico-produced 98 percent (Table 14). California continued to lead the United States with 38 percent of total domestic shipments in 1997, an increase from 33 percent in 1996 (Table 14). New Jersey, Florida, New York, and Hawaii shipped a combined 3.6 million square feet in 1997.
Figure 7. Import and Export Shipments of Solar Thermal Collectors, 1987-1997

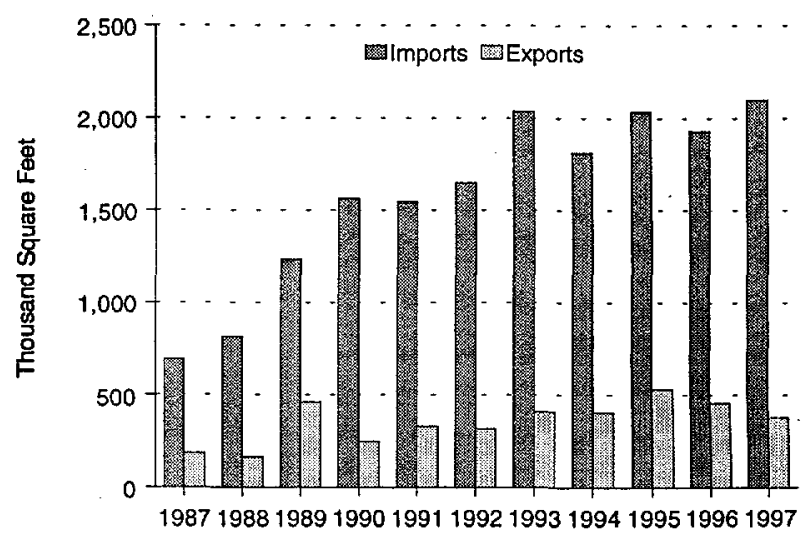

Notes: Total shipments as reported by respondents include all domestic and export shipments and may include imports that subsequently were shipped to domestic or foreign customers.

Source: 1987-1997: Energy Information Administration, Form EIA-63A, "Annual Solar Thermal Collector Manufacturers Survey."

\section{Destinations}

\section{Domestic}

Nearly half of solar collector volume shipped went to Florida in both 1996 and 1997. Solar thermal collectors

Table 12. Annual Shipments of Solar Thermal Collectors, 1987-1997

\begin{tabular}{|c|c|c|c|c|c|}
\hline \multirow{2}{*}{\multicolumn{2}{|c|}{ Year }} & \multirow[b]{2}{*}{ Number of Companies } & \multicolumn{3}{|c|}{ Collector Shipments (thousand square feet) ${ }^{\mathrm{a}}$} \\
\hline & & & Total & Imports & Exports \\
\hline 1987 & & 59 & 7,269 & 691 & 182 \\
\hline 1988 & $\ldots \ldots \ldots \ldots$ & 51 & 8,174 & 814 & 158 \\
\hline 1989 & $\ldots \ldots \ldots \ldots$ & 44 & 11,482 & 1,233 & 461 \\
\hline 1990 & 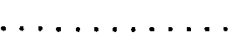 & 51 & 11,409 & 1,562 & 245 \\
\hline 1991 & $\ldots \ldots \ldots \ldots \ldots$ & 48 & 6,574 & 1,543 & 332 \\
\hline 1992 & $\ldots \ldots \ldots \ldots$ & 45 & 7,086 & 1,650 & 316 \\
\hline 1993 & $\ldots \ldots \ldots \ldots \ldots$ & 41 & 6,968 & 2,039 & 411 \\
\hline 1994 & $\ldots \ldots \ldots$ & 41 & 7,627 & 1,815 & 405 \\
\hline 1995 & $\cdots \ldots{ }_{1}$ & 36 & 7,666 & 2,037 & 530 \\
\hline 1996 & $\ldots \ldots \ldots \ldots \ldots$ & 28 & 7,616 & 1,930 & 454 \\
\hline 1997 & & 29 & 8,138 & 2,102 & 379 \\
\hline
\end{tabular}

ancludes imputation of shipment data to account for nonrespondents.

Note: Total shipments as reported by respondents include all domestic and export shipments and may include imported collectors that subsequently were shipped to domestic or foreign customers.

Source: Energy Information Administration, Form EIA-63A, "Annual Solar Thermal Collector Manufacturers Survey." 
Table 13. Annual Shipments of Solar Thermal Collectors by Type, 1987-1997 (Thousand Square Feet)

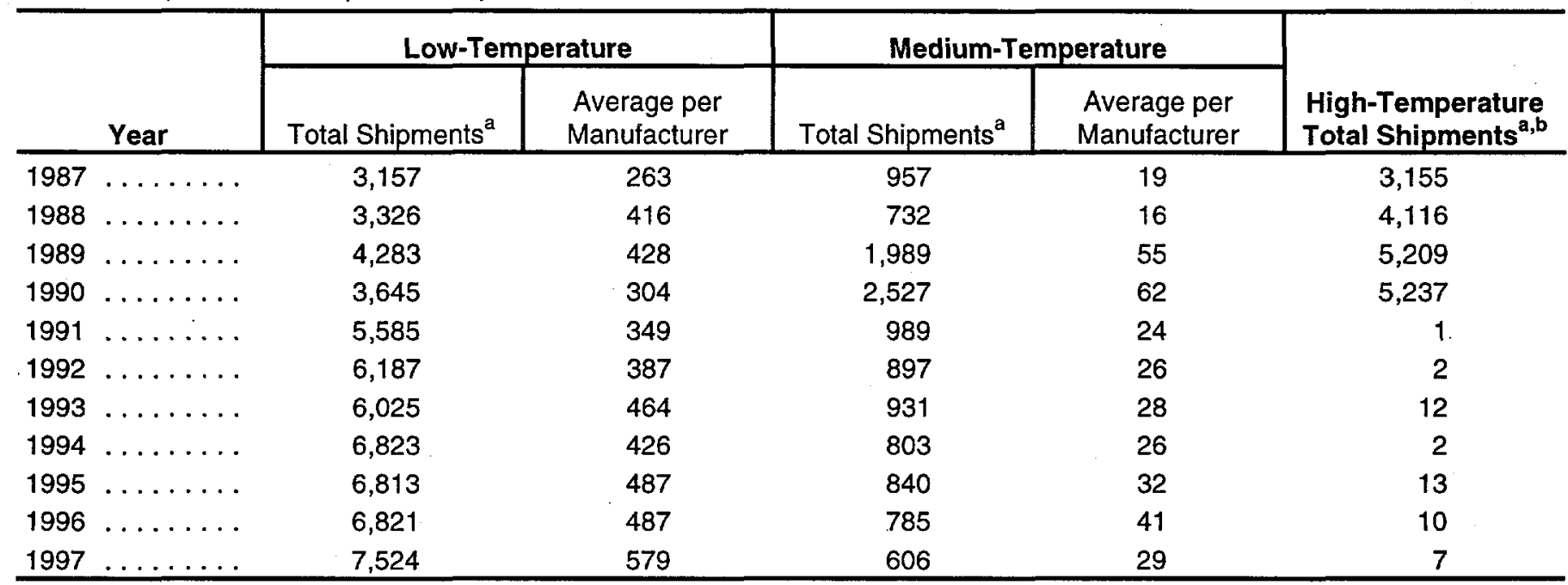

ancludes imputation of shipment data to account for nonrespondents.

${ }^{b}$ For high-temperature collectors, average annual shipments per manufacturer are not disclosed.

Source: Energy Information Administration, Form EIA-63A, "Annual Solar Thermal Collector Manufacturers Survey."

Table 14. Shipments of Domestic Solar Collectors Ranked by Top Five Origins and Destinations, 1996 and 1997

\begin{tabular}{|c|c|c|c|c|}
\hline \multirow[b]{2}{*}{ Origin/Destination } & \multicolumn{2}{|c|}{1996 Shipments } & \multicolumn{2}{|c|}{1997 Shipments } \\
\hline & $\begin{array}{l}\text { Thousand } \\
\text { Square Feet }\end{array}$ & $\begin{array}{l}\text { Percent of } \\
\text { U.S. Total }\end{array}$ & $\begin{array}{l}\text { Thousand } \\
\text { Square Feet }\end{array}$ & $\begin{array}{l}\text { Percent of } \\
\text { U.S. Total } \\
\end{array}$ \\
\hline \multicolumn{5}{|l|}{ Origin $^{a}$} \\
\hline California $\ldots \ldots \ldots \ldots \ldots \ldots \ldots$ & 1,819 & 33 & 2,308 & 38 \\
\hline Florida $^{b} \ldots$ & 683 & 12 & NA & NA \\
\hline New Jersey, New York and Puerto Rico ${ }^{b} \ldots \ldots \ldots$ & 2,905 & 53 & NA & NA \\
\hline Top Five Total $\ldots \ldots \ldots \ldots \ldots \ldots \ldots$ & 5,406 & 98 & 5,921 & 98 \\
\hline \multicolumn{5}{|l|}{ Destination $^{d}$} \\
\hline Florida $\ldots \ldots \ldots \ldots \ldots \ldots \ldots \ldots$ & 3,519 & 49 & 3,975 & 49 \\
\hline California . . . . . . . . . . . . . . . & 1,472 & 21 & 1,781 & 22 \\
\hline New York ${ }^{b} \ldots \ldots \ldots \ldots \ldots \ldots \ldots \ldots$ & 219 & 3 & NA & NA \\
\hline Top Five Total $\ldots \ldots \ldots \ldots \ldots \ldots \ldots \ldots$ & 5,850 & 82 & 6,605 & 81 \\
\hline
\end{tabular}

${ }^{a}$ Represents only shipments manufactured in the United States.

bData for these states are for 1996 only.

'Data for these states are for 1997 only.

${ }^{\mathrm{d}}$ Based on the total shipped each year to the United States and Territories.

$\mathrm{NA}=$ Not available.

Notes: Totals may not equal sum of components due to independent rounding. U.S. total includes territories.

Source: Energy Information Administration, Form EIA-63A, "Annual Solar Thermal Collector Manufacturers Survey." 
were shipped to 41 States, Puerto Rico, and the U.S. Virgin Islands in 1997 (Table 15). The five States that received the largest amounts of total solar thermal collector shipments in 1997 were: Florida (49 percent), California (22 percent), Arizona (6 percent), Hawaii (3 percent), and Oregon (2 percent) (Table 14). All of the collectors manufactured in Puerto Rico remained on the island. The U.S. market for solar thermal collectors continued to be highly concentrated in a few States and Puerto Rico. Factors favorable for solar energy use in these States and Puerto Rico are: (1) good solar insolation,; (2) high electricity costs; (3) solar-promoting incentives, such as tax credits or exemptions; and (4) a demand for low technology solar pool heaters and solar domestic hot water systems.

\section{Export}

Exports accounted for 5 percent of total shipments in 1997. A total of 11 companies exported solar thermal collectors in 1997 compared with 19 companies in 1996. Of total 1997 exports, 5 companies exported low-temperature collectors and 10 exported medium-temperature collectors. Regionally, the largest percentage of shipments were to North and South America ( 40 percent), followed by Europe and the Middle East ( 37 percent) and Asia (23 percent) (Table 16). Trading countries that received the most export shipments were Canada (22 percent), Taiwan (15 percent), Sweden (12 percent), Germany ( 8 percent), Korea ( 7 percent), Austria ( 6 percent), Guatemala and Belgium (both 4 percent).

Table 15. Shipments of Solar Thermal Collectors by Destination, 1997 (Square Feet)

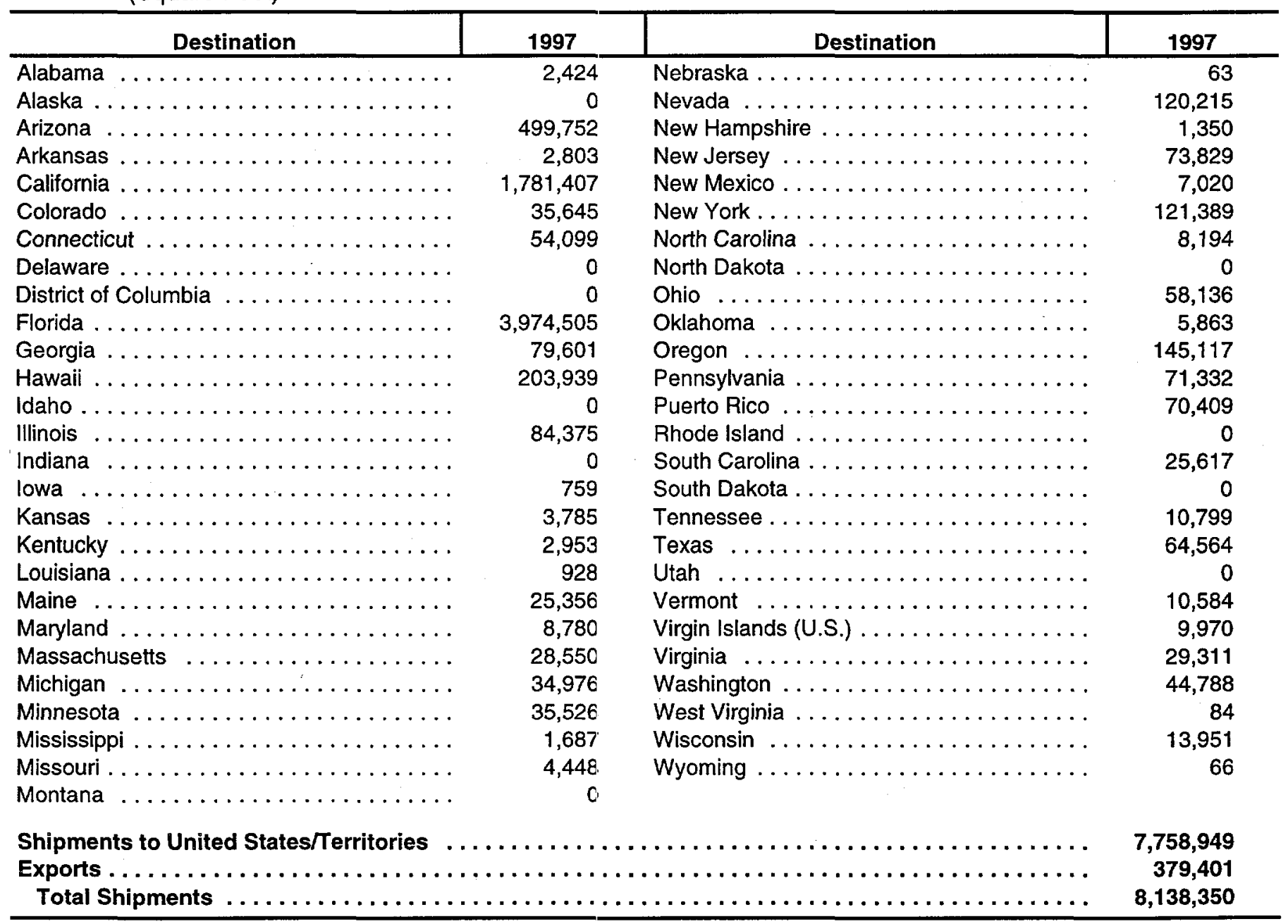

Source: Energy Information Administration, Form ElA-63,A, "Annual Solar Thermal Collector Manufacturers Survey.”

13 Insolation refers to the amount of solar radiation reaching the earth unobstructed. 
Table 16. Distribution of U.S. Solar Thermal Collector Exports by Country, 1997

\begin{tabular}{|c|c|}
\hline Country & $\begin{array}{c}\text { Percent of } \\
\text { U.S. Exports }\end{array}$ \\
\hline \multicolumn{2}{|l|}{ Asia } \\
\hline$\ldots \ldots \ldots \ldots \ldots$ & 0.9 \\
\hline India $\ldots \ldots \ldots \ldots \ldots \ldots$ & 0.1 \\
\hline Japan $\ldots \ldots \ldots \ldots \ldots$ & 0.2 \\
\hline Korea $\ldots \ldots \ldots \ldots \ldots \ldots$ & 7.3 \\
\hline Taiwan ................. & 14.5 \\
\hline Total $\ldots \ldots \ldots \ldots \ldots \ldots$ & 23.0 \\
\hline \multicolumn{2}{|l|}{ Europe and Middle East } \\
\hline Austria $\ldots \ldots \ldots \ldots \ldots \ldots$ & 6.0 \\
\hline Belgium $\ldots \ldots \ldots \ldots \ldots \ldots$ & 4.1 \\
\hline Denmark .............. & 1.5 \\
\hline France $\ldots \ldots \ldots \ldots \ldots \ldots$ & 0.4 \\
\hline Germany ............... & 8.3 \\
\hline 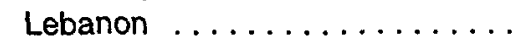 & 1.1 \\
\hline Spain . . . . . . . . . . . . & 1.8 \\
\hline Sweden $\ldots \ldots \ldots \ldots \ldots \ldots$ & 11.9 \\
\hline Switzerland $\ldots \ldots \ldots \ldots \ldots$ & 1.4 \\
\hline Turkey ................. & 0.2 \\
\hline Total $\ldots \ldots \ldots \ldots \ldots$ & 36.7 \\
\hline \multicolumn{2}{|l|}{ The Americas } \\
\hline Antigua $\ldots \ldots \ldots \ldots \ldots$ & 0.5 \\
\hline Aruba $\ldots \ldots \ldots \ldots \ldots$ & 0.2 \\
\hline Bahamas . . . . . . . . . . & 1.1 \\
\hline Belize $\ldots \ldots \ldots \ldots \ldots \ldots \ldots$ & 0.1 \\
\hline Bermuda . . . . . . . . . . . & 0.1 \\
\hline Bolivia . . . . . . . . . . . . & 0.1 \\
\hline Bonaire $\ldots \ldots \ldots \ldots \ldots \ldots$ & 0.2 \\
\hline British Virgin Islands $\ldots \ldots \ldots \ldots$ & 0.4 \\
\hline Canada $\ldots \ldots \ldots \ldots \ldots$ & 21.8 \\
\hline Caribbean $\ldots \ldots \ldots \ldots \ldots$ & 3.4 \\
\hline Chile $\ldots \ldots \ldots \ldots \ldots \ldots$ & 1.5 \\
\hline Costa Rica . . . . . . . . . . . . & 0.6 \\
\hline Ecuador $\ldots \ldots \ldots \ldots \ldots$ & 0.6 \\
\hline Guatemala .............. & 4.0 \\
\hline Honduras . . . . . . . . . . . . & 0.7 \\
\hline Jamaica . . . . . . . . . . . & 0.5 \\
\hline Mexico ................. & 3.7 \\
\hline St. Martin . . . . . . . . . . . . & 0.1 \\
\hline St. Vincent $\ldots \ldots \ldots \ldots \ldots \ldots$ & 0.3 \\
\hline Trinidad $\ldots \ldots \ldots \ldots \ldots \ldots$ & 0.2 \\
\hline Total $\ldots \ldots \ldots \ldots \ldots \ldots$ & 40.1 \\
\hline Total .... & 100.0 \\
\hline
\end{tabular}

Notes: Totals may not equal sum of components due to independent rounding.

Source: Energy Information Administration, Form EIA-63A, "Annual Solar Thermal Collector Manufacturer Survey."

\section{Distribution}

Of total shipments in 1997, 55 percent were sent directly to wholesale distributors and 31 percent were sent to retail distributors (Table 17). Direct shipments to exporters, installers, end users, and others accounted for 15 percent of total shipments in 1997.

\section{Table 17. Distribution of Solar Thermal Collector Shipments, 1996 and 1997}

\begin{tabular}{|c|c|c|}
\hline \multirow[b]{2}{*}{ Recipient } & \multicolumn{2}{|c|}{$\begin{array}{l}\text { Shipments } \\
\text { (thousand square feet) }\end{array}$} \\
\hline & 1996 & 1997 \\
\hline Wholesale Distributors . . . . . & 4,843 & 4,446 \\
\hline Retail Distributors ....... & 1,655 & 2,491 \\
\hline Exporters . . . . . . . . . & 372 & 417 \\
\hline Installers $\ldots \ldots \ldots \ldots \ldots$ & 529 & 585 \\
\hline End Users and Other ${ }^{a} \ldots \ldots$ & 217 & 199 \\
\hline Total $\ldots \ldots \ldots \ldots$ & 7,616 & 8,138 \\
\hline \multicolumn{3}{|c|}{$\begin{array}{l}\text { aOther includes minimal shipments not explained on Form } \\
\text { EIA-63A. } \\
\text { Note: Totals may not equal sum of components due to } \\
\text { independent rounding. } \\
\text { Source: Energy Information Administration, Form EIA-63A, } \\
\text { "Annual Solar Thermal Collector Manufacturers Survey." }\end{array}$} \\
\hline
\end{tabular}

\section{Collector Types}

From 1988 through 1997, annual shipments of low-temperature collectors ranged between 3.3 and 7.5 million square feet (Figure 8). In 1997, medium-temperature collector manufacturers shipped just under 0.6 million square feet, a decrease of 23 percent from 1996.

Low-temperature collectors dominated the solar thermal industry in 1997, accounting for 92.5 percent of total shipments (Table 18). Medium-temperature collectors accounted for 7.5 percent of total collector shipments in 1997. About 85 percent of these were flat plate collectors. Those that constituted subunits of thermosiphon systems or integral collector storage systems (ICS) represented 0.4 percent of total shipments. Hightemperature collectors, shipped primarily for research and demonstration projects, represented about 0.1 percent of total shipments in 1997. 
Figure 8. Solar Thermal Collector Shipments by Collector Type, 1986-1997

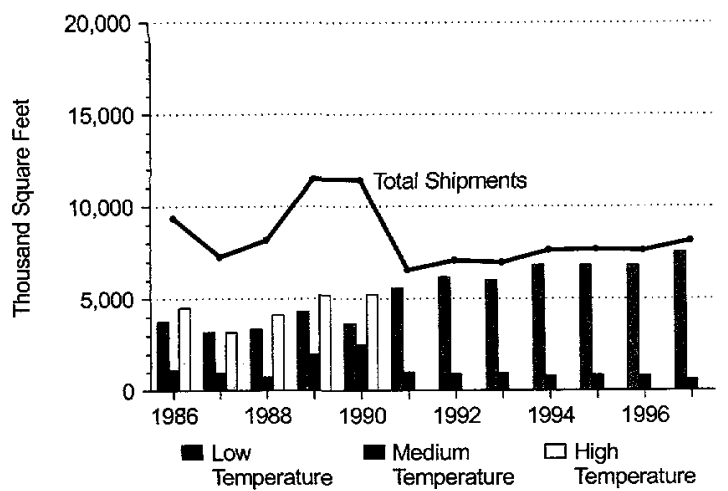

Source: Energy Information Administration, Form EIA-6\$A, "Annual Solar Thermal Collector Manufacturers Survey."

\section{Values and Prices}

The total value of solar thermal collector shipments was $\$ 29$ million in 1997, a 3-percent decrease compared with 1996. The average price (in dollars per square foot) of low-temperature collectors decreased to $\$ 2.60$ in 1997 from $\$ 2.67$ in 1996, while the average price of ICS and thermosiphon collectors increased to $\$ 23.28$ in 1997 from $\$ 21.63$ in 1996 . This increase was due primarily to increased material costs. The average price (in dollars per square foot) for flat-plate collectors in 1997 increased to $\$ 11.30$ from the 1996 level of $\$ 8.57$ (Figure 9). The value of shipments includes charges for advertising and warranties. Excluded are excise taxes and the cost of freight or transportation for the shipments.

\section{Markets}

In 1997, the residential sector was the largest market for solar thermal collectors. Solar thermal collectors shipped to the residential sector totaled 7.4 million square feet, 91 percent of total shipments (Table 19). This market sector primarily involves the use of low-temperature solar collectors for heating swimming pools and mediumtemperature collectors for water heating in residential buildings. The second-largest market for solar thermal collectors in 1997 was the commercial sector, which accounted for 9 percent of total shipments.

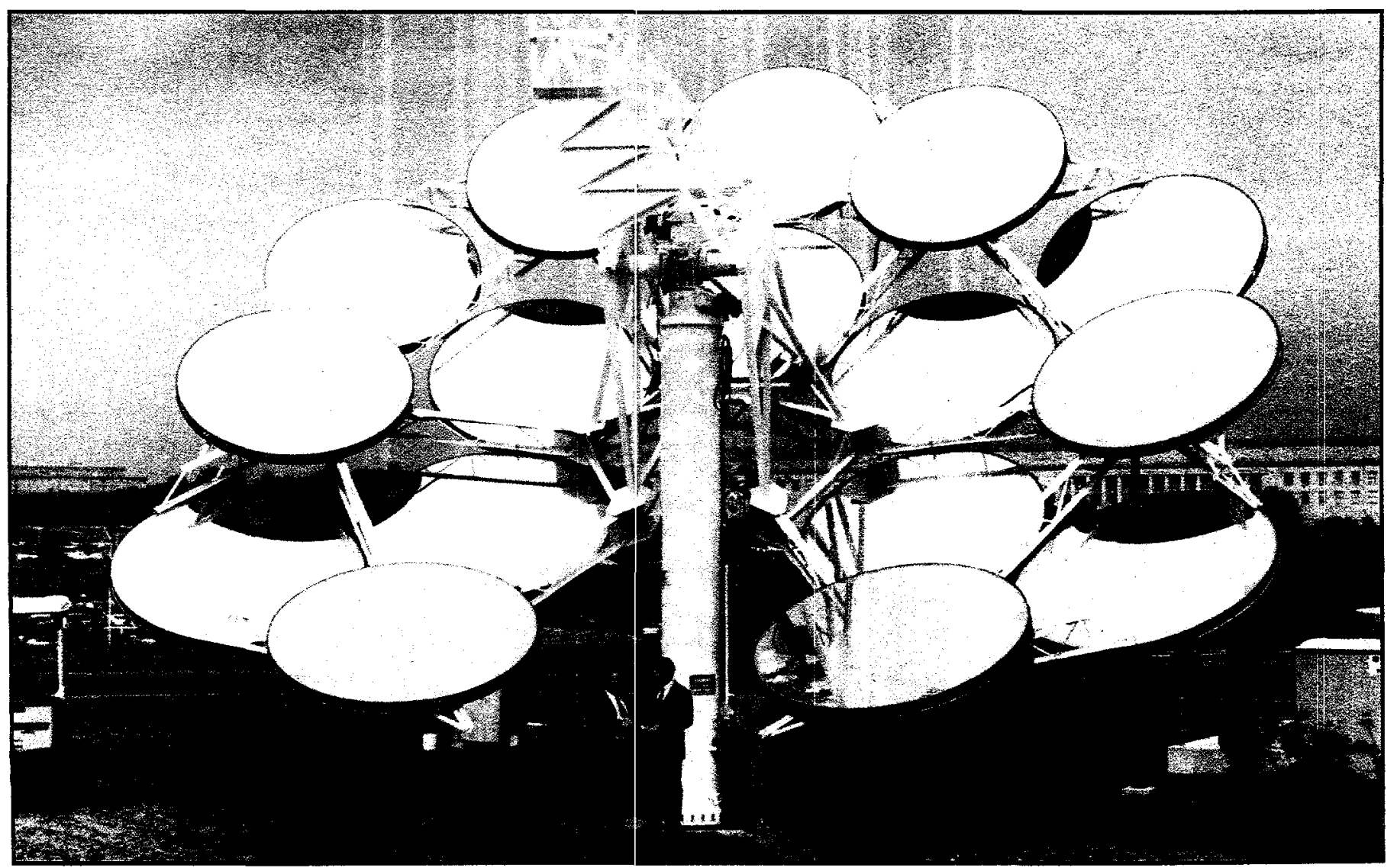

Sterling Engine Solar Dish Panels Demonstration Project Installed at the Pentagon. 


\begin{tabular}{|c|c|c|c|c|c|c|}
\hline \multirow[b]{2}{*}{ Type } & \multicolumn{3}{|c|}{1996} & \multicolumn{3}{|c|}{1997} \\
\hline & $\begin{array}{c}\text { Quantity } \\
\text { (thousand } \\
\text { square feet) }\end{array}$ & $\begin{array}{l}\text { Value } \\
\text { (thousand } \\
\text { dollars) }\end{array}$ & $\begin{array}{l}\text { Average Price } \\
\text { (dollars per } \\
\text { square foot) }\end{array}$ & $\begin{array}{c}\text { Quantity } \\
\text { (thousand } \\
\text { square feet) }\end{array}$ & $\begin{array}{c}\text { Value } \\
\text { (thousand } \\
\text { dollars) }\end{array}$ & $\begin{array}{c}\text { Average Price } \\
\text { (dollars per } \\
\text { square foot) }\end{array}$ \\
\hline \multicolumn{7}{|l|}{ Low-Temperature } \\
\hline Liquid and Air . . . . . . . . . & 6,821 & 18,227 & 2.67 & 7,524 & 19,584 & 2.60 \\
\hline \multicolumn{7}{|l|}{ Medium-Temperature } \\
\hline$\underset{\text { Liquid }}{\text { Air } \ldots \ldots \ldots \ldots \ldots \ldots \ldots}$ & \multicolumn{5}{|c|}{ Liquid } & 45.75 \\
\hline ICS/Thermosiphon $\ldots \ldots \ldots$ & 343 & 7,424 & 21.63 & 33 & 773 & 23.28 \\
\hline Flat Plate $\ldots \ldots \ldots \ldots \ldots$ & 431 & 3,697 & 8.57 & 516 & 5,835 & 11.30 \\
\hline Evacuated Tube $\ldots \ldots \ldots$ & 1 & 110 & 75.10 & 2 & 99 & 49.27 \\
\hline Concentrator $\ldots \ldots \ldots \ldots$ & 0 & 0 & -- & 0 & 0 & -- \\
\hline All Medium-Temperature ..... & 785 & 11,369 & 14.48 & 606 & 9,191 & 15.17 \\
\hline \multicolumn{7}{|l|}{ High-Temperature } \\
\hline Parabolic Dish and Trough .... & 10 & 180 & 18.75 & 7 & 180 & 25.00 \\
\hline Total $\ldots \ldots \ldots \ldots \ldots \ldots \ldots$ & 7,616 & 29,776 & 3.91 & 8,138 & $28,970^{a}$ & 3.56 \\
\hline
\end{tabular}

${ }^{a}$ Total includes institutional research projects.

ICS = Integral collector storage.

Notes: Totals may not equal sum of components due to independent rounding.

Source: Energy Information Administration, Form EIA-63A, "Annual Solar Thermal Collector Manufacturers Survey."

Figure 9. Average Price of Solar Thermal Collector Shipments by Collector Type, 1995, 1996, and 1997

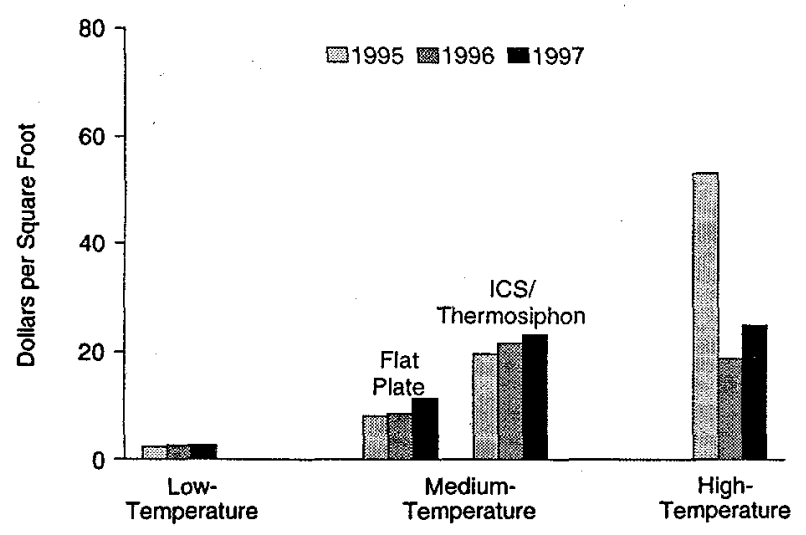

Source: Energy Information Administration, Form EIA-63A, "Annual Solar Thermal Collector Manufacturers Survey."

\section{Uses}

In 1997, the largest end use for solar thermal collectors shipped was for heating swimming pools, representing 93 percent of the total square feet shipped. Swimming pools generally use low-temperature collectors. A common low-temperature pool-heating solar collector is a black plastic or rubber-like sheet with tubing through which water is circulated. The heat of the sun is transferred directly from the black absorbing material to the water circulating through the tubing to supply heat to the pool. Shipments for pool heating increased 11 percent in 1997 from the level reported in 1996.

The second largest end use in 1997 was for domestic hot water systems, which accounted for 7 percent of the total square feet shipped. Typical solar water-heating systems feature flat-plate collectors or collectors installed in an ICS or thermosiphon system. Unlike poolheating systems, domestic solar water-heating systems nearly always have a conventional backup (e.g., gas or electric). Shipments in 1997 for hot water systems decreased 22 percent from the 1996 level.

Medium-temperature collectors also were shipped for space heating and for installation into systems that provide both space and water heating, and process heating. Almost all high-temperature parabolic dish and trough collectors were shipped for hot water heating in 1997.

\section{System Shipments}

Twenty-nine companies reported 13,951 shipments of complete solar thermal collector systems in 1997, a 55percent increase compared with 1996 (Table 20). 
Table 19. Shipments of Solar Collectors by Market Sector, End Use, and Type, 1996 and 1997 (Thousand Square Feet)

\begin{tabular}{|c|c|c|c|c|c|c|c|c|c|}
\hline \multirow[b]{3}{*}{ Type } & \multirow{3}{*}{\begin{tabular}{|c|}
$\begin{array}{c}\text { Low- } \\
\text { Temperature }\end{array}$ \\
Liquid/Air \\
Metallic and \\
Nonmetallic \\
\end{tabular}} & \multicolumn{5}{|c|}{ Medium-Temperature } & \multirow{3}{*}{$\begin{array}{c}\begin{array}{c}\text { High- } \\
\text { Temperature }\end{array} \\
\\
\text { Parabolic } \\
\text { Dish/Trough } \\
\end{array}$} & \multirow[b]{3}{*}{$\begin{array}{l}1997 \\
\text { Total } \\
\end{array}$} & \multirow[b]{3}{*}{$\begin{array}{l}1996 \\
\text { Total } \\
\end{array}$} \\
\hline & & \multirow[b]{2}{*}{ Air } & \multicolumn{4}{|c|}{ Liquid } & & & \\
\hline & & & $\begin{array}{l}\text { ICS/Ther. } \\
\text { mosiphori }\end{array}$ & $\begin{array}{l}\text { Flat-Plate } \\
\text { (Pumped) }\end{array}$ & $\begin{array}{c}\text { Evacuated } \\
\text { Tube }\end{array}$ & $\begin{array}{c}\text { Concen- } \\
\text { trator }\end{array}$ & & & \\
\hline \multicolumn{10}{|l|}{ Market Sector } \\
\hline Residential . . & 6,791 & 53 & 24 & 491 & 1 & 0 & 0 & 7,360 & 6,873 \\
\hline Commercial ........ & 726 & 1 & 9 & 25 & 0 & 0 & 7 & 768 & 682 \\
\hline Industrial ..... & 7 & 0 & 0 & 0 & 0 & 0 & 0 & 7 & 54 \\
\hline Utility $\ldots \ldots \ldots \ldots \ldots$ & 0 & 0 & * & 0 & * & 0 & 0 & 1 & * \\
\hline Other $^{\mathrm{a}} \ldots \ldots \ldots \ldots \ldots$ & 0 & 1 & 0 & 0 & 1 & 0 & 0 & 2 & 7 \\
\hline Total ............ & 7,524 & 54 & 33 & 516 & 2 & 0 & 7 & 8,138 & 7,616 \\
\hline \multicolumn{10}{|l|}{ End Use } \\
\hline Pool Heating ... & 7,517 & 0 & 7 & 4 & 0 & 0 & 0 & 7,528 & 6,787 \\
\hline Hot Water . . . . . . . . & 0 & 52 & 26 & 509 & 1 & 0 & 7 & 595 & 765 \\
\hline Space Heating . . . . . . & 7 & 2 & 0 & 0 & 0 & 0 & 0 & 10 & 57 \\
\hline Space Cooling . . . . . . & 0 & 0 & 0 & 0 & 0 & 0 & 0 & 0 & 0 \\
\hline \multicolumn{10}{|l|}{ Combined Space and } \\
\hline Water Heating ..... & 0 & 0 & 0 & 3 & 0 & 0 & * & 4 & 3 \\
\hline $\begin{array}{l}\text { Process Heating } \ldots . \\
\text { Electricity }\end{array}$ & 0 & 0 & 0 & 0 & 0 & 0 & 0 & 0 & 4 \\
\hline Generation $\ldots \ldots$ & 0 & 0 & 0 & 0 & 0 & 0 & 0 & $\mathbf{0}$ & * \\
\hline Other ${ }^{b} \ldots \ldots \ldots$ & * & 0 & 0 & - & 1 & 0 & 0 & 2 & 0 \\
\hline Total $\ldots \ldots \ldots \ldots$. . & 7,524 & 54 & 33 & 516 & 2 & $\mathbf{0}$ & 7 & 8,138 & 7,616 \\
\hline
\end{tabular}

*Less than 500 square feet.

${ }^{2}$ Other market sectors include shipments of solar thermal collectors to other sectors such as government, including the military but excluding space applications.

${ }^{b}$ Other end use includes shipments of solar thermal collectors for other uses such as cooking, water pumping, water purification, desalinization, distilling, etc.

ICS = Integral Collector Storage.

Note: Totals may not equal sum of components due to independent rounding.

Source: Energy Information Administration, Form EIA-6\$A, "Annual Solar Thermal Collector Manufacturers Survey."

Table 20. Shipments of Complete Solar Thermal Collector Systems, 1996 and 1997

\begin{tabular}{|c|c|c|}
\hline Shipment Information & 1996 & 1997 \\
\hline \multicolumn{3}{|l|}{ Complete Collector Systems } \\
\hline Shipped . . . . . . . . . & 9,013 & $13,95 !$ \\
\hline Thousand Square Feet & 2,093 & 2,975 \\
\hline Percent of Total Shipments & 27 & 37 \\
\hline Number of Companies . . . . . & 28 & 29 \\
\hline Value of Systems (thousand dollars) & 10,754 & 14,317 \\
\hline
\end{tabular}

Source: Energy information Administration, Form EIA-63A, "Annual Solar Thermal Collector Manufacturers Survey."

A complete system is a unit with a collector and all the necessary functional components, except for installation materials. It includes thermosiphon systems, integral collector storage systems, packaged systems, and system kits. The 13,951 complete systems accounted for 3.0 million square feet of collectors, an increase of 42 percent in square feet shipped above the 1996 level. The total value for the systems shipped in 1997 was $\$ 14.3$ million, compared with $\$ 10.8$ million in 1996.

\section{Industry Status}

In 1997, 29 companies were active in the solar thermal collector manufacturing industry. This is virtually unchanged from 1996 and interrupts a decade-long decline. However, it is a sizable decrease from prior years (Table 12). Since 1987, 30 manufacturing companies have left the market. Firms leaving the market have been principally those engaged partially in nonsolar-related businesses. This decade long decrease is due in large measure to two factors. First, the 40-percent residential energy tax credit and the 15-percent business energy tax 
credit expired at the end of 1985 . Second, the decline in industry companies intensified with the drop in oil prices in 1986. The reinstatement of the business energy tax credit-at the 15-percent level for 1986, at the 12percent level for 1987 through 1991, and at the 10-percent level in 1992-plus increasing oil prices after 1986, appear to have had little effect on drawing companies into manufacturing solar thermal collectors. ${ }^{14}$

Despite the decrease in firms producing solar collectors, those firms still in business shipped 0.5 million more square feet in 1997 than in 1996 (Table 12). Of the 29 active companies, 3 are planning to introduce new lowtemperature collectors, 9 are planning new mediumtemperature collectors, and 2 expect to introduce new high-temperature collectors in 1998 (Table 21).

Table 21. Number of Companies Expecting To Introduce New Solar Thermal Collector Products In 1998

\begin{tabular}{c|c}
\hline New Product Type & $\begin{array}{c}\text { Number of } \\
\text { Companies }\end{array}$ \\
\hline Low-Temperature Collectors ....... & 3 \\
Medium-Temperature Collectors .... & 9 \\
High-Temperature Collectors ....... & 2 \\
Noncollector Components ....... & 3 \\
\hline
\end{tabular}

Source: Energy Information Administration, Form EIA-63A, "Annual Solar Thermal Collector Manufacturers Survey."

At the end of 1996, 30 States were providing financial incentives for investment in the use of solar thermal collectors and photovoltaic cells and modules. The legislative actions were passed to encourage the use of an environmentally clean source of energy, to promote energy conservation through the use of renewable energy technologies, and to promote energy efficiency. Among the most common incentives were property tax exemptions and income tax credits for both the residential and business sectors.

Since 1987, the 10 largest U.S. companies that shipped solar thermal collectors have supplied not less than 95 percent of all solar thermal collectors manufactured in or imported into the United States (Table 22). In 1997, 97 percent of the approximately 7.9 million square feet of total shipments were supplied by the 10 largest companies.
Table 22. Percent of Solar Collector Shipments by the 10 Largest Companies, 1987-1997

\begin{tabular}{|c|c|c|c|}
\hline Year & $\begin{array}{c}\text { Company } \\
\text { Rank }\end{array}$ & $\begin{array}{l}\text { Shipments } \\
\text { (thousand } \\
\text { square feet) }\end{array}$ & $\begin{array}{c}\text { Percent of } \\
\text { Total } \\
\text { Shipments }\end{array}$ \\
\hline $1987 \ldots \ldots$ & $\begin{array}{c}1-5 \\
6-10\end{array}$ & $\begin{array}{r}6,371 \\
499\end{array}$ & $\begin{array}{r}88 \\
7\end{array}$ \\
\hline $1988 \ldots \ldots$ & $\begin{array}{c}1-5 \\
6-10\end{array}$ & $\begin{array}{r}7,585 \\
335\end{array}$ & $\begin{array}{r}93 \\
4\end{array}$ \\
\hline 1989 & $\begin{array}{c}1-5 \\
6-10\end{array}$ & $\begin{array}{l}9,748 \\
1,321\end{array}$ & $\begin{array}{l}85 \\
12\end{array}$ \\
\hline$\ldots \ldots$ & $\begin{array}{c}1-5 \\
6-10\end{array}$ & $\begin{array}{l}9,955 \\
1,029\end{array}$ & $\begin{array}{r}87 \\
9\end{array}$ \\
\hline$\ldots \ldots$ & $\begin{array}{c}1-5 \\
6-10\end{array}$ & $\begin{array}{r}5,429 \\
829\end{array}$ & $\begin{array}{l}83 \\
13\end{array}$ \\
\hline $1992 \ldots \ldots$ & $\begin{array}{c}1-5 \\
6-10\end{array}$ & $\begin{array}{r}6,110 \\
609\end{array}$ & $\begin{array}{r}86 \\
9\end{array}$ \\
\hline$\ldots \ldots$ & $\begin{array}{c}1-5 \\
6-10\end{array}$ & $\begin{array}{r}6,135 \\
551\end{array}$ & $\begin{array}{r}88 \\
8\end{array}$ \\
\hline$\ldots \ldots$ & $\begin{array}{c}1-5 \\
6-10\end{array}$ & $\begin{array}{r}6,401 \\
861\end{array}$ & $\begin{array}{l}84 \\
12\end{array}$ \\
\hline 1995 & $\begin{array}{c}1-5 \\
6-10\end{array}$ & $\begin{array}{r}6,525 \\
806\end{array}$ & $\begin{array}{l}85 \\
11\end{array}$ \\
\hline$\ldots \ldots$ & $\begin{array}{c}1-5 \\
6-10\end{array}$ & $\begin{array}{r}6,452 \\
910\end{array}$ & $\begin{array}{l}85 \\
12\end{array}$ \\
\hline 1997 & $\begin{array}{c}1-5 \\
6-10\end{array}$ & $\begin{array}{r}7,183 \\
731\end{array}$ & $\begin{array}{r}88 \\
9\end{array}$ \\
\hline
\end{tabular}

Note: Totals may not equal sum of components due to independent rounding.

Source: Energy Information Administration: Form EIA-63A, "Annual Solar Thermal Collector Manufacturers Survey."

Employment in solar-thermal-related activities decreased 56 person-years in 1997 to 184 person-years, a 23-percent drop from the 1996 employment level of 239. Industry employment data for 1994 through 1997 are as follows:

14 In an effort to stimulate domestic energy sources, the Energy Policy Act of 1992, Section 1916, extended the 10-percent business tax credits for solar equipment indefinitely, retroactive to June 30,1992. Investors in or purchasers of qualified solar energy property can take the credit on up to 10 percent of the investment or purchase price and installment amount. Section 1914 established a 1.5 -cent per kilowatthour electricity production incentive for "qualifying facilities." 
Most of the 29 reporting companies in 1997 combined manufacturing and related activities with importing of solar thermal collectors including:

- A total of 22 companies were involved in the design of collectors or systems, 12 were developing prototype collectors, and 7 were developing prototype systems (Table 23 ).

- There were 20 companies with wholesale distribution activities and 14 companies with retail distribution activities. Of the 29 companies, 11 offered installation of their collectors.

Table 23. Companies Involved in Solar Thermal Activities by Type, 1996 and 1997

\begin{tabular}{|c|c|c|}
\hline Type of Activity & 1996 & 1997 \\
\hline Collector or System Design . . . . . . & 20 & 22 \\
\hline Prototype Collector Development . . & 15 & 12 \\
\hline Prototype System Development . . . & 7 & 7 \\
\hline Wholesale Distribution ... & 19 & 20 \\
\hline Retail Distribution . . . . & 12 & 14 \\
\hline Installation $\ldots \ldots \ldots \ldots \ldots \ldots$ & 9 & 11 \\
\hline \multicolumn{3}{|l|}{ Noncollector System Component } \\
\hline Manufacture $\ldots \ldots \ldots \ldots \ldots$ & 7 & 9 \\
\hline
\end{tabular}

Source: Energy Information Administration, Form EIA-63A, "Annual Solar Thermal Collector Manufacturers Survey."

Solar-related sales represented 90 to 100 percent of total company sales for 19 companies in 1997 versus 21 companies in 1996 (Table 24). Solar-related sales made up less than 10 percent of total sales for 4 companies in 1997, compared with 3 companies in 1996.

\section{Photovoltaic Module and Cell Manufacturing Activities}

\section{Photovoltaic Module and Cell Description}

Photovoltaic (PV) components are divided into three categories by product type: (1) crystalline silicon cells and modules which include single-crystal, cast silicon, and ribbon silicon; (2) thin-film cells and modules made from a number of layers of photosensitive materials such as amorphous silicon; and (3) concentrator cells and modules in which a lens is used to gather and converge sunlight onto the cell or module surface.
Table 24. Solar-Related Sales as a Percentage of Total Sales, 1996 and 1997

\begin{tabular}{c|c|c}
\hline \multirow{2}{*}{$\begin{array}{c}\text { Solar-Related Sales as a } \\
\text { Percent of Total Sales }\end{array}$} & \multicolumn{2}{|c}{ Number of Companies } \\
\cline { 2 - 3 } & 1996 & 1997 \\
\hline $90-100 \ldots \ldots \ldots \ldots \ldots \ldots \ldots \ldots \ldots$ & 21 & 19 \\
$50-89 \ldots \ldots \ldots \ldots \ldots \ldots \ldots$ & 4 & 5 \\
$10-49 \ldots \ldots \ldots \ldots$ & 0 & $\ldots \ldots \ldots \ldots$ \\
Less than $10 \ldots \ldots \ldots \ldots \ldots \ldots$ & 3 & 1 \\
Total $\ldots \ldots \ldots$ & $\ldots \ldots \ldots \ldots \ldots$ & 4 \\
\hline
\end{tabular}

Source: Energy Information Administration, Form EIA-63A, "Annual Solar Thermal Collector Manufacturers Survey."

\section{Shipments}

PV. module and cell shipments in 1997 surged to 46.4 peak megawatts (Table 25). Module shipments accounted for 33.6 peak megawatts, while cell shipments accounted for 12.7 peak megawatts. Module shipments increased 37 percent in 1997 from 1996, while cell shipments increased 16 percent. Total PV shipments in 1997 were 31 percent above the 1996 level. Total shipments have increased 632 percent since 1986 (Table 26 and Figure 10). Data for PV cells and modules are for terrestrial use only (i.e., excluding space applications) and have been reported each year since 1982 .

Table 25. Annual Shipments of Photovoltaic Cells and Modules, 1995-1997 (Peak Kilowatts)

\begin{tabular}{c|c|c|c}
\hline Item & 1995 & 1996 & 1997 \\
\hline Cells $\ldots \ldots \ldots \ldots \ldots$ & 11,432 & 10,930 & 12,709 \\
Modules . . . . . . . & 19,627 & 24,534 & 33,645 \\
Total . . . . . . . & 31,059 & 35,464 & 46,354 \\
\hline
\end{tabular}

Source: Energy Information Administration, Form ElA-63B, "Annual Photovoltaic Module/Cell Manufacturers Survey."

\section{Imports}

Four companies imported PV cells and modules in 1997 totaling 1.9 peak megawatts, or 4 percent of total shipments (Table 26). The predominant type of imported PV cells and modules was crystalline silicon. These imports originated in Australia, England, India, and Japan, with Japan accounting for most of the imported PV cells and modules. 
Table 26. Annual Shipments of Photovoltaic Cells and Modules, 1986-1997

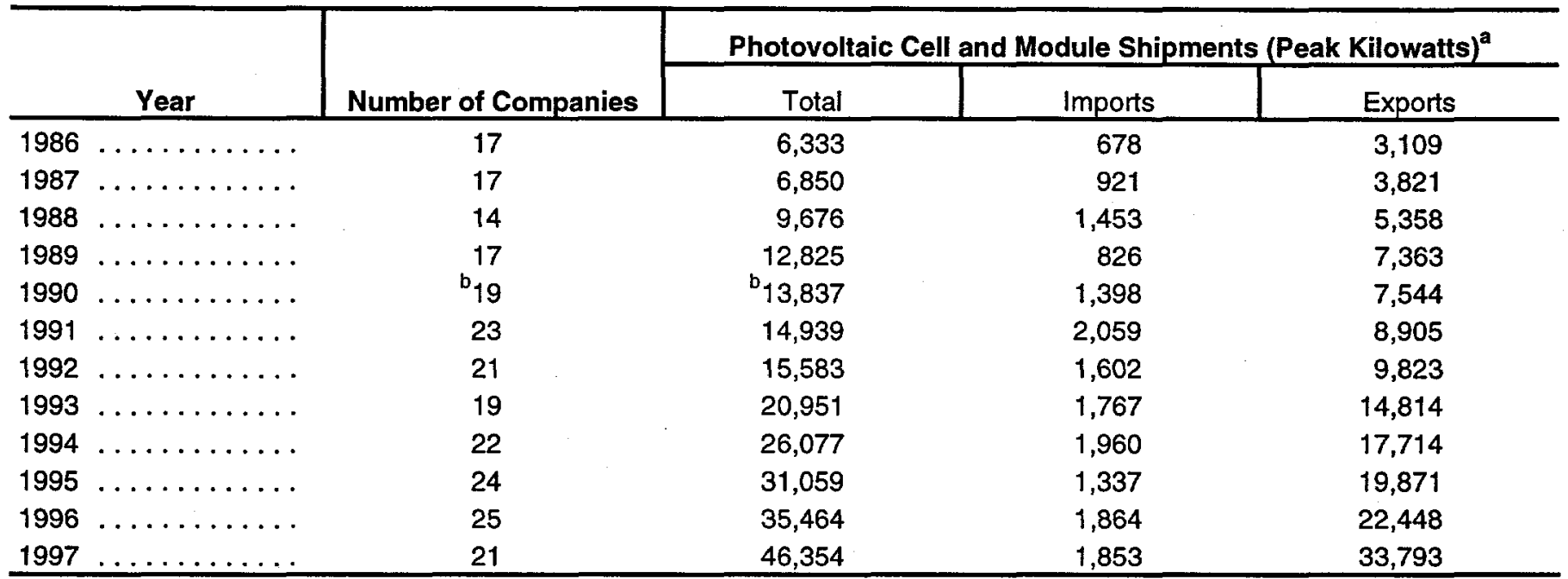

${ }^{a}$ Does not include shipments of cells and modules for space/satellite applications.

b Includes imputed data for one nonrespondent which exited the industry during 1990.

Note: Total shipments as reported by respondents include all domestic and export shipments and may include imported collectors that subsequently were shipped to domestic or foreign customers.

Source: Energy Information Administration, Form EIA-63B, "Annual Photovoltaic Module/Cell Manufacturers Survey."

\section{Figure 10. Import and Export Shipments of Photovoltaic Cells and Modules, 1988-1997}

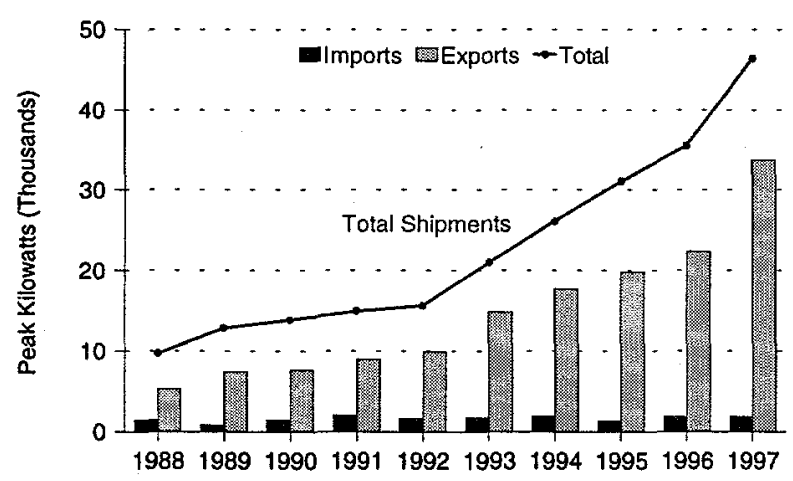

Note: Total shipments as reported by respondents include all domestic and export shipments and may include imports that subsequently were shipped to domestic or foreign customers.

Source: Energy Information Administration, Form ElA-63B, "Annual Photovoltaic Module/Cell Manufacturers Survey."

\section{Distribution}

In 1997, PV module and cell shipments totaling 31.4 peak megawatts (68 percent of total shipments) were sent directly to wholesale distributors (Table 27). Installers and end users combined received 2.8 peak megawatts $(6$ percent of total shipments).
PV cell manufacturers shipped 5.2 peak megawatts (11 percent of total shipments) to other companies that manufacture (assemble) cells into PV modules.

\section{Cell and Module Types}

Crystalline silicon cells and modules continued to dominate the PV industry in 1997, accounting for 96 percent of total shipments (Table 28). In particular, singlecrystal silicon shipments totaled 30 peak megawatts, an increase of 38 percent compared with corresponding 1996 shipments (Figure 11). Together, cast and ribbon silicon shipments totaled 14.3 peak megawatts in 1997 , a 17-percent increase over 1996. From 1996 to 1997, thinfilm shipments increased 31 percent (Table 28). However, thin-film shipments represented only 4.1 percent of total shipments in 1997.

\section{Values and Prices}

The total value of photovoltaic module and cell shipments was $\$ 175$ million in 1997, a 34-percent increase over the 1996 value of $\$ 131$ million (Table 29). The total value includes charges for advertising and warranties, but does not include excise taxes and the cost of freight or transportation for the shipments.

The total value of crystalline silicone (single-crystal, cast, and ribbon) shipments was $\$ 164$ million in 1997, a 35percent increase compared with the corresponding 1996 


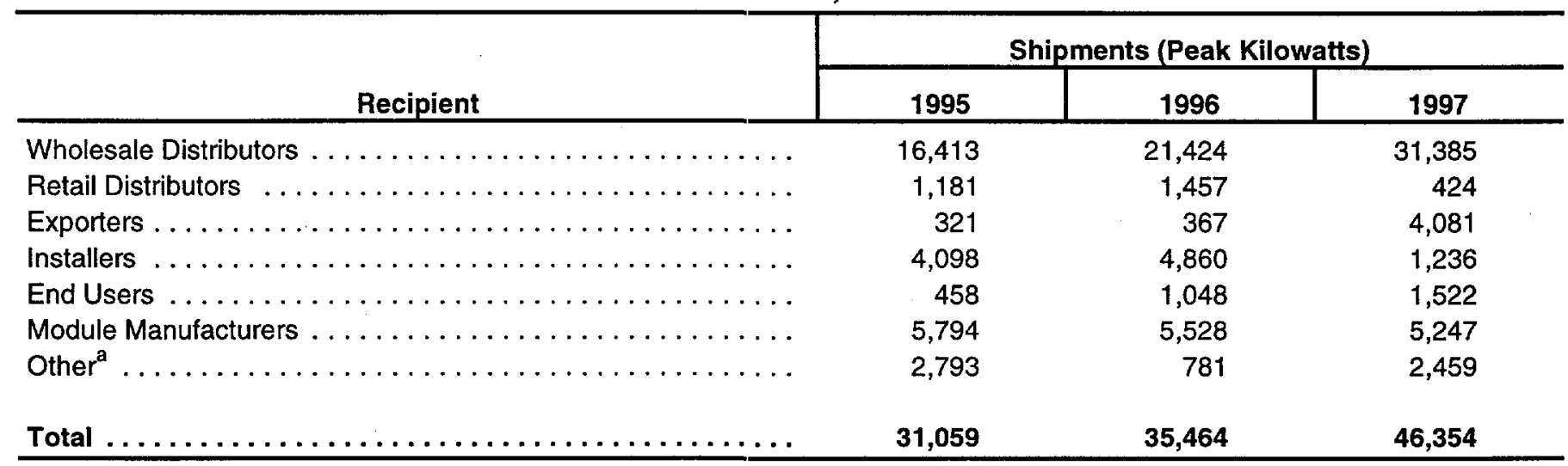

${ }^{a}$ Other includes categories not identified by reporting compranies.

Note: Totals may not equal sum of components due to independent rounding.

Source: Energy Information Administration, Form EIA-63B, "Annual Photovoltaic Module/Cell Manufacturers Survey."

Table 28. Photovoltaic Cell and Module Shipments by Type, 1995-1997

\begin{tabular}{|c|c|c|c|c|c|c|}
\hline \multirow[b]{2}{*}{ Type } & \multicolumn{3}{|c|}{ Shipments (Peak Kilowatts) } & \multicolumn{3}{|c|}{ Percent of Total } \\
\hline & 1995 & 1996 & 1997 & 1995 & 1996 & 1997 \\
\hline \multicolumn{7}{|l|}{ Crystalline Silicon } \\
\hline Single-Crystal & 19,857 & 21,742 & 29,997 & 64 & 61 & 65 \\
\hline Cast and Ribbon & 9,883 & 12,255 & 14,317 & 32 & 35 & 31 \\
\hline Subtotal ...... & 29,740 & 33,996 & 44,677 & 96 & 96 & 96 \\
\hline Thin-Film Silicon & 1,266 & 1,445 & 1,886 & 4 & 4 & 4 \\
\hline Concentrator Silicon $\ldots \ldots \ldots \ldots$ & 53 & 23 & 154 & * & * & * \\
\hline Other ${ }^{a}$ & 0 & 0 & 0 & 0 & 0 & 0 \\
\hline Total $\ldots \ldots \ldots \ldots \ldots \ldots \ldots$ & 31,059 & 35,464 & 46,354 & 100 & 100 & 100 \\
\hline
\end{tabular}

${ }^{a}$ Includes categories not identified by reporting companies.

* = Less than 0.5 percent.

Notes: Data do not include shipments of cells and modules for space/satellite applications. Totals may not equal sum of components due to independent rounding.

Source: Energy Information Administration, Form EIA-63B, "Annual Photovoltaic Module/Cell Manufacturers Survey.”

value. The average price of crystalline silicon modules in 1997 was $\$ 4.06$ per peak watt, an increase of 3 percent from the 1996 price of $\$ 3.95$ (Table 29).

\section{Uses}

The largest end-use application of PV cells and module; in 1997 was for electricity generation (combined gridinteractive and remote). This represented 36 percent of total shipments (Table 30 ). Of the 16.9 peak megawatts represented by this end use, 94 percent involved crystalline silicon cells and modules. Grid interactive and remote (i.e., stand-alone) power generation include applications for grid distribution and general remote uses, such as residential power and power for mobile homes. The second-largest PV end use in 1997 was in the communication sector, which accounted for 7.4 peak megawatts. An example of use in the commercial sector is the utilization of PV units to power fixed-based communications equipment, such as mountain-top signal-repeater stations. This sector represented 16 percent of total shipments. In 1997, transportation was the third-largest PV end-use application, representing 14 percent of total shipments.

In 1997, end uses related to water pumping and original equipment manufacturers accounted for 3.8 peak megawatts and 5.2 peak megawatts, respectively, and 
Figure 11. Photovoltaic Cell and Module Shipments by Type, 1994-1997

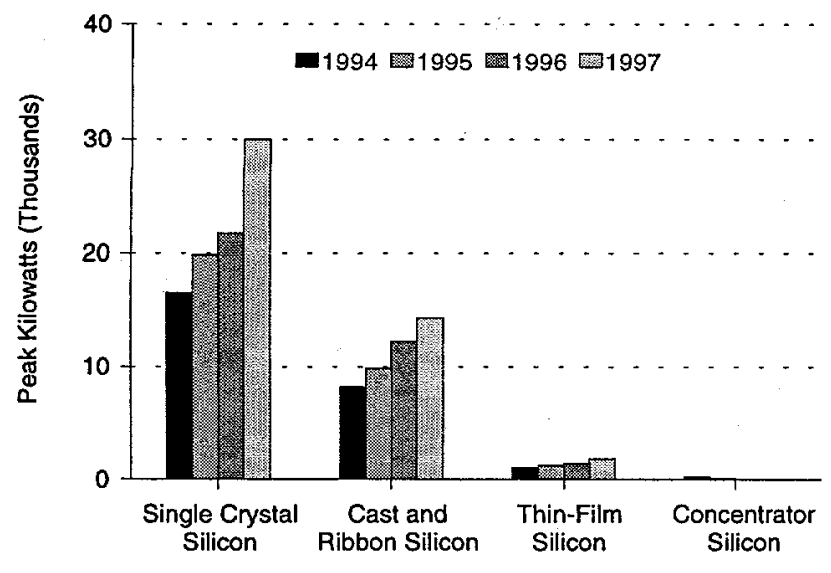

Source: Energy Information Administration, Form EIA-63B, "Annual Photovoltaic Module/Cell Manufacturers Survey."

involved primarily the use of crystalline silicon cells and modules.

Sales for consumer goods accounted for 0.3 peak megawatts in 1997. PV cells and modules used for health and medical purposes, such as to power refrigerators, medical equipment, and water purifiers, totaled 1.3 peak megawatts in 1997, a 33-percent increase over the 1996 level. End uses reported as "Other" for 1997 totaled 4.7 peak megawatts.

\section{Destinations}

\section{Market Sectors}

The industrial sector was the largest market for PV cells and modules in 1997, accounting for 25 percent of total shipments (Table 30). This sector contains much of the nonutility electric generation capacity. The secondlargest market sector was the residential sector, which purchased 24 percent of shipments. The commercial sector represented the third-largest market for PV shipments in 1997 with 18 percent. These cells and modules were shipped to provide power for establishments such as office buildings, retail establishments, private hospitals, and schools (publicly owned hospitals and schools are listed under the government sector).

PV cells and modules for the transportation sector, which were used to produce power on boats, in cars, in recreational vehicles, and to power transportation support systems, amounted to 3.6 megawatts. The transportation sector accounted for 8 percent of total shipments in 1997 compared with 11 percent in 1996.

Shipments to the utility sector, where cells and modules were used to produce power at utility-owned systems including central stations, decentralized systems, and experimental applications, amounted to 5.7 peak megawatts in 1997, a 19-percent increase from 1996. Combined with information from the analysis of PV's by end use, it is clear that there is considerable use of PV cells

Table 29. Photovoltaic Cell and Module Shipment Values by Type, 1996 and 1997

\begin{tabular}{|c|c|c|c|c|c|c|}
\hline \multirow[b]{3}{*}{ Type } & \multicolumn{3}{|c|}{1996} & \multicolumn{3}{|c|}{1997} \\
\hline & \multirow{2}{*}{$\begin{array}{l}\text { Value } \\
\text { (Thousand } \\
\text { Dollars) }\end{array}$} & \multicolumn{2}{|c|}{$\begin{array}{c}\text { Average Price } \\
\text { (Dollars per Peak Watt) }\end{array}$} & \multirow{2}{*}{$\begin{array}{l}\text { Value } \\
\text { (Thousand } \\
\text { Dollars) }\end{array}$} & \multicolumn{2}{|c|}{$\begin{array}{c}\text { Average Price } \\
\text { (Dollars per Peak Watt) }\end{array}$} \\
\hline & & Modules & Cells & & Modules & Cells \\
\hline \multicolumn{7}{|l|}{ Crystalline Silicon } \\
\hline Single-Crystal . & 75,043 & 3.97 & 2.81 & 108,226 & 4.08 & 2.81 \\
\hline Cast and Ribbon & 46,646 & 3.92 & 2.73 & 55,701 & 4.03 & 2.59 \\
\hline Subtotal . . . . . . . & 121,689 & 3.95 & 2.80 & 163,927 & 4.06 & 2.78 \\
\hline Thin-Film Silicon .... & W & W & $W$ & W & W & $W$ \\
\hline Concentrator Silicon $\ldots \ldots \ldots \ldots$. & W & W & W & w & w & W \\
\hline Other $^{a} \ldots \ldots \ldots \ldots \ldots \ldots$ & 0 & $\cdots$ & -- & 0 & -- & -- \\
\hline Total $\ldots \ldots \ldots \ldots \ldots \ldots \ldots$ & 131,066 & 4.09 & 2.80 & 175,089 & 4.16 & 2.78 \\
\hline
\end{tabular}

${ }^{a}$ Includes categories not identified by reporting companies.

$W=$ Data withheld to avoid disclosure of proprietary company data.

-- = Does not apply.

Notes: Data do not include shipments of cells and modules for space/satellite applications. Totals may not equal sum of components due to independent rounding.

Source: Energy Information Administration, Form EIA-63B, "Annual Photovoltaic Module/Cell Manufacturers Survey." 
Table 30. Shipments of Photovoltaic Cells and Modules by Market Sector, End Use, and Type, 1996 and 1997 (Peak Kilowatts)

\begin{tabular}{|c|c|c|c|c|c|c|}
\hline Sector and End Use & $\begin{array}{c}\text { Crystalline } \\
\text { Silicon }^{\mathrm{a}}\end{array}$ & $\begin{array}{c}\text { Thin-Film } \\
\text { Silicon }\end{array}$ & $\begin{array}{c}\text { Concentrator } \\
\text { Silicon }\end{array}$ & Other & 1997 Total & 1996 Total \\
\hline \multicolumn{7}{|l|}{ Market Sector } \\
\hline$\ldots \ldots \ldots \ldots \ldots$ & 11,244 & 504 & 0 & 0 & 11,748 & 8,300 \\
\hline Residential $\ldots \ldots \ldots \ldots \ldots$ & 10,691 & 300 & 2 & 0 & 10,993 & 8,475 \\
\hline Commercial. & 7,621 & 340 & 150 & 0 & 8,111 & 5,176 \\
\hline$\ldots \ldots \ldots \ldots$ & 3,378 & 196 & 0 & 0 & 3,574 & 3,995 \\
\hline Utility $\ldots \ldots \ldots \ldots \ldots \ldots$ & 5,331 & 320 & 0 & 0 & 5,651 & 4,753 \\
\hline Government $^{b} \ldots \ldots \ldots \ldots$ & 3,772 & 135 & 2 & 0 & 3,909 & 3,126 \\
\hline Other $^{c} \ldots \ldots \ldots \ldots \ldots \ldots$ & 2,276 & 91 & 0 & 0 & 2,367 & 1,639 \\
\hline Total $\ldots \ldots \ldots \ldots \ldots \ldots \ldots$ & 44,314 & 1,886 & 154 & 0 & 46,354 & 35,464 \\
\hline \multicolumn{7}{|l|}{ End Use } \\
\hline \multicolumn{7}{|l|}{ Electricity Generation } \\
\hline Grid Interactive $\ldots \ldots \ldots \ldots$ & 7,402 & 871 & 0 & 0 & 8,273 & 4,844 \\
\hline Remote $\ldots \ldots \ldots \ldots \ldots \ldots$ & 8,433 & 195 & 2 & 0 & 8,630 & 10,884 \\
\hline Communications .... & 7,289 & 94 & 0 & 0 & 7,383 & 6,041 \\
\hline Consumer Goods & 72 & 275 & 0 & 0 & 347 & 1,063 \\
\hline Transportation ... & 6,645 & 60 & 0 & 0 & 6,705 & 5,196 \\
\hline Water Pumping ..... & 3,748 & 35 & 0 & 0 & 3,783 & 3,261 \\
\hline Cells/Modules to OEM ${ }^{d}$.. & 4,984 & 261 & 0 & 0 & 5,245 & 2,410 \\
\hline Health $\ldots \ldots \ldots \ldots \ldots \ldots$ & 1,267 & 36 & 0 & 0 & 1,303 & 977 \\
\hline Other $^{\theta} \ldots \ldots \ldots \ldots \ldots \ldots$ & 4,473 & 59 & 152 & 0 & 4,684 & 789 \\
\hline Total $\ldots \ldots \ldots \ldots \ldots \ldots \ldots$ & 44,314 & 1,886 & 154 & $\mathbf{0}$ & 46,354 & 35,464 \\
\hline
\end{tabular}

${ }^{a}$ Includes single-crystal and cast and ribbon types.

Includes Federal, State, and local governments, excluding military.

${ }^{c}$ Other includes shipments that are manufactured for private contractors for research and development projects.

dOriginal equipment manufacturers.

'Other uses include shipments of photovoltaic cells and modules for other uses, such as cooking food, desalinization, distilling, etc.

Source: Energy Information Administration, Form EIA-63E, “Annual Photovoltaic Module/Cell Manufacturers Survey."

and modules for electricity generation-even grid interactive uses-outside the utility sector.

Shipments of PV cells and modules used to produce power at installations of Federal, State, or local governments (excluding military) totaled 3.9 peak megawatts in 1997. This compares with 3.1 peak megawatts shipped to the government sector in 1996. The "Other" sector in 1997 consisted of 2.4 peak megawatts shipped to foreign governments or used for speciality purposes.

\section{Exports}

Export shipments totaled 33.8 peak megawatts in 1997 (Table 31), an increase of 51 percent from 1996 levels. Generally, export shipments since 1990 have increased because of the continued search for new PV markets outside the United States (Figure 10). A total of 17 companies reported exports of PV cells and modules in 1997, with exports accounting for 73 percent of total PV shipments. Of all types of cells and modules exported in 1997, 98 percent were crystalline silicon (Table 31). Destinations of PV exports by continent, region, and by country are shown in Table 32. Two countries, Germany and Japan, received the greatest share of exports, totaling 57 percent in 1997.

\section{Systems}

Of the 21 companies that reported shipments of PV systems in 1997, 12 reported shipments of 3,926 complete photovoltaic systems, an increase of 143 percent from 1996 (Table 33). A complete photovoltaic system is defined as a power supply unit that satisfies all the power requirements of an application. Such a system is generally made up of one or more modules, a power 
Table 31. Export Shipments of Photovoltaic Cells and Modules by Type, 1996 and 1997 (Peak Kilowatts)

\begin{tabular}{|c|c|c|c|c|c|c|c|c|}
\hline \multirow[b]{3}{*}{ Item } & \multicolumn{8}{|c|}{ Type } \\
\hline & \multicolumn{2}{|c|}{ Crystalline Silicon } & \multicolumn{2}{|c|}{ Thin-Film Silicon } & \multicolumn{2}{|c|}{ Concentrator Silicon } & \multicolumn{2}{|c|}{ Total } \\
\hline & 1996 & 1997 & 1996 & 1997 & 1996 & 1997 & 1996 & 1997 \\
\hline Cells & 8,312 & 10,837 & 8 & 0 & 0 & 0 & 8,320 & 10,837 \\
\hline Modules.......... & 13,690 & 22,247 & 437 & 707 & 2 & 2 & 14,128 & 22,956 \\
\hline$\ldots \ldots \ldots \ldots$ & 22,002 & 33,084 & 445 & 707 & 2 & 2 & 22,448 & 33,793 \\
\hline
\end{tabular}

Source: Energy Information Administration, Form EIA-63B, "Annual Photovoltaic Module/Cell Manufacturers Survey."

conditioning unit to process the electricity into the form needed by the application, wires and other electrical connectors, and sometimes batteries for back-up power supply. Some complex, large-scale PV systems use concentrators to focus incident insolation onto small PV cells and tracking systems to track the sun. In this report, installation materials such as the support frame and concrete foundations are not considered as part of a system. The value of systems reported in Table 33 excludes excise taxes and charges for freight, transportation, and installation. The total value of complete systems shipped in 1997 was $\$ 4.1$ million. Completesystem shipments in 1997 accounted for 200 peak kilowatts, or less than one percent of total module shipments.

\section{Industry Status}

Shipments totaling 46.4 peak megawatts were reported by 21 companies in 1997 (Table 34). Ten companies expect to introduce new crystalline-silicon module products, and 5 companies reported plans to introduce new thin-film products to the industry during 1998 (Table 35). One company reported plans to produce new PV concentrator products while another plans new nonmodule system components during 1998.

Employment in PV-related activities totaled 1,736 person-years in 1997 (Tables 26 and 34), an increase of 36 percent from the 1996 level of employment and slightly greater than the increase in shipments. The average employment per company was 82 person-years in 1997, compared with 51 person-years in 1996.

Many companies engaged in the manufacture and/or importation of PV cells and modules reported that they also are involved in other PV-related activities. There were 13 companies involved in cell manufacturing, 2 more than in 1996 (Table 36). There were 18 companies involved in module or system design, 14 were active in developing module prototypes, and 10 developed PV system prototypes. There were 15 companies that sold wholesale while 4 sold retail. Five companies installed PV cells or modules in 1997, 4 less than in 1996. 
Table 32. Destination of U.S. Photovoltaic Cell and Module Export Shipments by Country, 1997

\begin{tabular}{|c|c|c|}
\hline Destination & Peak Kilowatts & Percent of U.S. Exports \\
\hline \multicolumn{3}{|l|}{ Africa } \\
\hline Angola $\ldots \ldots \ldots \ldots \ldots \ldots \ldots \ldots$ & 1.6 & * \\
\hline Burkina Faso . . . . . . . . . . . . . . & 0.1 & * \\
\hline Egypt $\ldots \ldots \ldots \ldots \ldots \ldots \ldots \ldots$ & 291.0 & 0.9 \\
\hline Morocco $\ldots \ldots \ldots \ldots \ldots \ldots \ldots \ldots \ldots$ & 285.4 & 0.8 \\
\hline Nigeria $\ldots \ldots \ldots \ldots \ldots \ldots$ & 1.6 & * \\
\hline South Africa $\ldots \ldots \ldots \ldots \ldots$ & 938.7 & 2.8 \\
\hline Uganda $\ldots \ldots \ldots \ldots \ldots \ldots \ldots$ & 0.1 & \\
\hline 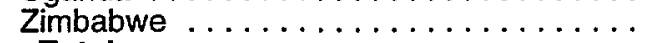 & 134.5 & 0.4 \\
\hline Total $\ldots \ldots \ldots \ldots \ldots \ldots \ldots$ & $1,653.0$ & 4.9 \\
\hline \multicolumn{3}{|l|}{ Asia and the Middle East } \\
\hline China .............. & 0.1 & * \\
\hline$\ldots \ldots \ldots$ & 0.4 & $*$ \\
\hline Hong Kong ........ & $1,423.3$ & 4.2 \\
\hline India $\ldots \ldots \ldots \ldots \ldots \ldots \ldots \ldots$ & 285.0 & 0.8 \\
\hline 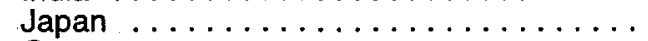 & $8,056.0$ & 23.9 \\
\hline$\ldots \ldots \ldots \ldots \ldots \ldots \ldots$ & 240.0 & 0.7 \\
\hline Philippines . . . . . . . . . . . . . & 8.7 & $*$ \\
\hline 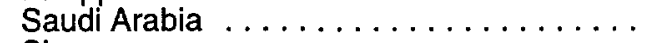 & 28.8 & 0.1 \\
\hline Singapore $\ldots \ldots \ldots \ldots \ldots \ldots \ldots \ldots$ & $1,106.4$ & 3.3 \\
\hline Thailand $\ldots \ldots \ldots \ldots \ldots \ldots \ldots \ldots$ & 182.0 & 0.5 \\
\hline 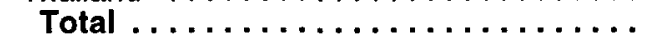 & $11,330.6$ & 33.5 \\
\hline Australia .................. & 61.2 & 0.2 \\
\hline \multicolumn{3}{|l|}{ Europe } \\
\hline$\ldots \ldots \ldots \ldots \ldots$ & 1.6 & * \\
\hline England $\ldots \ldots \ldots \ldots \ldots \ldots \ldots$ & 103.0 & 0.3 \\
\hline Finland $\ldots \ldots \ldots \ldots \ldots \ldots \ldots$ & 527.0 & 1.6 \\
\hline France $\ldots \ldots \ldots \ldots \ldots \ldots \ldots$ & 136.1 & 0.4 \\
\hline Germany . . . . . . . . . . . . . & $11,162.0$ & 33.0 \\
\hline 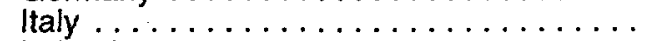 & 62.0 & 0.2 \\
\hline$\ldots \ldots \ldots \ldots$ & 667.4 & 2.0 \\
\hline$\ldots \ldots \ldots \ldots \ldots \ldots \ldots$ & 369.8 & 1.1 \\
\hline$\ldots \ldots \ldots \ldots \ldots \ldots$ & 651.0 & 1.9 \\
\hline Sweden $\ldots \ldots \ldots \ldots \ldots \ldots \ldots \ldots \ldots \ldots$ & 347.1 & 1.0 \\
\hline Switzerland $\ldots \ldots \ldots \ldots \ldots \ldots \ldots \ldots$ & 31.0 & 0.1 \\
\hline 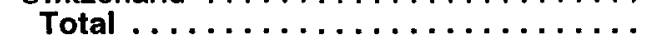 & $14,057.9$ & 41.6 \\
\hline \multicolumn{3}{|l|}{ North America } \\
\hline Canada $\ldots . . . \ldots$ & 774.6 & 2.3 \\
\hline Dominican Republic . . . . . . . . . . . & 48.4 & 0.1 \\
\hline Мexico $\ldots \ldots \ldots \ldots \ldots \ldots$ & $1,318.7$ & 3.9 \\
\hline Total $\ldots \ldots \ldots \ldots \ldots \ldots \ldots$ & $2,141.7$ & 6.3 \\
\hline \multicolumn{3}{|l|}{ South America } \\
\hline Argentina $\ldots \ldots \ldots \ldots \ldots \ldots \ldots$ & 476.3 & 1.4 \\
\hline Bolivia $\ldots \ldots \ldots \ldots \ldots \ldots \ldots \ldots$ & 2.2 & \\
\hline Brazil . . . . . . . . . . . . . . & $1,259.0$ & 3.7 \\
\hline$\ldots \ldots \ldots \ldots \ldots \ldots$ & 168.0 & 0.5 \\
\hline Columbia $\ldots \ldots \ldots \ldots \ldots \ldots \ldots \ldots$ & 349.4 & 1.0 \\
\hline Costa Rica $\ldots \ldots \ldots \ldots \ldots \ldots \ldots \ldots \ldots$ & 0.1 & * \\
\hline Ecuador $\ldots \ldots \ldots \ldots \ldots \ldots \ldots \ldots \ldots$ & 60.7 & 0.2 \\
\hline Nicaragua $\ldots \ldots \ldots \ldots \ldots \ldots$ & 0.1 & $*$ \\
\hline Panama ..................... & 30.0 & 0.1 \\
\hline 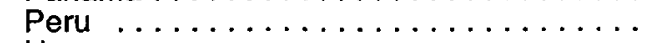 & 608.6 & 1.8 \\
\hline Uruguay $\ldots \ldots \ldots \ldots \ldots \ldots$ & 1.0 & * \\
\hline venezuela $\ldots \ldots \ldots \ldots \ldots \ldots$ & 1.0 & * \\
\hline Other Latin America . . . . . . . . . . . . . . & 60.0 & 0.2 \\
\hline Total $\ldots \ldots \ldots \ldots \ldots \ldots \ldots \ldots \ldots$ & $3,016.4$ & 8.9 \\
\hline Other $\ldots \ldots \ldots \ldots$ & $1,532.2$ & 4.6 \\
\hline Total U.S. Exports . . . . . . . . . . . . . & $33,793.0$ & 100.0 \\
\hline
\end{tabular}

* = Less than 0.05 percent.

Note: "Other" represents shipments to couritries not disaggregated by companies on Form EIA-63B. Totals may not equal sum of components due to independent rounding.

Source: Energy Information Administration, Form ElA-63B, "Annual Photovoltaic Module/Cell Manufacturers Survey." 
Table 33. Shipments of Complete Photovoltaic Module Systems, 1995-1997

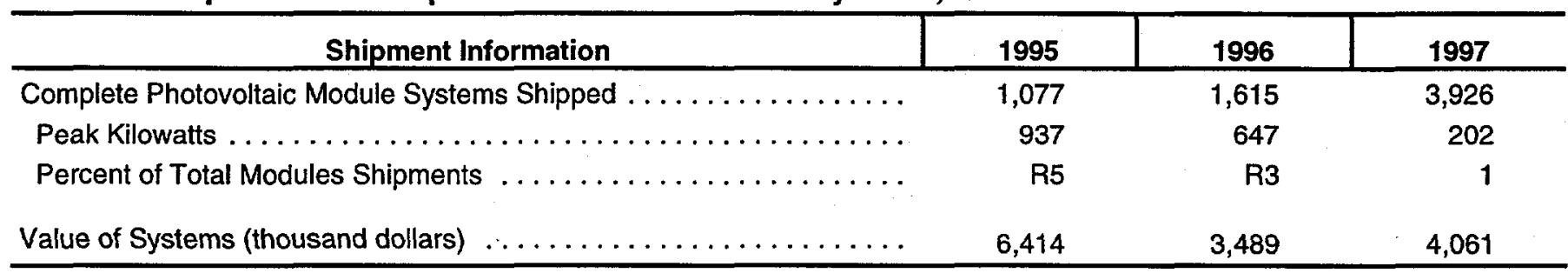

$R=$ Revised.

Source: Energy Information Administration, Form EIA-63B, "Annual Photovoltaic Module/Cell Manufacturers Survey."

Table 34. Employment in the Photovoltaic Manufacturing Industry, 1991-1997

\begin{tabular}{|c|c|c|c|}
\hline & Year & $\begin{array}{l}\text { Number of } \\
\text { Companies }\end{array}$ & $\begin{array}{c}\text { Number of } \\
\text { Person-Years }\end{array}$ \\
\hline 1991 & $\ldots \ldots$ & 23 & 1,588 \\
\hline 1992 & & 21 & 1,463 \\
\hline 1993 & & 19 & 1,431 \\
\hline 1994 & $\ldots \ldots$ & 22 & 1,312 \\
\hline 1995 & $\ldots \ldots \ldots \ldots$ & 24 & 1,578 \\
\hline 1996 & $\ldots \ldots \ldots$ & 25 & 1,280 \\
\hline 1997 & & 21 & 1,736 \\
\hline
\end{tabular}

Source: Energy Information Administration, Form EIA63B, "Annual Photovoltaic Module/Cell Manufacturers Survey."
Table 35. Companies Expecting To Introduce New Photovoltaic Products in 1998

\begin{tabular}{|c|c|}
\hline New Product Type & $\begin{array}{l}\text { Number of } \\
\text { Companies }\end{array}$ \\
\hline \multicolumn{2}{|l|}{ Crystalline Silicon } \\
\hline Single-Crystal Silicon Modules . . . . . . & 4 \\
\hline Cast Silicon Modules . . . . . . . . . . & 2 \\
\hline Ribbon Silicon Modules . . . . . . . . . . & 4 \\
\hline \multicolumn{2}{|l|}{ Thin Film } \\
\hline Amorphous Silicon Modules . . . . . . & 4 \\
\hline Other (Thin-Film) $\ldots \ldots \ldots \ldots \ldots$ & 1 \\
\hline Other (Flat Plate) . . . . . . . . . . . . & 0 \\
\hline Concentrators $\ldots \ldots \ldots \ldots \ldots \ldots$ & 1 \\
\hline Nonmodule System Components . . . . . . & 1 \\
\hline
\end{tabular}

Source: Energy Information Administration, Form EIA-63B, "Annual Photovoltaic Module/Cell Manufacturers Survey."

Table 36. Number of Companies Involved in Photovoltaic-Related Activities, 1996 and 1997

\begin{tabular}{|c|c|c|}
\hline \multirow[b]{2}{*}{ Type of Activity } & \multicolumn{2}{|c|}{$\begin{array}{l}\text { Number of } \\
\text { Companies }\end{array}$} \\
\hline & 1996 & 1997 \\
\hline Cell Manufacturing . . . . . . . . . . & 11 & 13 \\
\hline Module or System Design & 19 & 18 \\
\hline Prototype Module Development . . & 15 & 14 \\
\hline Prototype Systems Development . & 14 & 10 \\
\hline Wholesale Distribution & 19 & 15 \\
\hline Retail Distribution . . . . . . . . . & 10 & 4 \\
\hline Installation $\ldots \ldots \ldots \ldots \ldots$ & 9 & 5 \\
\hline \multicolumn{3}{|l|}{ Noncollector System } \\
\hline Component Manufacturing . . . . . & 6 & 4 \\
\hline
\end{tabular}

Source: Energy Information Administration, Form EIA-63B,

"Annual Photovoltaic Module/Cell Manufacturers Survey." 



\section{Survey of Geothermal Heat Pump Shipments}

\section{Introduction}

This chapter provides information on geothermal heat pump shipments, based on the Energy Information Administration's (EIA) Form EIA-902, "Annual Geothermal Heat Pump Manufacturers Survey." It begins with a general discussion of heat pumps, followed by a discussion of the survey results and some salient characteristics of the data, and ends with a technical discussion of heat pump operation.

\section{Overview}

"Heat pump" is a term applied to a machine that can transfer heat both to and from a source. Therefore, a heat pump can be used both for space heating in the winter and for cooling (air conditioning) in the summer. The most common type of heat pump for domestic use is the air-to-air (air source) system in which heat is taken from air (heat source) at one location and transferred to air (heat sink) at another location.

Another type of heat pump transfers heat from air to water and has been designed for domestic hot-water heating. Geothermal heat pumps are a special type of air-to-water heat pump that use the earth as a heat source or sink, depending on the season. Since the earth's temperature a few feet below the surface stays relatively constant (about 55 degrees Fahrenheit) year round, one can extract heat from the earth when the air temperature is below the earth's temperature (winter), and transfer heat to the earth when the air temperature is above the in-ground temperature (summer). Geothermal heat pumps are generally more expensive to install but more efficient (costing less to operate and maintain) than an air-to-air heat pump. The technical section at the end of this chapter further explains the operation and rating of heat pumps.

\section{EIA Survey of Geothermal Heat Pumps}

The Energy Information Administration's (EIA) new survey, Form EIA-902, "Annual Geothermal Heat Pump Manufacturers Survey," shows that manufacturers shipped almost 58,000 geothermal heat pumps in 1997 and over 213,000 during the period 1994 through 1997. The survey was completed by approximately 18 known domestic manufacturers of geothermal heat pumps. Data from the survey are collected under a confidentiality provision. As a result, only aggregated statistics are released. The Form EIA-902 tracks shipments of the three main types of geothermal heat pumps, as certified by the Air Conditioning and Refrigeration Institute (ARI), and a small volume of nonARI rated heat pumps (Tables 37-40). The three ARIrated classifications for geothermal heat pumps are as follows:

- ARI-320, Water-Source Heat Pumps (WSHP). These systems are installed in commercial buildings, where a central chiller or boiler supplies chilled or heated water, respectively, to heat pumps installed in series. The heat pumps reject building heat to chilled water during the cooling season and, during the heating season, take heat from boiler water;

- ARI-325, Ground Water-Source Heat Pumps (GWHP). The GWHP is an open-loop system in which ground water is drawn from an aquifer or other natural body of water into piping. At the heat pump, heat is drawn from or dumped into the water through a heat exchanger to the refrigerant in the heat pump. The heated or cooled water returns to its source; and

- ARI-330, Ground-Source Closed-Loop Heat Pumps (GSHP). A water or water/glycol (antifreeze) solution flows continuously through a closed loop of pipe buried underground. Ground heat is absorbed into or rejected from the solution flowing in the closed loop. At the heat pump, heat is drawn from or dumped to the closed loop solution via heat transfer through a heat exchanger, which passes heat to, or removes heat from, the refrigerant in the heat pump.

Manufacturers shipped nearly 58,000 heat pumps of all types in 1997 (Table 37) compared with about 52,000 in 1996-an increase of almost 13 percent. Of those shipped in 1997, over 28,000 were ARI-320 rated, 9,700 were 
Table 37. Geothermal Heat Pump Shipments by Model Type 1994-1997

(Number of Units)

\begin{tabular}{|c|c|c|c|c|}
\hline Model Type & 1994 & 1995 & 1996 & 1997 \\
\hline ARI-320 & 26,757 & 26,787 & 24,832 & 28,260 \\
\hline ARI-325 & 5,924 & 8,615 & 7,603 & 9,724 \\
\hline ARI-330 & 16,023 & 18,185 & 18,094 & 18,611 \\
\hline Non-ARI Rated & 757 & 838 & 991 & 1,327 \\
\hline Totals $\ldots \ldots \ldots \ldots \ldots$ & 49,461 & 54,425 & 51,520 & 57,922 \\
\hline
\end{tabular}

Note: Data for ARI-320 units are subject to substantial revision. See Appendix B.

Source: Energy Information Administration, Form EIA-902 "Annual Geothermal Heat Pump Manufacturers Survey."

Table 38. Capacity of Geothermal Heat Pump Shipments by Model Type, 1994-1997 (Total Rated Capacity in Tons)

\begin{tabular}{c|r|r|r|r}
\hline Model Type & $\mathbf{1 9 9 4}$ & $\mathbf{1 9 9 5}$ & \multicolumn{1}{c}{$\mathbf{1 9 9 6}$} & \multicolumn{1}{c}{1997} \\
\hline ARI-320 $\ldots \ldots \ldots \ldots \ldots \ldots$ & 73,879 & 72,304 & 78,391 & 92,116 \\
ARI-325 $\ldots \ldots \ldots \ldots \ldots \ldots$ & 29,003 & 39,672 & 28,705 & 37,049 \\
ARI-330 $\ldots \ldots \ldots \ldots \ldots \ldots$ & 63,101 & 74,253 & 64,114 & 73,137 \\
Non-ARI Rated $\ldots \ldots \ldots \ldots$ & 2,879 & 3,935 & 5,091 & 6,662 \\
Totals $\ldots \ldots \ldots \ldots \ldots$ & $\mathbf{1 6 8 , 8 6 2}$ & 190,164 & $\mathbf{1 7 6 , 3 0 1}$ & $\mathbf{2 0 8 , 9 6 4}$ \\
\hline
\end{tabular}

Note: A capacity of one ton equals 12,000 Btu's. Data for ARI-320 units are subject to substantial revision. See Appendix B. Source: Energy Information Administration, Form EIA-902 "Annual Geothermal Heat Pump Manufacturers Survey."

ARI-325 rated, 18,600 were ARI-330 rated, and approximately 1,300 were non-ARI-rated units.

The total rated capacity of heat pumps shipped in 1997 was almost 209,000 tons (Table 38). The average rated capacity of heat pumps shipped in 1997 was 3.6 tons compared to 3.4 tons in 1996. Average capacily increased for all ARI-rated geothermal heat pumps. ARI-320 units tend on average to be smaller at 3.3 tons per unit than ARI-325 or ARI-330 units at almost 4 tons per unit and non-ARI-rated units at 5 tons per unit. Ey comparison, a typical home central air conditioner has a rating of 3.0 tons. These results may indicate a niche market for larger geothermal heat pumps, where the savings in operating costs are greater than the higher initial investment for geothermal heat pumps.

The proportion of geothermal heat pumps shipped to each Census region in 1997 was as follows: the South (46 percent), the Midwest (23 percent), the Northeast ( 16 percent), the West 10 percent, and exports 4 percent (Table 39). The Northeast accounted for the greatest increase in units-up nearly 2,900 units in 1997 compared to 1996. In terms of the number of units and percentage of units, export shipments showed the greatest decline, falling 41 percent to just over 2,400 units in 1997. About 50 percent of total geothermal heat pumps were shipped to wholesalers (Table 40) of which nearly 40 percent were ARI-320 rated. Forty-four percent of geothermal heat pump shipments went to installers of which 58 percent were ARI-320 rated. Retail distributors represented less than 1 percent of heat pump shipments.

\section{Consumer Awareness}

Collaborative alliances among government organizations, the Geothermal Heat Pump Consortium, the International Ground Source Heat Pump Association, and the geothermal heat pump industry have expanded consumer awareness and acceptance of geothermal heat pumps. Such efforts have resulted in increased installation of geothermal heat pumps where electric utilities and electric service companies provide attractive financing, rebates, guaranteed utility rates, shared savings contracts, and/or equipment leasing arrangements.

\section{How Heat Pumps Work}

A heat pump is a device that operates on the concept of heat transfer from areas of lower temperature to areas of higher temperature--the reverse of normal heat flow. It 
Table 39. Geothermal Heat Pump Shipments by Exports, Census Region, and Model Type, 1996 and 1997 (Number of Units)

\begin{tabular}{|c|c|c|c|c|c|}
\hline \multicolumn{6}{|c|}{1996} \\
\hline \multirow{2}{*}{$\begin{array}{c}\text { Exports and Census } \\
\text { Region }\end{array}$} & \multicolumn{4}{|c|}{ Model Type } & \multirow[b]{2}{*}{ Total } \\
\hline & ARI-320 & ARI-325 & ARI-330 & Non-ARI Rated & \\
\hline$\ldots \ldots \ldots \ldots \ldots \ldots$ & 3,103 & 302 & 624 & 61 & 4,090 \\
\hline Midwest . . . . . . . . . . & 2,467 & 2,295 & 6,804 & 308 & 11,874 \\
\hline Northeast . . . . . . . . . . & 2,572 & 1,001 & 2,774 & 70 & 6,417 \\
\hline South $\ldots \ldots \ldots \ldots \ldots$ & 14,138 & 3,834 & 6,880 & 450 & 25,302 \\
\hline West $\ldots \ldots \ldots \ldots$ & 2,552 & 171 & 1,012 & 102 & 3,837 \\
\hline Total $\ldots \ldots \ldots \ldots$ & 24,832 & 7,603 & 18,094 & 991 & 51,520 \\
\hline \multicolumn{6}{|c|}{1997} \\
\hline \multirow{2}{*}{$\begin{array}{c}\text { Exports and Census } \\
\text { Region } \\
\end{array}$} & \multicolumn{4}{|c|}{ Model Type } & \multirow[b]{2}{*}{ Total } \\
\hline & ARI-320 & ARI-325 & ARI-330 & Non-ARI Rated & \\
\hline Exports $\ldots \ldots \ldots \ldots \ldots$ & 1,825 & 101 & 437 & 64 & 2,427 \\
\hline Midwest .............. & 3,413 & 2,717 & 6,780 & 492 & 13,402 \\
\hline Northeast $: \ldots \ldots \ldots \ldots$ & 5,082 & 1,512 & 2,593 & 93 & 9,280 \\
\hline South ............... & 15,332 & 4,015 & 6,828 & 613 & 26,788 \\
\hline West $\ldots \ldots \ldots \ldots \ldots$ & 2,608 & 1,379 & 1,973 & 65 & 6,025 \\
\hline Total $\ldots \ldots \ldots \ldots \ldots$ & 28,260 & 9,724 & 18,611 & 1,327 & 57,922 \\
\hline
\end{tabular}

Note: The Midwest Census region consists of Illinois, Indiana, lowa, Kansas, Michigan, Minnesota, Missouri, Nebraska, North Dakota, Ohio, South Dakota, and Wisconsin. The Northeast Census region consists of Connecticut, Maine, Massachusetts, New Hampshire, New Jersey, New York, Pennsylvania, Rhode Island, and Vermont. The South Census region consists of Alabama, Arkansas, Delaware, District of Columbia, Florida, Georgia, Kentucky, Louisiana, Maryland, Mississippi, North Carolina, Oklahoma, South Carolina, Tennessee, Texas, Virginia, and West Virginia. The West Census region consists of Alaska, Arizona, California, Colorado, Hawaii, Idaho, Montana, Nevada, New Mexico, Oregon, Utah, Washington, and Wyoming. Data for ARI-320 units are subject to substantial revision. See Appendix $B$.

Source: Energy Information Administration, Form EIA-902 “Annual Geothermal Heat Pump Manufacturers Survey.”

employs a refrigeration cycle during which a refrigerant (known as the "working fluid") is compressed (as a liquid) then expanded (as a vapor) to absorb and release heat, respectively. Specifically, the heat pump absorbs from an outside medium (air, ground, groundwater) and then transfers ("pumps") the heat to a space to be heated during the winter season. By reversing the process, the heat pump extracts (absorbs) heat from the same space during the summer season, and then transfers it to the outside air. It also acts as a dehumidifier, removing moisture from the air and making it more comfortable.

\section{Air Source Heat Pumps}

An air-source heat pump-the most common type of heat pump-absorbs heat from the outside air and transfers the heat through the working fluid to the space to be heated. In the heating mode, however, air-source heat pumps lose efficiency and generally require a backup heating system when the outside air approaches $32^{\circ}$
F or less. In the cooling mode, the heat pump absorbs heat through the working fluid from the space to be cooled and rejects the heat to the outside air.

\section{Geothermal (Groundwater) Heat Pumps}

In a geothermal heat pump, the refrigerant exchanges heat with a fluid circulating through piping in contact with the earth. The fluid circulates in a variety of loop (pipe) configurations, depending on the temperature of the ground. Loops may be installed horizontally or vertically in the ground or submersed in a body of water (Figure 12). Although the fluid in most types of loop configurations circulates in a closed system, open loops (normally vertical systems) are sometimes used when a sufficient supply of water is available from wells.

The efficiency of a heat pump-measured by the electrical energy required for the working fluid to absorb and reject a certain amount of heat-is directly related to 
Table 40. Geothermal Heat Pump Shipments by Customer Type and Model Type, 1996 and 1997 (Number of Units)

\begin{tabular}{|c|c|c|c|c|c|}
\hline \multicolumn{6}{|c|}{1996} \\
\hline Customer Type & ARI-320 & ARI-325 & ARI-330 & Non-ARI Rated & Total \\
\hline Exporter & W & W & w & 57 & 2,276 \\
\hline Wholesale Distributor . . . . . & 10,929 & 2,980 & 7,346 & 189 & 21,444 \\
\hline Retail Distributor $\ldots \ldots \ldots$ & w & W & 7,267 & 273 & 8,336 \\
\hline Installer $\ldots \ldots \ldots \ldots \ldots$ & 12,256 & 3,285 & 2,755 & 466 & 18,762 \\
\hline End-User $\ldots \ldots \ldots \ldots \ldots$ & 124 & W & W & W & 689 \\
\hline Others $\ldots \ldots \ldots \ldots \ldots \ldots$ & W & w & W & W & 13 \\
\hline Total ............... & 24,832 & 7,603 & 18,094 & 991 & 51,520 \\
\hline \multicolumn{6}{|c|}{1997} \\
\hline Customer Type & ARI-320 & A.RI-325 & ARI-330 & Non-ARI Rated & Total \\
\hline$\ldots \ldots \ldots \ldots \ldots$ & W & 0 & W & 0 & W \\
\hline Wholesale Distributor ...... & 11,557 & 8,226 & 9,091 & 307 & 29,181 \\
\hline Retail Distributor $\ldots \ldots \ldots$ & 0 & W & 0 & W & w \\
\hline Installer $\ldots \ldots \ldots \ldots \ldots$ & 14,620 & 1,071 & 8,820 & 791 & 25,302 \\
\hline End-User $\ldots \ldots \ldots \ldots \ldots$ & w & 0 & W & w & 657 \\
\hline Others $\ldots \ldots \ldots \ldots \ldots \ldots$ & 1,555 & w & w & W & 1,727 \\
\hline Total $\ldots \ldots \ldots \ldots \ldots \ldots$ & 28,260 & 9,724 & 18,611 & 1,327 & 57,922 \\
\hline
\end{tabular}

$W=$ Data withheld to avoid disclosure of proprietary company data. Data for ARI-320 units are subject to substantial revision. See Appendix B.

Source: Energy Information Administration, Form EIA-902 "Annual Geothermal Heat Pump Manufacturers Survey."

Figure 12. Ground Coupled Heat Pumps-Loop Configurations
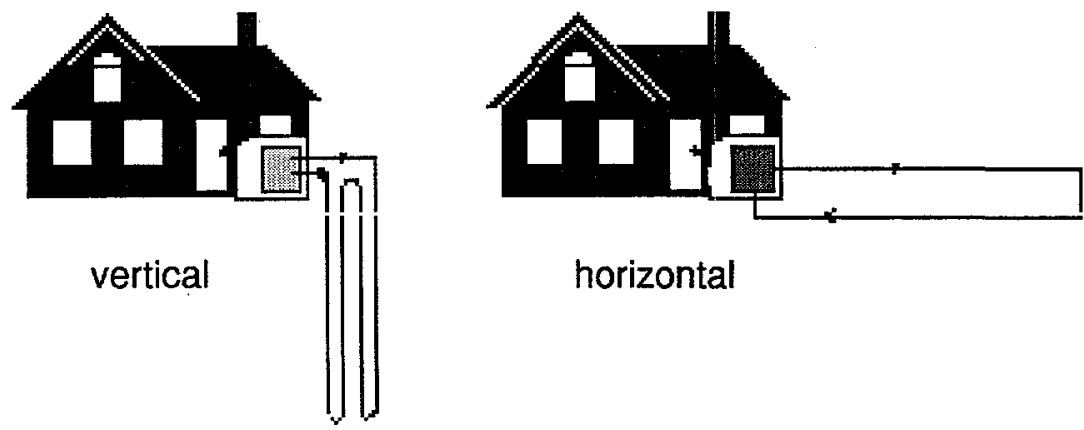

horizontal

Note: For more in-depth information on gecthermal heat pumps, visit the Geo-Heat Center's consumer information website at http://www.oit.edu.

Source: Geo-Heat Center.

the temperature differential between the ground and the fluid. In heat pump terminology, the difference between the temperature where the heat is absorbed (source) and the temperature where the heat is delivered (sink) is called the "lift." The larger the lift, the greater the power input required by the heat pump. This is the basis for the efficiency advantage of the geothermal heat pump over air-source heat pumps. Geothermal heat pumps are more efficient (a smaller "lift") than conventional heat pumps or air conditioners that use the outdoor air since the ground or ground water a few feet below the earth's surface remains relatively constant throughout the year. During the winter, heat is transferred from the relatively warm ground (approximately $55^{\circ} \mathrm{F}$ ) than from the usually much colder atmosphere, while during the summer, excess waste heat is transferred to the cooler ground rather than to the normally much warmer atmosphere. Geothermal heat pumps generally have a higher capital cost, than air-to-air heat pumps, due to the cost of installing underground piping. However, 
depending on the location, geothermal heat pumps can reduce energy consumption (operating cost) and correspondingly, air emissions, by more than 20 percent compared to high-efficiency outside air heat pumps. Geothermal heat pumps also use the waste heat from air conditioning to provide free hot water heating in the summer.

\section{Ratings of Heat Pumps}

Heat pumps are rated according to their heating or cooling capacity and their operating efficiency. The capacity of a heat pump for either heating or cooling is commonly expressed in terms of British thermal units (Btu) per hour of heat delivery or removal. The heating or cooling capacity is sometimes stated in tons, where 1 ton is equivalent to a heat delivery or removal rate of $12,000 \mathrm{Btu}$ per hour. Although an average home requires a unit of approximately $36,000 \mathrm{Btu}$ ( 3 tons), the size of a house and the quality of insulation determine the necessary heat pump capacity. An under-sized unit will not keep the house comfortable during peak heating and cooling demand times and may run continuously, resulting in high operating costs. On the other hand, an over-sized unit is more costly to purchase and operate and during cooling seasons may not run long enough, causing conditions of high humidity.

The efficiency of a heat pump or performance rating (distinct from its capacity) is useful for comparing units of the same type. The ratings used for different types of equipment are not generally comparable. Heating performance is rated by the coefficient of performance (COP)-the rate of heat delivery relative to the total rate of energy input required to operate the heat pump. The average COP of a heat pump in heating mode may be in the range 2 to 3 , meaning that heat delivered to a building is 2 to 3 times as great as the energy input required to operate the heat pump. The excess energy delivered (as heat) over the input (as electricity) is derived from the heat source-outdoor air for a conventional air source heat pump and ground or ground water for a geothermal unit). ${ }^{15}$

The COP of a heat pump is not the same in the heating and cooling modes but varies with conditions, in particular with the temperatures of the heat source and heat sink. This is important for heating, because the efficiency decreases as the temperature of the heat source decreases, i.e., the outdoor air in an air-to-air heat pump. When the outdoor air temperature falls to below about $32^{\circ} \mathrm{F}$, the efficiency of an air-to-air heat pump is so low that auxiliary heating is required. The auxiliary heating system is usually resistance heat that supplements the heat pump, though an independent gas- or oilfired furnace may be used. Electric resistance heat is very expensive and is best used as auxiliary heat or in climates where little heat is required. Hence, air-to-air heat pumps are not recommended where low winter temperatures are common and large amounts of auxiliary resistance heat are required. By comparison, geothermal heat pumps operate more efficiently by taking advantage of the fairly constant and warm temperature of the earth. Thus, they do not require auxiliary heating equipment.

The energy efficiency rating (EER) is commonly used to rate the efficiency of cooling performance. The EER in Btu per watthour is 3.412 (the Btu equivalent of a watthour) times the COP. A COP of 3 (i.e., 3.412 Btu per watthour $\times 3$ ) equals an EER of 10.2 Btu per watthour. The EER can also be defined as the cooling capacity (size in Btu/hour) divided by the wattage of the unit (i.e., $36,000 \mathrm{Btu} /$ hour $/ 3,600$ watts equals $10.0 \mathrm{Btu}$ per watthour).

The newest term used by the air conditioning and heating industry to rate the efficiency of air conditioners and heat pumps is "Seasonal Energy Efficiency Rating" (SEER). While both the COP and EER values are valid only at specific test conditions used in the rating, the SEER is based on average or typical operating conditions.

Because of advances in technology and design, newer units have a SEER rating as high as 15 or 16 . The Federal Government now requires new air conditioners and heat pumps to have a SEER of at least 10 . Units that are 10 or more years old probably have a SEER of 10 or less. A new unit with a SEER of 12 will be one-third more efficient than an older unit with a SEER of $8 .{ }^{16}$ In air-to-air heat pumps, when the outside air is below average temperatures (heat source) during the heating season or above average temperatures (heat sink) during the cooling season, the unit will not operate at the design SEER. Geothermal heat pumps that take advantage of the relatively constant temperature of the earth will be able to operate at the design SEER over wider temperature variations in the air.

15 The heat in the outdoor air is derived from the sun, so that an air-to-air heat pump makes use of solar energy.

16 To pump a specified amount of energy, in this example 24, two heat pumps with a SEER rating of 8 and 12 will require 3 and 2 units of input energy respectively, resulting in the heat pump with the SEER rating of 12 saving one-third the energy used by the less efficient unit. 



\section{Appendix A}

\section{EIA Renewable Energy Data Sources}

The Energy Information Administration (ELA) develops renewable energy information from a wide variety of sources, cutting across different parts of the organization. This appendix provides a list of all sources which the EIA uses to obtain renewable energy information. While most data come from EIA data collection forms, some are derived from secondary sources. For EIA data collections, additional information is available in the EIA publication Directory of Energy Data Collection Forms 1996, DOE/EIA-0249(96), December 1996, or through the EIA home page.

\section{EIA-63A/B, "Annual Solar Thermal Collector Manufacturers Survey" and "Annual Photovoltaic Module/Cell Manufacturers Survey"}

Energy Sources: Solar energy.

Energy Functions: Disposition.

Frequency of Collection: Annually.

Respondent Categories: Solar thermal collector manufacturers and/or importers; photovoltaic module/cell manufacturers and/or importers;

Reporting Requirement: Mandatory.

Description: Forms EIA-63A/B are designed to gather for publication data on shipments of solar thermal collectors and photovoltaic modules. Data are collected by end use and market sector. Collector types include low-temperature, medium-temperature air, mediumtemperature liquid, thermosiphon, flat plate, concentrator, integral collector storage, and evacuated tube and concentrators. Respondents are manufacturers, importers, and exporters of solar thermal collectors and photovoltaic modules. These forms were formerly known as CE-63A/B.

\section{EIA-457A/H, "Residential Energy Consumption Survey"}

Energy Sources: Coal and coal products; electricity; natural gas; petroleum and petroleum products; wood. Energy Functions: Consumption costs and/or prices.
Frequency of Collection: Triennially.

Respondent Categories: Electric utilities; natural gas distributors (including importers/exporters); petroleum and petroleum product distributors; institutions (nonprofit); individuals/households.

Reporting Requirement: Voluntary and mandatory. Description: Forms EIA-457A through $\mathrm{G}$ are used to collect comprehensive national and regional data on both the consumption of and expenditures for energy in the residential sector of the economy. Data are used for analyzing and forecasting residential energy consumption. Housing, appliance, and demographic characteristics data are collected via personal interviews with households, and consumption and expenditure billing data are collected from the energy suppliers. Enduse intensities are produced for space heating, water heating, air conditioning, refrigerators, and appliances. Rental agents are contacted by telephone to check on fuels used in rented apartments. Surveys were conducted in 1978, 1979, 1980, 1981, 1982, 1984, 1987, 1990, and 1993. Form EIA-457H is used to collect detailed lighting usage information for a subsample.

\section{EIA-819M, "Monthly Oxygenate Telephone Report"}

Energy Sources: Petroleum and petroleum products Energy Functions: Production, Supply Frequency of Collection: Monthly

Respondent Categories: Oxygenate producers, Petroleum and petroleum product distributors, Petroleum and petroleum product processors, Petroleum and petroleum product storers

Reporting Requirement: Mandatory

Legal Citation: Public Law 93-275 (FEAA), 13(b), 5(a), 5 (b), 52

Description: Form ElA-819M is designed to obtain information on oxygenate production, imports, and endof-month stocks. Data was previously collected using the EIA-819, Monthly Oxygenate Telephone Survey Data are reported by oxygenate type and PAD District. Respondents are a sample of: operators of facilities that produce oxygenates; operators of petroleum refineries; 
operators of bulk terminals, bulk stations, blending plants, and other non-refinery facilities that store or blend oxygenates; and importers of oxygenates.

\section{ElA-846 (A,B,C), "Manufacturing Energy Consumption Survey"}

Energy Sources: Coal and coal products; electricity; natural gas; petroleum and petroleum products; wood. Energy Functions: Consumption; disposition; financial; and/or management; production; research and development; other energy functions.

Frequency of Collection: Triennially.

Respondent Categories: Manufacturing.

Reporting Requirement: Mandatory.

Description: Forms EIA-846A through D are used to collect information on energy consumption, energy usage patterns, and fuel-switching capabilities of the manufacturing sector of the U.S. economy. The information from this survey is used to publish aggregate statistics on the consumption of energy for fuel and nonfuel purposes; fuel-switching capabilities; and certain energy-related issues such as energy prices, on-site electricity generation, and purchases of electricity from nonutilities. Since 1991, the survey has also collected information on end users of energy, participation in energy management programs, and penetration of new technology. Respondents are a sample of manufacturing establishments in Standard Industrial Classification categories 20 through 39.

\section{EIA-860, "Annual Electric Generator Report"}

Energy Sources: Electricity.

Energy Functions: Financial and/or management; production.

Frequency of Collection: Annually.

Respondent Categories: Electric utilities.

Reporting Requirement: Mandatory.

Description: Form EIA-860 is used to collect data on the status of electric generating plants and associated equipment in operation and those scheduled to be in operation in the United States within 10 years of filing of the report. These data are used to maintain and update EIA's electric power plant frame data base. Data are collected on power plant sites, and the design data of electric generators. Respondents include each electric utility that operates, or plans to operate, a power plant in the United States within 10 years of the report.

\section{EIA-861, "Annual Electric Utility Report”}

Energy Sources: Electricity.

Energy Functions: Disposition; financial and/or management; production.

Frequency of Collection: Annually.

Respondent Categories: Electric utilities.

Reporting Requirement: Mandatory.

Description: Form EIA-861 is a mandatory collection of data, filed annually by each electric utility in the United States, its territories, and Puerto Rico. The survey collects data on generation, wholesale purchases, and sales and revenue by class of consumer and State. These data are used to maintain and update the EIA's electric utility frame data base. This data base provides information to answer questions from the Executive Branch, Congress, other public agencies, and the general public. Respondents include each electric utility that is a corporation, person, agency, authority, or other legal entity or instrumentality that owns or operates facilities within the United States, its territories, or Puerto Rico for the generation, transmission, distribution, or sale of electric energy primarily for use by the public.

\section{EIA-867, “Annual Nonutility Power Producer Report"}

Energy Sources: Electricity.

Energy Functions: Production.

Frequency of Collection: Annually.

Respondent Categories: Nonutility power producers.

Reporting Requirement: Mandatory.

Description: Form EIA-867 is used to collect data annually from nonutility power producers who own or plan on installing electric generation equipment with a total capacity of one megawatt or more at an existing or proposed site. Electricity generation, installed capacity, and energy consumption data are collected. These data will be used to augment existing electric utility data and for electric power forecasts and analyses.

\section{EIA-871A/F, "Commercial Buildings Energy Consumption Survey"}

Energy Sources: Electricity; natural gas; natural gas products; petroleum and petroleum products; wood; other energy sources.

Energy Functions: Consumption; costs and/or prices.

Frequency of Collection: Triennially. 
Respondent Categories: Commercial buildings; electric utilities; natural gas distributors (including importers/exporters); petroleum and petroleum product distributors; other (industry); Federal government institutions (nonprofit).

Reporting Requirement: Voluntary and mandatory. Description: Forms EIA-871A through $\mathrm{F}$ are used to collect information for the Commercial Buildings Energy Consumption Survey (CBECS). The survey provides comprehensive national and regional information on the consumption of, and expenditures for, energy in the commercial sector of the economy. Data are used in EIA models and published in statistical and analytical reports. Physical characteristics information for commercial buildings is collected by personal interviews with building owners and managers using Form EIA871A. Billing and consumption data for the buildings are collected by mail from individual energy suppliers by using Forms EIA-871C through $\mathrm{F}$ (depending upon the energy source). Supplemental information on construction improvements, maintenance, and repairs is collected for the Bureau of the Census by using Form EIA-871G. This survey was renamed the CBECS in 1989. Previously it was conducted under the name of Nonresidential Buildings Energy Consumption Survey.

\section{EIA-902, "Annual Geothermal Heat Pump Manufacturers Survey"}

Energy Sources: Geothermal.

Energy Functions: Disposition.

Frequency of Collection: Annually.

Respondent Categories: Geothermal heat pump manufacturers and importers.

Reporting Requirement: Mandatory.

Description: The Form EIA-902 collects information on shipments of geothermal heat pumps. The survey tracks shipments of the following three main types of geothermal heat pumps, as classified by the Air Conditioning \& Refrigeration Institute (ARI), and the much smaller shipped volume of non-ARI rated systems. A brief description of the ARI-classified system is as follows:

ARI320-Water-Source Heat Pumps (WSHP)-These systems are installed in commercial buildings, where a central chiller or boiler supplies chilled or heated water, respectively, to heat pumps installed in series. The heat pumps reject building heat to chilled water during the cooling season and, during the heating season, take heat from boiler water.

ARI 325-Ground Water-Source Heat Pumps (GWHP)-The GWHP is an open-loop system in which ground water is drawn from an aquifer or other natural body of water into piping. At the heat pump, heat is drawn from or dumped to the water through a heat exchanger to the refrigerant in the heat pump. The heated or cooled water returns to its source.

ARI 330-Ground Source Closed-Loop Heat Pumps (GSHP)-A water or water/glycol (antifreeze) solution flows continuously through a closed loop of pipe buried underground. Ground heat is absorbed into or rejected from the solution flowing in the closed loop. At the heat pump, heat is drawn from or dumped to the closed loop solution via heat transfer through a heat exchanger, which passes heat to or removes heat from the refrigerant in the heat pump. Depending on the type of ground and land area, systems can either be installed horizontally or vertically.

Data are collected by model type, heat pump capacity, region of destination, customer type, and economic sector. Respondents are manufacturers and importers. 



\section{Appendix B}

\section{Renewable Data Limitations}

This appendix provides information about the quality of renewable energy data presented in this report. Information pertinent to renewable energy source data quality, in general, is presented first, followed by discussion of electric and non-electric data sources by fuel type.

Renewable energy projects pose special challenges when attempting to collect complete information on them. One challenge is the dispersed nature of many renewable energy forms, such as a photovoltaic (PV) system for generating electricity that may operate in a "standalone" fashion in a remote location. If the facility is not connected to an electricity grid, there is no Federal regulatory requirement to report its operating information. Tracking down hundreds or thousands of such facilities, each with a small power output, can be extremely challenging.

Another challenge involves tracking renewable energy supplies. Conventional energy supplies, such as petroleum, are easily tracked because the distribution networks (usually pipelines) are limited and well-defined. This permits one to make reasonable assumptions about fuel consumption, assuming stocks can be reasonably estimated. ${ }^{17}$ The same cannot be said for many renewable energy supplies. Often a large number of energy consumers must be surveyed in order to make reasonable inferences about renewable energy consumption. Wood, for example, is gathered by tens of thousands of entities-millions if residential use is considered-for fuel uses not reportable for regulatory purposes. Thus, obtaining accurate data on wood energy consumption would entail conducting large end use consumption surveys.

Finally, some renewable energy sources are byproducts (such as pulping liquor) of non-energy processes. To track such uses, information must be solicited from respondents not generally in the energy supply chain.

\section{Electricity ${ }^{18}$}

As noted in Chapter 1, 69 percent of renewable energy consumption measured by EIA is used to produce electric power. It is, therefore, important to examine the coverage quality of EIA renewable electricity data. EIA renewable electricity generation is derived from two principal sources: Form EIA-759, "Monthly Power Plant Report," and Form EIA-867, "Annual Nonutility Power Producer Report." Form EIA-759 is sent to all utilities, while the EIA-867 is required of all nonutility generating facilities exceeding 1 megawatt capacity. (This includes facilities which meet Federal Energy Regulatory Commission [FERC] standards as a "qualifying facility" [QF], as well as independent power producers [IPPs]). Therefore, off-grid electric applications are not captured here (although they may be covered in EIA's Manufacturing Energy Consumption Survey ${ }^{19}$ ).

Because electric utilities are easily identified, seldom change business status, and have mandatory regulatory reporting requirements, complete coverage of utilitygenerated electricity is virtually assured. In contrast, nonutilities (i.e., QFs and IPPs) are required only to file regulatory reports at the time of their intention to become a grid electricity-producing facility. Over time, $\mathrm{QF}$ ownerships and locations change frequently. These factors, combined with the large number of QF applications, make tracking these facilities difficult. Accordingly, EIA has developed a threshold below which nonutility units are not surveyed. Form EIA- 867 is a mandatory survey of all existing and planned nonutility electric generating facilities in the United States with a total generator nameplate capacity of 1 megawatt or more.

An analysis of the Form EIA-867 universe indicates that the survey's capacity under coverage varies between 3

17 Even if stock data are only approximate, conventional energy stocks are normally a small percentage of production.

18 Information in this section is based on the report, "Renewable Energy Frame Review Updated Report: Survey Sampling Frame and Electricity Discrepancy Estimates," by Decision Analysis Corporation of Virginia (Vienna, Virginia, August 1993).

19 Because the MECS is based on the Bureau of the Census' Annual Survey of Manufacturers, EIA does not know the identity of MECS respondents. 
and 10 percent, depending on the fuel source (Table B1.). Capacity and unit coverage are the most difficult for wind, where numerous small units exist. EIA has analyzed the differences between capacities reported for identical renewable units on Form EIA-867 and alternative sources. Capacity discrepancies were found to result from these factors:

- Obsolete information

- Facility versus generator reporting: A non-EIA source may cite capacity figures for an entire facility, not taking into account individual generators that use conventional fuels or a mixture of conventional and renewable fuels

- Capacity definition differences: Form EIA-867 requests respondents to report nameplate electric capacity. However, alternative capacity measures are being reported on non-EIA data sources

- Numerical rounding practices: This has the greatest effect on small units.

In a follow-up study of capacity discrepancies, the EIA867 was over four times more likely to have the correct value than the alternative source, which covered units of all sizes.

\section{Industrial (Nonutility) Generation}

Until this issue of this report, nonutility generation for the current year was based on preliminary estimates of nonutility generation, with final data appearing in the following year's issue. An examination of 1996 data reveals that the preliminary estimate overstated the year-to-year increase in generation by a substantial amount (Table B2). In this report, final 1997 data comes from the Form EIA-867, "Annual Nonutility Power Producer Report," eliminating the source of error associated with preliminary data.

\section{Table B2. Preliminary and Final Nonutility Renewable Generation Data Comparison (Billion Kilowatthours)}

\begin{tabular}{c|c|c}
\hline Source & $\begin{array}{c}1996 \\
\text { Preliminary }\end{array}$ & $\begin{array}{c}1996 \\
\text { Final }\end{array}$ \\
\hline Biomass $\ldots \ldots \ldots$ & 62,107 & 57,937 \\
Geothermal ..... & 11,015 & 10,198 \\
Hydroelectric . . . & 16,712 & 16,555 \\
Wind . . . . . . & 3,507 & 3,400 \\
Solar ......... & 908 & 903 \\
\hline
\end{tabular}

Sources: 1996 Preliminary: Energy Information Administration, Annual Energy Review 1996, DOE/EIA-0384(96) (Washington, DC, July 1997); 1996 Final: Table 4 of this report.

\section{Non-Electric Renewable Energy Consumption}

\section{Overview}

The primary application for renewable energy other than making electricity is creating heat for industrial processes, buildings, or water. Most non-electric

Table B1. Evaluation of EIA's Undercoverage of Nonutility Electricity Data

\begin{tabular}{|c|c|c|c|}
\hline Fuel & $\begin{array}{r}\text { Source } \\
\end{array}$ & Number of Facilities ${ }^{a}$ & $\begin{array}{c}\text { Capacity } \\
\text { (megawatts) }\end{array}$ \\
\hline \multirow{2}{*}{ Biomass ... } & EIA-867 $(\geq 1 \mathrm{MW})$ & 471 & 14,090 \\
\hline & "Electricity Discrepancy Estimates" & 759 & 15,037 \\
\hline \multirow[t]{2}{*}{ Geothermal ..... } & ElA-867 & 48 & 1,551 \\
\hline & "Electricity Discrepancy Estimates" & 57 & 1,590 \\
\hline \multirow[t]{2}{*}{ Wind } & EIA-867 & 82 & 1,803 \\
\hline & "Electricity Discrepancy Estimates" & 739 & 1,992 \\
\hline \multirow[t]{2}{*}{ Solar } & EIA-867 & 11 & 365 \\
\hline & "Electricity Discrepancy Estimates" & 152 & 374 \\
\hline
\end{tabular}

\footnotetext{
${ }^{a}$ Excludes some EIA-867 facilities that could not be matched with facilities contained in non-EIA data sources.

${ }^{b}$ Based upon the 1991 survey year. Excludes some EIA-867 facilities that could not be matched with facilities contained in nonEIA data sources. The 1991 EIA-867 survey did not indicate what nonutility facilities under 5 megawatts are renewable.

c"Renewable Energy Frame Review Updated Report: Survey Sampling Frame and Electricity Discrepancy Estimates," by Decision Analysis Corporation of Virginia, August 2, 1993.

Source: Energy Information Administration, Form EIA-867, "Annual Nonutility Power Producer Report."
} 
consumption data are gathered on two EIA consumption surveys: the Manufacturing Energy Consumption Survey (MECS), and the Residential Energy Consumption Survey (RECS). MECS is based on the U.S. Bureau of the Census' Census of Manufacturing. As far as renewable energy is concerned, MECS provides consumption estimates of total industrial energy and various categories of biomass, including wood. RECS is based on an area probability sample of households selected by EIA. For renewable energy, it provides estimates of residential wood energy consumption.

There are three other non-electric applications for renewable energy: solar heating, alcohol transportation fuels, and geothermal energy. Solar energy for nonelectric applications is derived from the EIA Solar Collector Manufacturing Survey, Form EIA-63A/B (formerly CE-63A/B). The survey does not collect energy "consumption" data, but rather production statistics on various types of solar and photovoltaic energy units. EIA applies additional assumptions regarding their application to estimate the amount of heat energy derived from installed solar/PV panels. Alcohol fuel consumption information is provided by the Form EIA-819M, "Monthly Oxygenate Telephone Report." Geothermal non-electric energy information is taken from data provided by the Oregon Institute of Technology, Geo-Heat Center.

\section{Biomass}

Wood is the principal component of biomass energy. Information on non-electric wood energy consumption is derived from the MECS and RECS surveys.

Although some questions about MECS coverage have been raised, no formal analysis of current data exists to support this concern. According to 1983 U.S. Forest Service statistics on wood harvested for fuelwood, the Pulp and Paper Industry subgroup of the Forest Products Industry group consumed only 42 percent of total sector wood energy, not including black liquor (a byproduct fuel). MECS surveys the smaller-populated Pulp and Paper Industry intensively but only randomly samples the larger-populated remainder of the Forest Products Industry. For a variety of reasons, it is difficult to trace wood energy supply to wood consumed for energy. RECS covers wood consumption only for the primary residence of those surveyed; thus, wood consumption by second homes is omitted. This causes residential wood energy consumption to be understated by about 5 percent, if not adjusted. Beginning this year, EIA is adjusting RECS wood consumption estimates for second home use.
Cross-checks of Form EIA-819M information on alcohol fuels with data from the Bureau of Alcohol, Tobacco, and Firearms and the U.S. Department of Transportation have not revealed any major deficiencies in the Form EIA-819M data.

\section{Geothermal}

EIA does not collect data on non-electric applications of geothermal energy such as crop drying and groundwater heat pumps. A study prepared for the U.S. Department of Energy by the Oregon Institute of Technology, Geo-Heat Center, indicates that non-electric uses of geothermal energy amounted to nearly 16.2 trillion Btu in 1997 (Table B3). Sixty-four percent of this energy was provided by geothermal heat pumps.

\begin{tabular}{|c|c|c|c|}
\hline & Direct Use & $\begin{array}{l}\text { Heat } \\
\text { Pumps }\end{array}$ & Total \\
\hline $1990 \ldots$ & 0.0048 & 0.0054 & 0.0102 \\
\hline $1991 \ldots$ & 0.0050 & 0.0060 & 0.0110 \\
\hline $1992 \ldots$ & 0.0051 & 0.0067 & 0.0118 \\
\hline $1993 \ldots$ & 0.0053 & 0.0072 & 0.0125 \\
\hline $1994 \ldots$ & 0.0054 & 0.0078 & 0.0132 \\
\hline $1995 \ldots$ & 0.0056 & 0.0085 & 0.0141 \\
\hline $1996 \ldots$ & 0.0057 & 0.0095 & 0.0152 \\
\hline $1997 \ldots$ & 0.0059 & 0.0103 & 0.0162 \\
\hline
\end{tabular}

Source: John Lund, Oregon Institute of Technology, GeoHeat Center (Klamath Falls, Oregon, March 1998), unpublished data.

\section{Wind, Solar, and Photovoltaics}

EIA does not collect information on direct energy uses of wind (e.g., water-pumping). No comprehensive source of such information is known.

The data collected on Forms EIA-63A and EIA-63B are subject to various limitations: (1) coverage (the list of respondents may not be complete or, on the other hand, there may be double counting); (2) nonresponse (some of those surveyed may not respond, or they may not provide all the information requested); and (3) adjustments (errors may be made in estimating values for missing data).

EIA collects solar data only on terrestrial systems; it does not collect data on satellite and military 
applications. The total value of U.S. photovoltaic shipments in 1997 according to the Forms EIA-63A and EIA-63B was $\$ 175$ million. Based on anecdotal information for 1998, shipments ranging from about $\$ 150$ million to $\$ 160$ million went for satellite applications. Military applications cannot be estimated due to classified information and budgetary accounting. These figures do not include possible inventories held by distributors, retailers, and installers.

The universe of solar / PV survey respondents is a census of those U.S.-based companies involved in manufacturing and/or importing solar collectors and photovoltaic cells and modules. Care has been taken to establish the survey frames accurately. The frames of potential respondents are compiled from previous surveys and from information in the public domain. However, because the solar collector and photovoltaic cell and module industries are subject to sporadic entry and exit of manufacturers and importers, the frame may exclude some small companies that have recently entered or reentered the industry. From 1993 through 1997, EIA received reports from all known potential respondents.

\section{Geothermal Heat Pump Manufacturing Activity}

In 1997, the EIA began collecting information on geothermal heat pumps using its new survey the Form EIA-902, "Annual Geothermal Heat Pump Manufacturers Survey." The principal data collected are the number and type of heat pumps and their capacity ratings.

The data collected on Form EIA-902 are subject to various sources of error. These sources are: (1) coverage (the list of respondents may not be complete or, on the other hand, there may be double counting); (2) nonresponse (all that are surveyed may not respond or may not provide all information requested); (3) respondents (respondents may commit errors in reporting the data); (4) processing (the data collection agency may omit or incorrectly transcribe a submission); (5) concept (the data collection elements may not measure the items they were intended to measure); and (6) estimation (errors may be made in estimating values for missing data). Because the survey is a census survey, the estimates shown in this report are not subject to sampling error. Although it is not possible to present estimates of nonsampling error, precautionary steps were taken at each stage of the survey design to minimize the possible occurrence of these errors.

Follow-up contacts with EIA-902 respondents suggest that the most important data quality issue is whether manufacturers are reporting ARI-320 units accurately, because these units can be used in multiple applications. ARI-320 units may be connected either to a "boiler / cooling tower" configuration or ground / ground water. Ground / ground water connections are geothermal applications, while boiler / cooling tower configurations are traditional water-to-water heat exchange uses. Some respondents apparently interpreted any water-to-water connection as geothermal and therefore reported all ARI-320 shipments as being units used in geothermal applications. The potential error is very large, possibly exceeding 50 percent of the ARI-320 estimate. Also, most manufacturers do not have records indicating the application type for individual ARI-320 units shipped. Therefore, manufacturer data reported on the EIA-902 for ARI-320 units are estimates and not counts.

Another data quality issue involves the distinction between ARI-325 and ARI-330 units. Many ARI-325 units are dual-rated to qualify as ARI-330 units, also. Which rating is appropriate depends upon the installed application, another factor not known when the manufacturer ships the unit. Therefore, while the sum of ARI-325 and ARI-330 units may be regarded as an accurate total, manufacturers estimate the number in each category based upon heuristic information.

EIA will be addressing these data quality issues in two steps. For the upcoming survey being sent out in 1999, the EIA-902 instructions and form will be clarified to emphasize the type of ARI-320 applications manufacturers should report as geothermal. Subsequently, EIA will propose modifications to the year 2000 survey to address the above issues. 


\section{Appendix C}

\section{Geothermal Heat Pump Survey Methodology}

The Energy Information Administration (EIA) uses the Form EIA-902, "Annual Geothermal Heat Pump Manufacturers Survey," to collect annual information about the U.S. geothermal heat pump industry. Using this survey, the EIA obtains data from all U.S.-based geothermal heat pump manufacturers. Respondents to the survey are required to report data, by average rated capacity on: (1) shipments by calendar year; (2) shipments by destination; (3) shipments by type of customer; and (4) shipments by economic sector. The survey form and instructions are contained herein.

\section{Survey Universe and Frame}

The universe of the EIA-902 respondents is a census of U.S.-based companies involved in manufacturing geothermal heat pumps. Sources of potential respondents are compiled from previous surveys, professional and trade associations, and information in the public domain. However, because the geothermal heat pump industry is subject to sporadic entry and exit of manufacturers, the frame could exclude some small companies that recently entered (or re-entered) the industry.

\section{Survey Procedures}

The survey forms were sent out via first class mail to ensure their receipt only by the proper respondent organization. If the U.S. Postal Service was unable to deliver a survey form, the corrected address was obtained where possible. All known companies manufacturing geothermal heat pumps were contacted during this survey.

Approximately half of the respondents replied to the form within the specified initial deadlines. Those that did not were mailed another form specifying a new deadline. Those that had not responded by the second deadline were telephoned to encourage submission of the forms, and those calls resulted in the submission of the remaining forms.

\section{Data Editing, Analyzing, and Processing}

Responses to the surveys were first edited manually to verify the accuracy of the reporting and to ensure reliability of the data. Wherever manual editing procedures indicated discrepancies or omissions, telephone calls were made to confirm or clarify the data. Data from manually edited forms were then entered into the database and edited a second time via an automated procedure. After the second edit, a copy of each entry was reviewed by an analyst familiar with the survey, the geothermal heat pump industry, and its companies.

\section{Response Rates}

The response rate for the EIA-902 survey was 100 percent. The status of the companies that were mailed the Form EIA-902 is:

- Active Companies: Eighteen (18) companies are known to have shipped geothermal heat pumps during 1997.

- Out of Business: Twenty (20) companies reported being out of the geothermal heat pump industry during 1997.

\section{Nondisclosure of Data}

To protect the confidentiality of individual respondents' data, a policy was implemented to ensure that the reporting of survey data in this publication would not associate those data with a particular company. This is in compliance with EIA Standard No. 88-05-06 "Nondisclosure of Company Identifiable Data in Aggregate Cells." In tables where the nonzero value of a cell is composed of data from fewer than three companies, or if a single company dominates a table-cell value so that the publication of the value would lead to identification of a company's data, the EIA classifies the cell value as "sensitive" and the cell value is withheld ("W") from publication. Within a table having a sensitive cell value, 
selected values in other cells of the table are also withheld, as necessary, so that the sensitive cell value cannot be computed using the values in published cells.

A sensitive table-cell value can be reported, if permission is first obtained from each company (whose data contribute to the sensitivity) to publish the value. This is the only exception to the application of EIA Standard No. 88-05-06 in this report.

\section{Survey Accuracy}

A discussion of potential limitations on the accuracy of the data collected on the Form EIA-902 is contained in Appendix B. 
U.S. Department of Energy Energy Information Administration FORM EIA-902 (1997)
FORM EIA-902

ANNUAL GEOTHERMAL HEAT PUMP MANUFACTURERS SURVEY 1997
Form Approved OMB No. 1901-0303,

Expires 8/31/2000

\section{GENERAL INFORMATION AND INSTRUCTIONS}

\section{PURPOSE}

Form EIA-902 is used to collect data about the manufacture and distribution of geothermal heat pumps and the status of the industry. The information collected will be used by public and private analysts interested in geothermal heat pumps and related energy issues.

\section{WHO MUST SUBMIT}

This report is mandatory and is being required pursuant to the authority granted to the Department of Energy (DOE) by the Federal Energy Information Administration Act of 1974 (Public Law 93-275). Form EIA-902 is to be submitted by all companies within the 50 States, District of Columbia, Puerto Rico, the Virgin Islands, Guam, and the other U.S. territories and possessions which manufactured and shipped any geothermal heat pumps during the period 1994-1996. The form requests information on any geothermal heat pumps shipped in calendar years 1994, 1995, and 1996, and detailed information about shipments made in 1996.

\section{WHERE TO SUBMIT COMPLETED FORMS}

Return the completed Form EIA-902 to:

\author{
U.S. Department of Energy (EI-522) \\ Energy Information Administration, BG-094 \\ 1000 Independence Ave., SW \\ Washington, D.C. 20277-7091
}

Completed forms may also be faxed to Peter Holihan, the Form EIA-902 Manager, at (202) 426-1308. Requests for further information and/or additional forms may be mailed to the above address, telephoned to $\mathrm{Mr}$. Holihan at (202) 426-1147, or sent by E-mail to JHolihan@eia.doe.gov

\section{WHEN TO SUBMIT}

Completed EIA-902 forms are due by October 20, 1997.

\section{SANCTIONS}

The timely submission of Form EIA-902 by those required to report is mandatory under Section 13(b) of the Federal Energy Administration Act of 1974 (FEAA) (Public Law 93-275), as amended. Failure to respond may result in a civil penalty of not more than $\$ 2,500$ for each violation, or a fine of not more than $\$ 5,000$ lor each willful violation. The government may bring a civil action to prohibit reporting violations which may result in a temporary restraining order or a preliminary or permanent injunction without bond. In such civil action, the court may also issue mandatory injunctions commanding any person to comply with these reporting requirements.

\section{PROVISIONS REGARDING CONFIDENTIALITYOFINFORMATION}

The Office of Legal Counsel of the Department of Justice concluded on March 20, 1991, that the Federal Energy Administration Act requires the Energy Information Administration to provide company-specific data to the Department of Justice, or to any other Federal agency when requested for official use, which may include enforcement of Federal law. The information contained on this form may also be made available, upon request, to another component of the Department of Energy (DOE), to any Committee of Congress, the General Accounting Office, or other Congressional agencies authorized by law to receive such information. A court of competent jurisdiction may obtain this information in response to an order.

The information contained on this form will be kept confidential and not disclosed to the public to the extent that it satisfies the criteria for exemption under the Freedom of Information Act (FOIA), 5 U.S.C. \$552, the DOE regulations, 10 C.F.R. $\$ 1004.11$, implementing the FOIA, and the Trade Secrets Act, 18 U.S.C. $\S 1905$. 
Upon receipt of a request for this information under the FOIA, the DOE shall make a final determination whether the information is exempt from disclosure in accordance with the procedures and criteria provided in the regulations. To assist in this determination, respondents should demonstrate to the DOE that, for example, their information contains trade secrets or commercial or financial information whose release would be likely to cause substantial harm to their company's competitive position. A letter accompanying the submission that explains (on an element-by-element basis) the reasons why the information would likely cause the respondent substantial competitive harm if released to the public would aid in this determination. A new justification does not need to be provided each time information is submitted on the form, if the company has previously submitted a justification for that information and the justification has not changed.

\section{SPECIFIC INSTRUCTIONS}

1.01 Make corrections to the company name or address in the spaces (a-e) provided

2.0 Enter the number of geothermal heat pumps and the total rated capacity in tons of those pumps for each heat pump type listed that was manufactured and shipped in each of the years 1994, 1995, and 1996. The totals should be the sums of the various heat pump types and their capacities for each report year.

3.0 Enter the number of geothermal heat pumps by type shipped in 1996 to each destination listed. Destinations include exported as well as the 50 States, the District of Columbia, Puerto Rico, and the U. S. Virgin Islands. Include shipments within the State of manufacture.

4.0 Enter the number of geothermal heat pumps shipped to each type of customer in 1996. If a customer could be included in more than one of the customer categories listed, include the number of pumps shipped to that customer in the first appropriate category in the list. For example, if a customer is both an exporter and a wholesale distributor, shipments to that customer would be classified as shipments to an "exporter." Another example is a cuslomer that is both a retail distributor and an installer. Shipments to that customer would be repo,ted under the "retail distributor" category because that category appears in the list before the "installer" category.
5.0 For each economic sector enter the average rated capacity (size in tons) of geothermal heat pumps by type shipped in 1996. The economic sectors are defined below. (Detailed descriptions are in the Definitions section of the instructions):

Residential-Geothermal heat pump applications related to any building used for residential occupancy that has a system for heating or cooling, or both. This includes single-family homes, multifamily dwellings, and mobile. Institutional housing, such as school dormitories, hospitals, and military barracks should be included in the "Commercial" category.

Commercial-Geothermal heat pump applications for use in businesses where services (rather than products) are provided, such as wholesale and retail trade or health and educational services. Institutional housing such as school dormitories, hospitals, and military barracks are included in the commercial sector. Federal, State, and local government should not be included in commercial, but should be reported in the "Government" category.

Industriat-Geothermal heat pump applications for use in business where products (rather than services) are provided, such as the manufacture and processing of goods and basic materials. Also included are mining, construction, agriculture, fisheries, and forestry. Electric utilities should not be included in the industrial sector, but should be reported in the "Electric Utility" category. 
Item

5.0 (continued)

Government -Geothermal heat pump applications for use with local, State, or Federal government buildings.

Electric utility -Geothermal heat pump applications used at any electric utility. Nonutility power producers should not be included in the electric utility sector.

Other-Shipments of heat pumps to customers that can not be included in one of the economic sectors listed above. Please include a briet description of the customer type. 
1. ARI certified: certification by the Air-Conditioning and Refrigeration Institute (ARI) that a pump has been tested using procedures stipulated in ARI standards and that it meets the manufacturer's certified published performance rating.

ARI Standards 320,325 , and 330 refer to a rating system for testing performance of a water source heat pump when installed under three different conditions. For this reason, a single pump could be certified under all three ratings, and could potentially be installed under different circumstances.

Geothermal heat pumps refer to systems where the unit uses the earth or natural body of water as a heat sink. There are typically three types of geothermal systems:

1) A water source heat pump rated under standard ARI-320 is typically installed in a commercial application where several heat pumps are installed in series, with a central chiller or boiler supplying the heating or cooling of the fluid.

2) A ground water source system is a standard ARI-325 installation, and is an open-loop system that uses a natural body of water for the exchange of heat. An open-loop heat pump system is a heat pump system that directly utilizes water from a well or water body, pumps it through a pipe for use as a heat exchanger and returns it back to the environment.

3A) A ground source system is a standard ARI-330 installation, and is a closedloop system that uses water or a water/glycol solution to exchange heat. The system employs extensive tubing which is buried fairly deep the ground. A closed-loop heat pump system is a geothermal heat pump system that uses water/anti-freeze in a buried pipe loop as a heat exchanger. The water/anti-freeze in the loop never leaves the system. Loop piping can be installed vertically or horizontally in the earth, a lake, a channel or the ocean.

3B) A direct expansion system is a geothermal heat pump system that uses refrigrerant in a buried pipe loop as a heat exchanger. The refrigerant in the loop never leaves the system. A direct expansion system is also ground source system with a closed-loop which uses refrigerant throughout the system rather than a water/glycol solution to exchange heat.

2. Commercial sector: The commercial sector, as defined economically, consists of all business facilities and organizations that are engaged in other than those classified as industrial (manufacturing, agriculture, forestry, fisheries, mining, and construction), government, or electric utilities. Commercial establishments include hotels, motels, restaurants, wholesale businesses, retail stores, laundries, and other enterprises; religious and nonprofit organizations; transportation facilities such as bus stations, airports, and train stations; health, social, and educational institutions. Institutional housing, such as school dormitories, hospitals, and military barracks are included in the commercial sector. Federal, State, and local governments are not included in the commercial sector for this survey, but should be reported in the government sector.

3. Electric utility sector: The electric utility sector includes a corporation, person, agency, authority, or other legal entity or instrumentality that owns, and/or operates facilities for the generation, transmission, distribution, or sale of electric energy. Nonutility electric power producers are not included in the electric utility sector and should be included in the industrial sector.

4. Geothermal heat pump; Also referred to as ground-source, earth-coupled, or ground-water heat pumps. A pump which uses the earth as a heat sink during warm weather and as a heat source during colder weather. A pump is rated to ARI standards but may not be certified by ARI.

5. Government sector: The government sector includes all local, State, and Federal government buildings. This includes military barracks.

6. Heat sink: A substance into which heat is injected or is absorbed. Substances can be gas, liquid or solid like air, water and earth.

7. Heat source: A substance from which heat is received or radiates. Substances can be a gas, liquid or solid like air, water and earth. 
8. Industrial sector: The industrial sector comprises manufacturing industries, which make up the largest part of the sector, along with mining, construction, agriculture, fisheries, and forestry. Establishments in this sector range from steel mills, to small farms, to companies assembling electronic components. Electric utilities should not be included in the industrial sector but should be reported in the electric utility sector.
9. Residential sector: The residential sector consists of all private residences, whether occupied or vacant, owned or rented, including singlefamily homes, multifamily housing units, and mobile homes. Secondary homes, such as summer homes, are also included. Institutional housing, such as school dormitories, hospitals, and military barracks are included in the commercial sector.

10. Ton: A measure of the amount of Btu's (British thermal units) needed to melt one ton of ice in a 24-hour period. One ton equals 12,000 Btu's/hour available to heat and/or cool space. 
Energy Information Administration

U.S. Department of Energy
Form Approved

OMB No. 1901-0303

Expiration Date: $8 / 31 / 2000$

\section{ANNUAL GEOTHERMAL HEA.T PUMP MANUFACTURERS SURVEY FORM EIA-902}

This report is authorized under Federal Energy Administration Act of 1974 (Public Law 93-275). Your response is mandatory and confidential. For the provisions regarding the confidentiality of information submitted on this form, see Part VI of the instructions. Respondents are not required to file or reply to any Federal collection of information unless it has a valid OMB control number. Public reporting burden for this collection of information is estimated to average 4 hours per response including the time for reviewing instructions, searching existing data sources, gathering and maintaining the data needed, and completing and reviewing the collection of information. Send comments regarding this burden estimate or any other aspect of this collection of information, including suggestions for reducing this burden to the Energy Information Administration, Statistics and Methods Group, EI-70, 1000 Independence Ave., S.W., Washington, D.C. 20585-0670, and the Office of Information and Regulatory Affairs, Office of Management and Budget, Washington, D.C. 20503.

\section{The report period for Question 2 is calendar years 1994-1996. \\ Questions 3 - 5 are for calendar year 1996 shipments only.}

For instructions and definitions, please refer to the General Information and Instructions included with this form.

If you have any additional questions, please call Peter Holihan, the Survey Manager, at (202) 426-1147.

1.0 RESPONDENT INFORMATION

ADDRESS LABEL HERE
Use (a) through (e) below only if the label is incorrect.

(a) Company Name:

(b) Street Address:

(c) City :

(d) State:

(e) Zip:

2.0 SHIPMENTS IN CALENDAR YEARS 1994-1996 - Please enter the total number of units and the total rated capacity for each type of geothermal heat pump unit shipped for the years 1994, 1995, and 1996.

\begin{tabular}{|c|c|c|c|c|c|c|c|}
\hline $19 \sqrt{9}$ & 6 & & & & & & \\
\hline Code & $\begin{array}{l}\text { Type of Geothermal } \\
\text { Heat Pump (GHP) }\end{array}$ & $\begin{array}{c}\text { Number } \\
\text { of GHPs } \\
\text { (1) }\end{array}$ & $\begin{array}{l}\text { Total Rated } \\
\text { Capacity } \\
\text { (in tons) } \\
\text { (2) }\end{array}$ & $\begin{array}{c}\text { Number } \\
\text { of GHPs } \\
\text { (3) }\end{array}$ & $\begin{array}{l}\text { Total Rated } \\
\text { Capacity } \\
\text { (in tons) } \\
\text { (4) }\end{array}$ & $\begin{array}{c}\text { Number } \\
\text { of GHPs } \\
\text { (5) }\end{array}$ & $\begin{array}{l}\text { Total Rated } \\
\text { Capacity } \\
\text { (in tons) } \\
\text { (6) }\end{array}$ \\
\hline 1 & ARI-320 for GHP only & & & & & & \\
\hline 2 & ARI-325 & & & & & & \\
\hline 3 & ARI-330 & & & & & & \\
\hline 4 & Other Non-ARI Rated & & & & & & \\
\hline 5 & TOTALS & & & & & & \\
\hline
\end{tabular}


3.0 SHIPMENTS IN 1996 BY DESTINATION-Enter the number of geothermal heat pumps your company shipped in 1996 to the destinations (i.e., exported, by State, the District of Columbia, Puerto Rico, and the Virgin Islands) listed below. Include in the shipments geothermal heat pumps shipped within the state of manufacture. If any geothermal heat pumps were exported, please indicate the number exported under Code 00.

\begin{tabular}{|c|c|c|c|c|c|}
\hline & 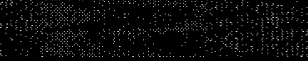 & & R OF GEC & IAL HEA & S SHIPPED IN 1996 \\
\hline Code & Destination & $\begin{array}{l}\text { ARI-320 } \\
\text { (1) }\end{array}$ & $\begin{array}{l}\text { ARI-325 } \\
\text { (2) }\end{array}$ & $\begin{array}{l}\text { ARI-330 } \\
\text { (3) }\end{array}$ & $\begin{array}{l}\text { Other Non-ARI Rated GHPs } \\
\text { (4) }\end{array}$ \\
\hline 00 & Exported & & & & \\
\hline 01 & Alabama & & & & \\
\hline 02 & Alaska & & & & \\
\hline 03 & Arizona & & & & \\
\hline 04 & Arkansas & & & & \\
\hline 05 & California & & & & \\
\hline 06 & Colorado & & & & \\
\hline 07 & Connecticut & & & & \\
\hline 08 & Delaware & & & & \\
\hline 09 & District of Columbia & & & & \\
\hline 10 & Florida & & & & \\
\hline 11 & Georgia & & & & \\
\hline 12 & Hawaii & & & & \\
\hline 13 & Idaho & & & & \\
\hline 14 & Illinois & & & & \\
\hline 15 & Indiana & & & & \\
\hline 16 & Iowa & & & & \\
\hline 17 & Kansas & & & & \\
\hline 18 & Kentucky & & & & \\
\hline 19 & Louisiana & & & & \\
\hline 20 & Maine & & & & \\
\hline 21 & Maryland & & & & \\
\hline 22 & Massachusetts & & & & \\
\hline 23 & Michigan & & & & \\
\hline 24 & Minnesota & & & & \\
\hline 25 & Mississippi & & & & \\
\hline 26 & Missouri & & & & \\
\hline 27 & Montana & & & & \\
\hline 28 & Nebraska & & & & \\
\hline 29 & Nevada & & & & \\
\hline 30 & New Hampshire & & & & \\
\hline
\end{tabular}




\subsection{SHIPMENTS IN 1996 BY DESTINATION (continued)}

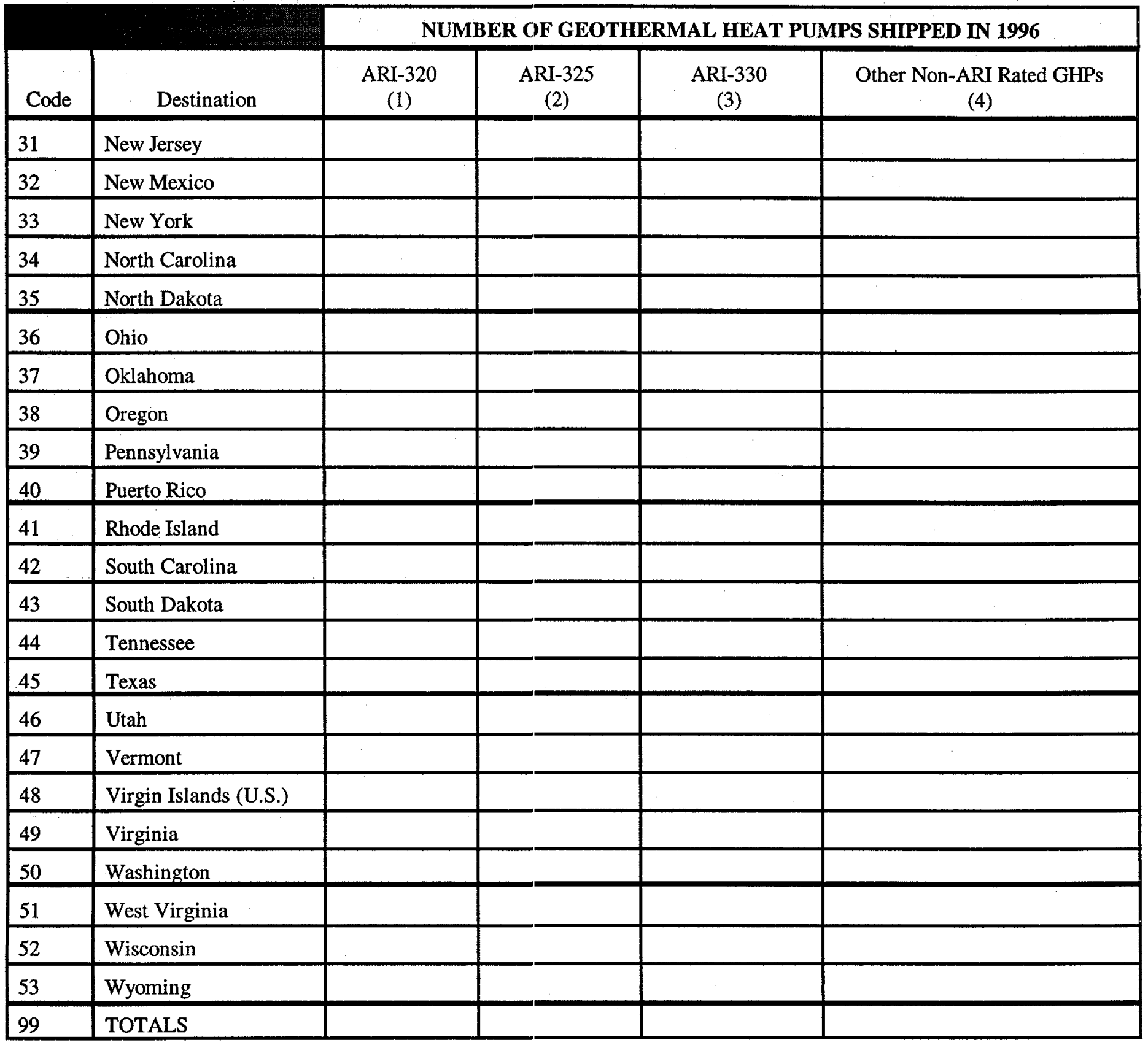


4.0 1996 SHIPMENTS BY TYPE OF CUSTOMER - Enter the number of geothermal heat pumps shipped in 1996 by customer type. If a customer could be included in more than one category (e.g., a retail distributor who is also an installer), report the units shipped to that customer in the first appropriate category listed (i.e., retail distributor for the example listed).

\begin{tabular}{|l|l|c|c|c|c|}
\hline \multicolumn{1}{|c|}{ Customer Type } & $\begin{array}{c}\text { ARI-320 } \\
(1)\end{array}$ & $\begin{array}{c}\text { ARI-325 } \\
(2)\end{array}$ & $\begin{array}{c}\text { ARI-330 } \\
(3)\end{array}$ & $\begin{array}{c}\text { Other Non-ARI Rated GHPs } \\
(4)\end{array}$ \\
\hline 1 & Exporter & & & & \\
\hline 2 & Wholesale Distributor & & & & \\
\hline 3 & Retail Distributor & & & & \\
\hline 4 & Installer & & & & \\
\hline 5 & End-User & & & & \\
\hline 6 & Others (describe) & & & & \\
\hline 7 & TOTALS & & & & \\
\hline
\end{tabular}

5.0 1996 SHIPMENTS BY ECONOMIC SECTOR - Enter the average rated capacity (i.e., size in tons) of each type of geothermal heat pump shipped in 1996 to each economic sector.

\begin{tabular}{|c|c|c|c|c|c|}
\hline & 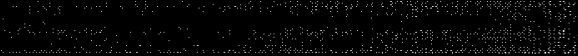 & \multicolumn{4}{|c|}{ AVERAGE RATED CAPACITY (size in tons) } \\
\hline Code & Economic Sector & $\begin{array}{l}\text { ARI-320 } \\
\text { (1) }\end{array}$ & $\begin{array}{l}\text { ARI-325 } \\
\text { (2) }\end{array}$ & $\begin{array}{l}\text { ARI-330 } \\
\text { (3) }\end{array}$ & $\begin{array}{c}\text { Other Non-ARI Rated GHPs } \\
\text { (4) }\end{array}$ \\
\hline 1 & Residential & & & & \\
\hline 2 & Commercial (excluding government) & & & & \\
\hline 3 & Industrial (excluding electric utilities) & & & & \\
\hline 4 & Government (local, State, and Federal) & & & & \\
\hline 5 & Electric utility & & & & \\
\hline 6 & Other (describe) & & & & \\
\hline
\end{tabular}

\subsection{ADDITIONAL INFORMATION}

6.1 Enter any additional comments or remarks here:

6.2 Do you want the name and address of your company to appear in the Energy Information Administration report publishing data collected in this survey? Yes__ No

6.3 Do you want to receive a copy of the report publishing the survey data?

Yes No

\subsection{CONTACT PERSON}

7.1 Name:

7.3 Signature: 7.2 Title: 7.4 Date: 7.5 Phone Number:

Completed forms should be mailed to: U.S. Department of Energy (EI-522), Energy Information Administration, BG-094, 1000 Independence Ave. SW, Washington, D.C. 20277 7091

Completed forms may also be faxed to: ATTN: Peter Holihan at 202-426-1308. 



\section{Appendix D \\ Selected List of Internet Addresses: Renewable Energy Information by Resource}

The list of addresses that follow are current as of Summer 1998. This list is abbreviated due to the great increase in internet sites as well as the growing presence of links to associated web sites over the past few years. Therefore, this list should provide at least a useful start in a search for renewable energy information.

\section{General: Renewables}

Department of Energy (DOE), Energy Efficiency and Renewable Energy Homepage http://eren.doe.gov

For information on DOE Renewable Energy Regional Offices

http://www.eren.doe.gov/rso.html

Energy Information Administration Homepage

http://www.eia.doe.gov

North Carolina Solar Center, Renewable Energy State Incentives Database (co-sponsored by DOE)

http://www.ncsc.ncsu.edu

Center for Renewable Energy and Sustainable Technology

http://www.crest.org./renewables/index.html

International Energy Agency

IEA CADDET International Information on Renewable Energy

http://www.caddet.co.uk/re/

National Renewable Energy Laboratory

NREL Publication Index

http://www.nrel.gov/cgi-bin/pubspage.cgi

National Association of Regulatory Utility Commissioners (NARUC) Homepage

http://www.naruc.org/

California Energy Commission

http://www.energy.ca.gov/index.html

\section{Biomass: Wood}

Regional Wood Energy Development Programme in Asia

http://www.rwedp.org/

WSU Energy Program Library Title List: Wood Fuels

http://www.energy.wsu.edu/ep/library/catalog/eng/slinks/s002476.htm 
Supply of Short Rotation Woody Crop Biomass to the Watts Bar Power Facility This is a brief description of studies that exemplify the methods and approaches that have been developed:

http://www.esd.ornl.gov/iab/iab5-7.htm

and for standing woody biomass (TREEDYN3*):

http://www.gsf.de/UFIS/ufis/modell60/grs957.html

Chemical Nature of Biomass from Semi-Arid Forest Tree: Species S5.01-02 Natural Variations in Wood Quality / P5.01-00 Properties and Utilization of Tropical Woods Theme: ...

http://www.metla.fi/conf/iufro95abs/d5pap22.htm

PCSD Agriculture: Biomass PCSD BRIEFING BOOKSustainable Agriculture BIOMASS ENERGY INITIATIVESPROJECT HISTORY

http://bertha.chattanooga.net/sustain/pcsd_briefing_book/agriculture_biomass.html

http://www.gsf.de/UFIS/ufis/schlag_groessen/schlagwort419.html

\section{Biomass: Biofuels}

Biofuels (Federal Government) Resources on the Internet

http://www.nal.usda.gov/ttic/biofuels/nonusda.htm

BioPower Information Network

http://www.eren.doe.gov/biopower/

American Bioenergy Association

http://www.biomass.org/

Bioenergy Information Network Database Annex Search the ORNL Bioenergy Feedstock Development Program Bibliography

http://dsimd.dsrd.ornl.gov/htmldocs/biofuels/biofuels.htp

Energy Information on Internet: BIOFUELS INFORMATION NETWORK ECN_logo Energie Informatie via Internet BIOFUELS INFORMATION NETWORK Title Organization: Biofuels System ...

http://blister.ecn.nl/eii/homepgnl/eii_013.html

Renewable Energy: Biomass and Biofuels Renewable Energy: Biomass and Biofuels

http://lacebark.ntu.edu.au/j_mitroy/sid101/energyfacts/re-bioms.html

Atmospheric Science Curriculum Bookmarks Alternative Fuels Biofuels Information

http://krusty.eecs.umich.edu/people/jreed/weather/ravenbkms.html

Alternative Fuels Data Center

http://www.afdc.doe.gov

Sustainable Energy Energy Agricultural Energy Agricultural Energy Assistance Program, California ALTERNATIVE ENERGY California Energy Commission: Alternative/Renewable Technologies EPA.

http://www.netins.net/showcase/s_energy/energy.htm

National Renewable Energy Laboratories- Biofuels Infcrmation Center; The Biofuels Information Center, managed by the National Renewable Energy Laboratory

http://www.biofuels.nrel.gov/

Short-Rotation Woody Crops (SRWC) Operations Working Group

http://www.esd.ornl.gov/bfdp/srwcwgrp/menu.html 


\section{Municipal Solid Waste}

Characterizations of Municipal Solid Waste in the United States 1995 Update

http://rredc.nrel.gov/biomass/epa/msw95/msw95_index.html

ENVIRONMENTAL STUDIES 17. TOXIC AND SOLID WASTE Most waste produced by preindustrial societies is biodegradable. In industrial societies, much waste is nondegradable ...

http://www.fcn.org/fcn/ecosystem/wast_po.html

The Solid Waste Association of North America

http://www.swana.org/

Municipal Solid Waste Factbook.

http://www.epa.gov/epaoswer/non-hw/muncpl/factbook.htm

Guide to the Preparation of Regional Solid Waste Management Plans by Regional Districts (Part I), British Columbia, Canada

http://www.env.gov.bc.ca/epd/cpr/guidelns/gprswmp1.html

\section{Waste-to-Energy}

Waste-to-Energy in the United States: A Social and Economic Assessment http://www.esd.ornl.gov/iab/iab8-6.htm

Integrated Waste Services Association

http://www.wte.org/index.html

European Energy-from-Waste Coalition

http://www.eewc.org/19.htm

U.K. World Resource Foundation Homepage: sustainable waste management

http://www.wrfound.org.uk/

\section{Geothermal}

GeoLinks

http://www.inter-pc.com/user/josh/es/project/geolinks.html

Geothermal Heat Pumps

http://www.apogee.net/res/rehpgov.htm

Geothermal Products Inc. - Energy Star Programs

http://www.geoproducts.com/estar.html

Geothermal Heat Pump Links

http://www.ilec.org/heatlink.html

Geothermal Technologies Program - Other Resources

http://www.eren.doe.gov/geothermal/resource.html

Geothermal Technologies Program - Publications

http://www.eren.doe.gov/geothermal/public.html 
International Geothermal Association - US DOE Sites

http://www.demon.co.uk/geosci/wrusadoe.html

US DOE/Geothermal Energy Technical Site

http://geothermal.id.doe.gov

Geo-Heat Center, Oregon Institute of Technology, Geothermal Information and Technology Transfer

http://www.oit.osshe.edu/ geoheat/

International Geothermal Association

http://www.demon.co.uk/geosci/igahome.html

IEA: International Energy Agency

http://www.iea.org/stats/defs/sources/geo.htm

U.S. Geothermal Direct Use Projects and Resource Areas

http://www.oit.osshe.edu/ geoheat/dusys.htm

Geothermal Theory: Introduction

Summary: How Geothermal Systems Form. Geothermal Occurances Today.

http://www.crest.org/renewables/re-kiosk/geothermal/theory/index.shtml

Geothermal Energy in California

http://www.energy.ca.gov/development/geothermal/index.html

Geothermal Workshop

Summary: The New Zealand Geothermal Workshop is a three-day conference held annually in early November. The Workshop provides an international forum where engineers and earth scientists discuss aspects of geothermal development.

http://www.auckland.ac.nz/gei/workshop.htm

Geothermal Links

Summary: GEOTHERMAL LABORATORY GEOTHERIMAL LINKS.

Internation Geothermal Association Nappa Valley/Gieysers/Geothermal Area Sites/Geyser Resources/ Coso's Geothermal Field/Water Resources of California/Geothermal Resources/Council World Geothermal Resources / Maps. http://www.geology.smu.edu/ -bonner/geothermlinks.html

Geothermal Theory: Geothermal Use Today

Summary: Geothermal power plants now provide more than 2,500 megawatts of clean electricity to the United States, equivalent to three large nuclear power plants. According to the U.S. Energy Information Administration, geothermal has the potential to provide the United States with 12,000 megawatts of electricity by the year 2010 . http://www.crest.org/renewables/re-kiosk/geothermal/theory/usetoday.shtml

Geothermal Theory, Geothermal Reservoirs: Fractured Rock (2)

Summary: In most high-temperature reservoirs, much of the porosity and permeability exist in natural rock fractures, although they may be artificially induced. In other reservoirs, the space between sand grains in the rock provides ample porosity and permeability.

http://www.crest.org/renewables/re-kiosk/geothermal/theory/fracturedrock2.html

\section{Wind}

Danish Wind Turbine Manufacturers Association

http://www.windpower.dk/core.htm 
Wind Info Resources on the Net

http://www.afm.dtu.dk/wind/bookmark.html

British Wind Energy Association

http://www.bwea.com/

Wind Energy Utilization in the Federal Republic of Germany -

http://www.dewi.de/statistics.html

RICO Wind Energy \& Atmospheric Physics

http://www.risoe.dk/vea-wind/

03/27/95 Talking Points - 25th Annual Conference U. S. Wind Energy Industry Opening Session Monday, March 27, 1995 8:30 a.m. PRESS AVAILABILITY 25th ANNUAL CONFERENCE U.S.

...http://apollo.osti.gov/html/secretry/tp950327.html

American Wind Energy Association. This comprehensive, up-to-date reference includes contact as well as product information. .

http://www.igc.apc.org/awea/aweapage.html

Alternative Energy Institute Homepage:

http://www.wtamu.edu/academic/gradres/aei/

Windpower Monthly

http://www.wpm.co.nz/

U.S. Dept. of Energy, Energy Efficiency and Renewable Energy Network (EREN), Wind Energy Program http://www.eren.doe.gov/RE/wind.html

National Renewable Energy Laboratory's National Wind Technology Center

http://nwtc.nrel.gov/

Wind Power Development

http://www.telosnet.com/wind

\section{Solar Energy}

Solar Energy Industry

http://www.seia.org

International Solar Energy Society

http://wire.ises.org

\section{Solar Thermal}

DOE's Solar Thermal Electric Program

http://www.eren.doe.gov/ste/

ASME Solar Energy Division

http://www.asme.org/divisions/solar/index.html

FREQUENTLY ASKED QUESTIONS - SOLAR POWER

http://www.greenpeace.org.uk//solar//faq2.html 
Solar Energy

http://solstice.crest.org/renewables/re-kiosk/solar/index.shtml

Solar Thermal Case Studies A solar thermal water heating system provides St. Rose Hospital in San Antonio, TX. http://solstice.crest.org/renewables/re-kiosk/solar/solar-thermal/case-studies/commercial.shtml

EREN - Solar Thermal Utilization Energy Efficiency and Renewable Energy Network http://apollo.osti.gov/html/eren/1409.html

EREN - Solar Thermal Power Systems

http://www.doe.gov/html/eren/1407.html

The National Solar Thermal Test Facility (NSTTF) is operated by Sandia National Laboratories for the U.S. Department of Energy. It...

http://www.sandia.gov/Renewable_Energy/solarthermal/nsttf.html

National Solar Thermal Test Facility Questions Frequently Asked by NSTTF Visitors About Solar Energy How do Central Receiver power plants produce electricity from the heat of...

http://www.sandia.gov/Renewable_Energy/solarthermal/question.html

Solar Radiation and Solar Thermal Systems

Date: Saturday, 20-Jul-96 00:46:40 GMT Last-Modified: Wednesday, 11-Oct-95 14:27:55 GMT Content-type: text/html Content-length: 8514 MS 54 Selected Papers on Solar Radiation and ...

http://www.spie.org/web/abstracts/oepress/MS54.html

National Solar Thermal Test Facility Sandia National Laboratories Advantages of Using Molten Salt A variety of fluids was tested to transport the sun's heat, including water, air, ...

http://www.sandia.gov/Renewable_Energy/solarthermal/salt.html

National Solar Thermal Test Facility Sandia National Laboratories Desirable Features of Power Towers for Utilities Because of their practical energy storage, solar power ...

http://www.sandia.gov/Renewable_Energy/solarthermal/feature.html

National Solar Thermal Test Facility Sandia National Laboratories Engine Test Facility, Test Cell 1 and 2 http://www.sandia.gov/Renewable_Energy/solarthermal/engine1.html

The Sun's Joules: Solar Thermal, page 634/937, Solar1 and Solar2

http://www.crest.org/renewables/SJ/solar-thermal/634.html

\section{Solar Photovoltaic}

National Center For Photovoltaics

http://www.nrel.gov/ncpv

\section{PV WEB SITES}

http://www.pvpower.com/pvsites.html

Photovoltaic Energy -- Electricity from the Sunlight

http://www.doe.gov/phv/phvhome.html

Photovoltaic Module - PV Module Businesses in the World

http://www.mtt.com/theSource/renewableEnergy/businesses/byP/pvM/pvM.html

NREL Photovoltaics Program - What is PV?

http://www.nrel.gov/pv/whatispv.html 
Siemens Solar Online

http://www.siemenssolar.com

Power Technology Division PHOTOVOLTAIC GENERATION PHOTOVOLTAIC BRANCH http://powerweb.lerc.nasa.gov/pv/home.html

Advancing Photovoltaic Technology at NREL's Outdoor Test Facility logo

http://www.nrel.gov/lab/pao/otf.html

Million Solar Roofs Program

http://www.millionsolarroofs.org

PV at Electric Utilities

http://www.ttcorp.com/upvg

PV Systems Assistance Center

http://www.sandia.gov/pv

National Center For Photovoltaics

http://www.nrel.gov/ncpv 



\section{Appendix E}

\section{State Energy Agencies}

The following lists the State Energy Office (or equivalent) and the Public Utility Commission (or equivalent) for each State. ${ }^{20}$

\section{Alabama}

State Energy Office

Martha McInnis, Division Chief

Department of Economic and Community

Affairs

Science Technology and Energy Division

P.O. Box 5690

Montgomery, AL 36103-5690

(334) 242-5292

Fax: (334) 242-0552

Public Service Commission

Walter L. Thomas, Jr., Secretary

100 North Union Street

Room 850

P.O. Box 991

Montgomery, AL 36104

(334) 242-5218

Fax: (304) 242-0509

Alaska

State Energy Office

Robert Brean

Alaska Housing Finance Corporation

520 East 34th Avenue

Anchorage, AK 99503

(907) 338-6100

Fax: (907) 338-1747

\section{Alaska Public Utilities Commission}

Robert A. Lohr, Executive Director

1016 West 6th Avenue, Suite 400

Anchorage, AK 99501

(907) 276-6222
Fax: (907) 276-0160

E-Mail: apuc@apuc.ak.net

American Samoa

State Energy Office

Reupena Tagaloa, Director

ASPA/Territorial Energy Office

Samoa Energy House, Tafuna

P.O. Box PPB

Pago Pago, AS 96799

011 (684) 699-1101

Fax: 011 (684) 699-2835

Arizona

State Energy Office

Amanda Ormond, Director

Arizona Department of Commerce

3800 North Central Avenue, Suite 1200

Phoenix, AZ 85012

(602) 280-1402

Fax: (602) 280-1445

\section{Corporation Commission}

James Matthews, Executive Secretary

Arizona Corporation Commission

$1200 \mathrm{~W}$. Washington

Phoenix, AZ 85007-2996

(602) 542-3931

Fax: (602) 542-3977

Arkansas

State Energy Office

Morris Jenkins, Director

Arkansas Energy Office

One State Capitol Mall

Little Rock, AR 72201

(501) 682-7377

Fax: (501) 682-2703

${ }^{20}$ This information was excerpted from, Energy Information Administration, Energy Information Directory, 1998, DOE/EIA-0205(98) (September 1998). 
Public Service Commission

Jerrell Clark, Director

Arkansas Public Service Commission

1000 Center Street

P.O. Box 400

Little Rock, AR 72203-0400

(501) 682-1794

Fax: (501) 682-2572

\section{California}

State Energy Commission

William J. Keese, Chairman

California Energy Commission

1516 9th Street

Sacramento, CA 95814

(916) 654-5000

Fax: (916) 654-4420

California Public Utilities Commission

Wesley M. Franklin, Executive Director

505 Van Ness Avenue, Room 5222

San Francisco, CA 94102

(415) 703-3808

Fax: (415) 703-1758

\section{Colorado}

\section{State Energy Office}

Wade Buchanan, Director

Colorado Office of Energy Conservation

1675 Broadway, Suite 1300

Denver, CO 80202-4613

(303) $620-4292$

Fax: (303) 620-4288

Public Utilities Commission

R. Brent Alderfer, Commissioner

Logan Tower OL2, Logan Street

Denver, CO 80203

(303) 894-2070

Fax: (303) 894-2065

Connecticut

State Energy Office

Allan Johanson

Policy Development and Planning Division

Energy Unit

P.O. Box 341441, MS-52ENR

Hartford, CT 06134-1441

(860) 418-1441

Fax: (860) 418-6297
Department of Public Utility Control

Steven D. Cadwallader, Chief of Research and Policy Analysis

10 Franklin Square

New Britain, CT 06051

(860) $827-2629$

Fax: (860) 827-2613

\section{Delaware}

State Energy Office

Charlie T. Smisson, Jr., Energy Program

Administrator

Division of Facilities Management

410 Federal Street, Suite \#2

O'Neill Building

Dover, DE 19903

(302) 739-5644

Fax: (302) 739-6148

URL: CSMISSON@STATE.DE.US

Delaware Public Service Commission

Bruce H. Burcat, Executive Director

1560 South Dupont Highway

Dover, DE 19901

(302) $739-4247$

Fax: (302) 739-4849

District of Columbia

City Energy Office

Charles J. Clinton, Director

District of Columbia Energy Office

2000 14th Street, N.W., Suite 300E

Washington, DC 20009

(202) 673-6750

Fax: (202) 673-6725

Public Service Commission Marlene L. Johnson, Esq., Chairperson 717 14th Street, N.W.

Washington, DC 20005

(202) 626-5100

Fax: (202) 393-1389

Florida

State Energy Office

William J. Tait, Director

Department of Community Affairs

2555 Shumard Oak Boulevard

Tallahassee, FL 32399-2100

(850) $488-2475$

Fax: (850) $488-7688$ 
Public Service Commission

William D. Talbott, Executive Director

2540 Shumard Oak Boulevard

Tallahassee, FL 32399-0850

(850) 413-6055

Fax: (850) 413-6052

\section{Georgia}

\section{State Energy Office}

Paul Burks

Georgia Environmental Facilities Authority

100 Peachtree Street, N.W.

2090 Equitable Building

Atlanta, GA 30303

(404) 656-0938

Fax: (404) 656-6416

Fax: (404) 656-7970 (Division of Energy)

\section{Public Service Commission}

B. B. Knowles, Director of Utilities

47 Trinity Avenue

Atlanta, GA 30334

(404) 656-4501

Fax: (404) 463-6532

\section{Guam}

State Energy Office

Fred P. Camacho, Director

Guam Energy Office

1504 East Sunset Boulevard

Tiyan, GU 96913

(671) 477-0557

Fax: (671) 477-0589

Hawaii

State Energy Office

Maurice H. Kaya, Administrator

Energy, Resources, and Technology

Division

Department of Business, Economic

Development and Tourism

P.O. Box 2359

Honolulu, HI 96804

(808) $587-3812$

Fax: (808) 586-2536

Public Utilities Commission

Chairman

465 S. King Street, \#103

Honolulu, HI 96813

(808) 586-2020

Fax: (808) 586-2066
Idaho

State Energy Office

Karl Dreher, Director

Idaho Department of Water Resources

1301 North Orchard Street

Boise, ID 83706

(208) 327-7900

Fax: (208) 327-7866

Public Utilities Commission

Stephanie Miller, Administrator

Utilities Division

P.O. Box 83720

Boise, ID 83720-0074

(208) 334-0366

Fax: (208) 334-3762

Illinois

Department of Commerce and Community

Affairs

Mitch Beaver, Deputy Director

Bureau of Energy and Recycling

$325 \mathrm{~W}$. Adams Street, \#300

Springfield, IL 62704-1892

(217) $785-2800$

Fax: (217) 785-2618

Commerce Commission

Donna M. Caton, Chief Clerk

527 E. Capitol Avenue

Box 19280

Springfield, IL 62794-9280

(217) 782-7434

Fax: (217) 524-0673

Indiana

Indiana Department of Commerce Cheryl L. DeVol-Glowinski, Director

Energy Policy Division

One North Capitol, Suite 700

Indianapolis, IN 46204-2288

(317) 232-8939

Fax: (317) 232-8995

Utility Regulatory Commission

302 West Washington Street

Suite E-306

Indianapolis, IN 46204

(317) 232-2701

Fax: (317) 232-6758 
Iowa

State Energy Office

Larry Bean, Administrator

Iowa Department of Natural Resources

Energy and Geological Resources Division

502 E. $9^{\text {th }}$ Street

Des Moines, IA 50319

(515) 281-4308

Fax: (515) 281-6794

Sharon A. Tahtinen, Chief

Energy Bureau

Iowa Department of Natural Resources

502 E. $9^{\text {th }}$ Street

Des Moines, IA 50319

(515) 281-7066

Fax: (515) 281-6794

Iowa Utilities Board

Raymond K. Vawter, Executive Secretary

Lucas State Office Building

Des Moines, IA 50319

(515) 281-5256

Fax: (515) 281-5329

Kansas

State Energy Office

Jim Ploger, Energy Program Manager

Energy Programs

Kansas Corporation Commission

1500 S.W. Arrowhead Road

Topeka, KS 66604-4027

(785) 271-3349

Fax: (785) 271-3268

Corporation Commission

John Wine, Chairman

Kansas Corporation Commission

1500 S.W. Arrowhead Road

Topeka, KS 66604

(785) 271-3100

Fax: (785) 271-3354

\section{Kentucky}

State Energy Office

John M. Stapleton, Director

Kentucky Division of Energy

663 Teton Trail

Frankfort, KY 40601

(502) 564-7192

Fax: (502) 564-7484
Public Service Commission

Helen Helton, Executive Director

730 Schenkel Lane, Box 615

Frankfort, KY 40602

(502) $564-3940$

Fax: (502) $564-3460$

Louisiana

State Energy Office

Paula Ridgeway

Louisiana Department of Natural Resources

P.O. Box 44156

Baton Rouge, LA 70804-4156

(504) 342-1399

Fax: (504) 342-1397

Public Service Commission

Lawrence C. St. Blanc, Secretary

Suite 1630, One American Place

Baton Rouge, LA 70825

(504) $342-4427$

Fax: (504) 342-4087

Mail letters to:

P.O. Box 91154

Baton Rouge, LA 70821-9154

Maine

State Energy Office

Brian K. Dancause, Supervisor

Energy Conservation Division

Department of Economic and Community

Development

59 State House Station

Augusta, ME 04333

(207) $287-2656$

Fax: (207) 287-5701

Public Utilities Commission

Christoper P. Simpson, Administrative

Director

18 State House Station

242 State Street

Augusta, ME 04333

(207) 287-3831

Fax: (207) 287-1039

Maryland

State Energy Office

Frederick H. Hoover, Jr., Director

Maryland Energy Administration

45 Calvert Street, 4 th Floor 
Annapolis, MD 21401

(410) 260-7511

Fax: (410) 974-2250

Public Service Commission

Daniel P. Gahagan

6 St. Paul Centre

Baltimore, MD 21202-6806

(410) 767-8067

Fax: (410) 333-6495

Massachusetts

State Energy Office

David L. O'Connor, Commissioner

Massachusetts Division of Energy Resources

Leverett Saltonstall Building

100 Cambridge Street, Room 1500

Boston, MA 02202

(617) 727-4732

Fax: (617) 727-0030

E-Mail: energy@state.ma.us

URL: http://www.magnet.state.ma.us/doer

Department of Telecommunications and Energy

100 Cambridge Street, 12th Floor

Boston, MA 02202

(617) $305-3500$

Fax: (617) 723-8812

URL: http://www.magnet.state.ma.us/dpu/

\section{Michigan}

Public Service Commission

John Strand, Chairman

Michigan Public Service Commission

P.O. Box 30221

6545 Mercantile Way

Lansing, MI 48909

(517) $334-6370$

Fax: (517) 882-5002

\section{Minnesota}

\section{State Energy Office}

Krista L. Sanda, Commissioner

Department of Public Service

121 7th Place East, Suite 200

St. Paul, MN 55101-2145

(651) 296-7107

Fax: (651) 297-1959

Public Utilities Commission

Rick Lancaster, Executive Secretary

121 Seventh Place East, Suite 350
St. Paul, MN 55101-2147

(651) 296-7124

Fax: (651) 297-7073

Mississippi

State Energy Office

Chester B. Smith, Director

Mississippi Department of Economic and

Community Development

Energy Division

P.O. Box 850

Jackson, MS 39205-0850

(601) $359-6600$

Fax: (601) 359-6642

Mississippi Public Utilities Staff

Robert G. Waites, Director

Room 1738, Walter Sillers State Office

Building

P.O. Box 1174

Jackson, MS 39215-1174

(601) $961-5493$

Fax: (601) 961-5804

Missouri

State Energy Office

Division of Energy

Missouri Department of Natural Resources

P.O. Box 176

Jefferson City, MO 65102

(573) $751-4000$

Fax: (573) 751-6860

Public Service Commission

Gordon Persinger

Executive Secretary

P.O. Box 360

Jefferson City, MO 65102

(573) $751-3234$

Fax: (573) 526-7341

Montana

State Energy Office

Van Jamison, Administrator

Department of Environmental Quality

Planning, Prevention and Assistance Division

1520 East Sixth Avenue

Helena, MT 59620-0901

(406) 444-6812

Fax: (406) 444-1804 
Public Service Commission

Kathy Anderson, Commission Secretary

1701 Prospect Avenue

Helena, MT 59620

(406) 444-6170

Fax: (406) 444-7618

Nebraska

\section{State Energy Office}

Robert Harris, Director

Nebraska Energy Office

The Atrium, 1st Floor

1200 N Street, Suite 110

Lincoln, NE 68509

(402) $471-2867$

Fax: (402) 471-3064

Public Service Commission

M. G. Hand, Chief Engineer

300 The Atrium

1200 N Street, P. O. Box 94927

Lincoln, NE 68509-4927

(402) 471-3101

Fax: (402) 471-0254

Nevada

\section{State Energy Office}

DeeAnn Parsons, Chief

Nevada State Energy Office

1050 East William, Suite 435

Carson City, NV 89710

(702) $687-4910$

Fax: (702) 687-4914

Public Service Commission

William H. Vance, Secretary

727 Fairview Drive

Carson City, NV 89710

(702) 687-6007

Fax: (702) 687-6110

\section{New Hampshire}

\section{State Energy Office}

Deborah Schachter, Director

Office of Energy and Community Service

57 Regional Drive

Concord, NH 03301-8519

(603) 271-2711

Fax: (603) 271-2615
Public Utilities Commission

Thomas B. Getz, Executive Director

8 Old Suncook Road

Concord, NH 03301-7319

(603) 271-2431

Fax: (603) 271-3878

New Jersey

New Jersey Board of Public Utilities

Herbert Tate, President

2 Gateway Center, 8th Floor

Newark, NJ 07102

(973) 648-2503

Fax: (973) 648-4195

Robert Chilton, Director

Division of Gas, Electric and Energy

2 Gateway Center, 9 th Floor

Newark, NJ 07102

(973) 648-3621

Fax: (973) 648-2467

New Mexico

State Energy Office

Dianne Caron, Director

Energy Conservation \& Management Division

Energy, Minerals \& Natural Resources

Department

2040 South Pacheco

Santa Fe, NM 87505

(505) $827-4323$

Fax: (505) 827-5870

Public Utility Commission

Dave Warren, Executive Director

224 E. Palace

Santa Fe, NM 87501

(505) 827-6940

Fax: (505) 827-6973

\section{New York}

Department of Public Service

John C. Crary, Secretary

3 Empire State Plaza

Albany, NY 12223-1350

(518) $474-6530$

Fax: (518) 486-6081

E-Mail: web@dps.state.ny.us 


\section{North Carolina}

State Energy Office

T. C. Adams, III, Director

North Carolina Department of Commerce

Energy Division

430 North Salisbury Street

P.O. Box 25249

Raleigh, NC 27611

(919) 733-1889

Fax: (919) 733-2953

Public Utilities Commission

Robert P. Gruber, Executive Director

Public Staff, P.O. Box 29520

Raleigh, NC 27626-0520

(919) 733-2435

Fax: (919) 733-9565

\section{North Dakota}

\section{State Energy Office}

Kim Christianson

Energy Program Manager

Office of Intergovernmental Assistance

State Capitol Building

600 E. Boulevard Avenue, 14th Floor

Bismarck, ND 58505-0170

(701) 328-2094

Fax: (701) 328-2308

Public Service Commission

Jon H. Mielke, Executive Secretary

State Capitol

Bismarck, ND 58505

(701) 328-2400

Fax: (701) 328-2410

\section{Ohio}

\section{State Energy Office}

Donald Jakeway, Director

Ohio Department of Development

Community Development Division

Office of Energy Efficiency

77 S. High Street, 26th Floor

Columbus, $\mathrm{OH}$ 43266-0413

(614) 466-6797

Fax: (614) 466-1864

\section{State Oil and Gas Agency}

Thomas G. Tugend, Acting Chief

Department of Natural Resources

Division of Oil and Gas

Fountain Square B-3
Columbus, $\mathrm{OH} 43224$

(614) 265-6922

Fax: (614) $268-4316$

Public Utilities Commission

Gary Vigorito, Director

Administration and Commission Secretary

180 E. Broad Street

Columbus, $\mathrm{OH}$ 43266-0573

(614) 466-4294

Fax: (614) 644-9546

Oklahoma

Secretary of Energy

Mike Smith

125 N.W. Sixth Street

Oklahoma City, OK 73105

(405) 235-4204

Fax: (405) 522-3492

State Alternative Fuels Office Jeanie Robards, Administrator Alternative Fuels Program Department of Central Services 3301 North Santa Fe

Oklahoma City, OK 73118

(405) 521-4687

Fax: (405) 525-2682

State Energy Office

Brenda Williams

Oklahoma Department of Commerce

Division of Community Affairs and

Development

P.O. Box 26980

Oklahoma City, OK 73126-0980

(405) 815-5351

Fax: (405) 815-5344

Oklahoma Corporation Commission Ernest G. Johnson, Director

Public Utility Division

$500 \mathrm{Jim}$ Thorpe Office Building

2101 North Lincoln Boulevard

Oklahoma City, OK 73105

(405) 521-3908

Fax: (405) 522-3371

Larry A. Schroeder, Deputy Director (405) 521-2518 
Oregon

State Energy Office

John Savage, Director

Oregon Department of Energy

625 Marion Street NE

Salem, OR 97310-0831

(503) $378-4040$

Fax: (503) 373-7806

Public Utility Commission

Ron Eachus, Commissioner

550 Capitol Street, N.E.

Salem, OR 97310-1380

(503) 378-6611

Fax: (503) 378-5505

Pennsylvania

State Oil and Gas Agency

James E. Erb, Director

Department of Environmental Protection

Bureau of Oil and Gas Management

Box 8765

Harrisburg, PA 17105-8765

(717) $772-2199$

Fax: (717) 772-2291

Public Utility Commission

Z. Ahmed Kaloko, Director

Bureau of Conservation, Economics

and Energy. Planning

Barto Building

Harrisburg, PA 17105-3265

(717) $787-2139$

Fax: (717) 787-2545

\section{Puerto Rico}

\section{State Energy Office}

Rafael Llompart, Administrator

Energy Affairs Administration

Department of Natural and Environmental

Resources

Puerto de Tierra

P.O. Box 5887

San Juan, PR 00906-5887

(787) $723-3636$

Fax: (787) 721-3084

Rhode Island

State Energy Office

Janis McClanaghan, Chief

Rhode Island State Energy Office
1 Capitol Hill

Providence, RI 02908

(401) 222-3370

Fax: (401) 222-1260

Public Utilities Commission

James Malachowski, Chairman

100 Orange Street

Providence, RI 02903

(401) 222-3500

Fax: (401) 222-6805

\section{South Carolina}

State Energy Office

Mitchell M. Perkins, Director

1201 Main Street, Suite 820

Columbia, SC 29201

(803) 737-8030

Fax: (803) 737-9846

Public Service Commission

D. Wayne Burdett, Manager

Utilities Department

P.O. Box 11649

Columbia, SC 29211

(803) 737-5125

Fax: (803) 737-5199

\section{South Dakota}

\section{State Energy Program}

Ronald W. Wheeler, Commissioner

Governor's Office of Economic Development

711 East Wells Avenue

Pierre, SD 57501-3369

(605) 773-5032

Fax: (605) 773-3256

\section{Public Utilities Commission}

William Bullard, Jr., Executive Director

500 East Capitol

Pierre, SD 57501

(605) 773-3201

Fax: (605) 773-3809

Tennessee

State Energy Office

Cynthia Oliphant, Director

Tennessee Department of Economic and

Community Development

Energy Division

320 6th Avenue North, 6th Floor

Nashville, TN 37243-0405 
(615) $741-2994$

Fax: (615) 741-5070

Tennessee Regulatory Authority Melvin Malone, Chairman 460 James Robertson Parkway

Nashville, TN 37243-0505

(615) 741-2904

Fax: (615) 741-5015

Texas

State Oil and Gas Agency

David E. Schieck, Director

Oil and Gas Division

Railroad Commission of Texas

Box 12967

Austin, TX 78711-2967

(512) 463-6893

Fax: (512) 463-6780

Public Utility Commission of Texas

Public Information Office

P.O. Box 13326

Austin, TX 78711-3326

(512) $936-7140$

Fax: (512) 936-7003

Utah

Office of Energy Services

Joe Waller, Manager

Division of Community Development

324 South State Street, Suite 500

Salt Lake City, UT 84111

(801) 538-8690

Fax: (801) 538-8660

Public Service Commission

Julie Orchard, Commission Secretary

160 East 300 South

Salt Lake City, UT 84111

(801) 530-6716

Fax: (801) 530-6796

E-mail: psccal@state.ut.us

\section{Vermont}

Public Service Board

Susan M. Hudson, Clerk

112 State Street

Chittenden Bank Building, 4th Floor

Drawer 20

Montpelier, VT 05620-2701

(802) 828-2358
Fax: (802) 828-3351

Department of Public Services

Scudder Parker, Director

Energy Efficiency Division

112 State Street, Drawer 20

Montpelier, VT 05620-2601

(802) 828-4009

Fax: (802) 828-2342

URL: http://www.state.vt.us/psd

Virginia

State Energy Office

Stephen A. Walz, Director

Division of Energy

Department of Mines, Minerals and Energy

202 N. Ninth Street, 8th Floor

Richmond, VA 23219

(804) 692-3211

Fax: (802) 692-3238

State Corporation Commission

William J. Bridge, Clerk of the Commission

Tyler Building, 1300 E. Main Street

P.O. Box 1197

Richmond, VA 23218-1197

(804) 371-9733

Fax: (804) 371-9133

Virgin Islands

Energy Office

Alicia Barnes James, Director

Virgin Islands Energy Office

Old Customs House

200 Strand Street

St. Croix, VI 00840

(340) $772-2616$

Fax: (340) 772-0063

Washington

State Energy Policy

K. C. Golden, Assistant Director

Energy Policy Division

Department of Community, Trade,

and Economic Development

925 Plum Street, SE, Bldg. \#4

P.O. Box 43173

Olympa, WA $98504-3173$

(360) 956-2006

Fax: (360) 956-2180 
Utilities and Transportation Commission

Mary Lu White, Librarian

WUTC Library Services

P.O. Box 47250

Olympia, WA 98504-7250

(360) 664-1199

Fax: (360) 586-1145

West Virginia

\section{State Energy Office}

John F. (Jeff) Herholdt, Jr.

West Virginia Development Office

Energy Efficiency Program

Building 6, 645 Capital Complex

Charleston, WV 25305

(304) 558-0350

Fax: (304) 558-0362

Public Service Commission

Pamela J. Hicks

201 Brooks Street

P.O. Box 812

Charleston, WV 25323

(304) 340-0426

Fax: (304) 340-0325

\section{Wisconsin}

\section{State Energy Office}

Nathaniel E. Robinson, Administrator

Wisconsin Division of Energy and

Intergovernmental Relations

101 East Wilson Street, 6th Floor

P.O. Box 7868

Madison, WI 53707-7868

(608) 266-8234

Fax: (608) 267-6931
Public Service Commission

Jeffrey L. Butson

Public Affairs Director

610 North Whitney Way

Madison, WI 53705-2729

(608) 267-0912

Fax: (608) 266-1401

Wyoming

State Energy Office

John F. Nunley, III, Supervisor

Federal Grants

Wyoming Business Council

First Floor East, Herschler Building

Cheyenne, WY 82002

(307) 777-6420

Fax: (307) 777-5840

Public Service Commission

2515 Warren Avenue

Cheyenne, WY 82002

(307) 777-7427

Fax: (307) 777-5700 


\section{Glossary}

Alternating Current: An electric current that reverses its direction at regularly recurring intervals, usually 50 or 60 times per second.

Amorphous Silicon: An alloy of silica and hydrogen, with a disordered, noncrystalline internal atomic arrangement, that can be deposited in thin-layers ( $a$ few micrometers in thickness) by a number of deposition methods to produce thin-film photovoltaic cells on glass, metal, or plastic substrates.

Annualized Growth Rates: Calculated as follows:

$$
\left(x_{n} / x_{1}\right)^{1 / n}
$$

where $x$ is the value under consideration and $n$ is the number of periods.

Aquifer: A subsurface rock unit from which water can . be produced.

ARI: Air-Conditioning and Refrigeration Institute

Availability Factor: A percentage representing the number of hours a generating unit is available to produce power (regardless of the amount of power) in a given period, compared to the number of hours in the period.

Biodiesel: A renewable fuel synthesized from soy beans, other oil crops, or animal tallow which can substitute for petroleum diesel fuel.

Biomass: Organic nonfossil material of biological origin constituting a renewable energy source.

Black Liquor: A byproduct of the paper production process that can be used as a source of energy.

Capacity Factor: The ratio of the electrical energy produced by a generating unit for the period of time considered to the electrical energy that could have been produced at continuous full-power operation during the same period.

Capacity, Gross: The full-load continuous rating of a generator, prime mover, or other electric equipment under specified conditions as designated by the manufacturer. It is usually indicated on a nameplate attached to the equipment.

Capital Cost: The cost of field development and plant construction and the equipment required for the generation of electricity.

Cast Silicon: Crystalline silicon obtained by pouring pure molten silicon into a vertical mold and adjusting the temperature gradient along the mold volume during cooling to obtain slow, vertically-advancing crystallization of the silicon. The polycrystalline ingot thus formed is composed of large, relatively parallel, interlocking crystals. The cast ingots are sawed into wafers for further fabrication into photovoltaic cells. Cast-silicon wafers and ribbon-silicon sheets fabricated into cells are usually referred to as polycrystalline photovoltaic cells.

Climate Change (Greenhouse Effect): The increasing mean global surface temperature of the Earth caused by gases in the atmosphere (including carbon dioxide, methane, nitrous oxide, ozone, and chlorofluorocarbons). The greenhouse effect allows solar radiation to penetrate the Earth's atmosphere but absorbs the infrared radiation returning to space.

Cogeneration: The production of electrical energy and another form of useful energy (such as heat or steam) through the sequential use of energy.

Combined Cycle: An electric generating technology in which electricity is produced from otherwise lost waste heat exiting from one or more gas (combustion) turbines. The exiting heat is routed to a conventional boiler or to a heat recovery steam generator for utilization by a steam turbine in the production of electricity. Such designs increase the efficiency of the electric generating unit.

Concentrator: A reflective or refractive device that focuses incident insolation onto an area smaller than the reflective or refractive surface, resulting in increased insolation at the point of focus. 
Cull Wood: Wood logs, chips, or wood products that are burned.

Direct Current: An electric current that flows in a constant direction. The magnitude of the current does not vary or has a slight variation.

Electric Utility Restructuring: With some notable exceptions, the electric power industry historically has been composed primarily of investor-owned utilities. These utilities have been predominantly vertically integrated monopolies (combining electricity generation, transmission, and distribution), whose prices have been regulated by State and Federal government agencies. Restructuring the industry entails the introduction of competition into at least the generation phase of electricity production, with a corresponding decrease in regulatory control. Restructuring may also modify or eliminate other traditional aspects of investor-owned utilities, including their exclusive franchise to serve a given geographical area, assured rates of return, and vertical integration of the production process.

Emission: The release or discharge of a substance into the environment; generally refers to the release of gases or particulates into the air.

Evacuated Tube: In a solar thermal collector, an absorber tube, which is contained in an evacuated glass cylinder, through which collector fluids flows.

Exempt Wholesale Generator (EWG): A nonutility electricity generator that is not a qualifying facility under the Public Utility Regulatory Policies Act of 1978.

Externalities: Benefits or costs, generated as a byproduct of an economic activity, that do not accrue to the parties involved in the activity. Environmental externalities are benefits or costs that manifest themselves through changes in the physical or biological environment.

Flat Plate Pumped: A medium-temperature solar thermal collector that typically consists of a metal frame, glazing, absorbers (usually metal), and insulation and that uses a pump liquid as the heat-transfer medium: predominant use is in water heating applications.

Flow Control: The laws, regulations, and economic incentives or disincentives used by waste managers to direct waste generated in a specific geographic area to a designated landfill, recycling, or waste-to-energy facility.

Fuel Cells: One or more cells capable of generating an electrical current by converting the chemical energy of a fuel directly into electrical energy. Fuel cells differ from conventional electrical cells in that the active materials such as fuel and oxygen are not contained within the cell but are supplied from outside.

Fuelwood: Wood and wood products, possibly including coppices, scrubs, branches, etc., bought or gathered, and used by direct combustion.

Fumarole: A vent from which steam or gases issue; a geyser or spring that emits gases.

Generation (Electricity): The process of producing electric energy from other forms of energy; also, the amount of electric energy produced, expressed in watthours $(\mathrm{Wh})$.

Geopressured: A type of geothermal resource occurring in deep basins in which the fluid is under very high pressure.

Geothermal Energy: As used at electric utilities, hot water or steam extracted from geothermal reservoirs in the Earth's crust that is supplied to steam turbines at electric utilities that drive generators to produce electricity.

Geothermal Plant: A plant in which a turbine is driven either from hot water or by natural steam that derives its energy from heat found in rocks or fluids at various depths beneath the surface of the earth. The fluids are extracted by drilling and/or pumping.

Geyser: A special type of thermal spring that periodically ejects water with great force.

Giga: One billion.

Green Pricing: In the case of renewable electricity, green pricing represents a market solution to the various problems associated with regulatory valuation of the nonmarket benefits of renewables. Green pricing programs allow electricity customers to express their willingness to pay for renewable energy development through direct payments on their monthly utility bills.

Grid: The layout of an electrical distribution system.

Groundwater: Water occurring in the subsurface zone where all spaces are filled with water under pressure greater than that of the atmosphere.

Heat Pump: A year-round heating and air-conditioning system employing a refrigeration cycle. In a refrigeration cycle, a refrigerant is compressed (as a 
liquid) and expanded (as a vapor) to absorb and reject heat. The heat pump transfers heat to a space to be heated during the winter period and by reversing the operation extracts (absorbs) heat from the same space to be cooled during the summer period. The refrigerant within the heat pump in the heating mode absorbs the heat to be supplied to the space to be heated from an outside medium (air, ground or ground water) and in the cooling mode absorbs heat from the space to be cooled to be rejected to the outside medium.

Heat Pump (Air Source): An air-source heat pump is the most common type of heat pump. The heat pump absorbs heat from the outside air and transfers the heat to the space to be heated in the heating mode. In the cooling mode the heat pump absorbs heat from the space to be cooled and rejects the heat to the outside air. In the heating mode when the outside air approaches $32^{\circ}$ $F$ or less, air-source heat pumps loose efficiency and generally require a back-up (resistance) heating system.

Heat Pump (Geothermal): A heat pump in which the refrigerant exchanges heat (in a heat exchanger) with a fluid circulating through an earth connection medium (ground or ground water). The fluid is contained in a variety of loop (pipe) configurations depending on the temperature of the ground and the ground area available. Loops may be installed horizontally or vertically in the ground or submersed in a body of water.

Heat Pump (efficiency): The efficiency of a heat pump, that is, the electrical energy to operate it, is directly related to temperatures between which it operates. Geothermal heat pumps are more efficient than conventional heat pumps or air conditioners that use the outdoor air since the ground or ground water a few feet below the earth's surface remains relatively constant throughout the year. It is more efficient in the winter to draw heat from the relatively warm ground than from the atmosphere where the air temperature is much colder, and in summer transfer waste heat to the relatively cool ground than to hotter air. Geothermal heat pumps are generally more expensive $(\$ 2,000-\$ 5,000)$ to install than outside air heat pumps. However, depending on the location geothermal heat pumps can reduce energy consumption (operating cost) and correspondingly, emissions by more than 20 percent compared to high-efficiency outside air heat pumps. Geothermal heat pumps also use the waste heat from air conditioning to provide free hot water heating in the summer
High-Temperature Collector: A solar thermal collector designed to operate at a temperature of 180 degrees Fahrenheit or higher.

Hot Dry Rock: Heat energy residing in impermeable, crystalline rock. Hydraulic fracturing may be used to create permeability to enable circulation of water and removal of the heat.

Hub Height: In a horizontal-axis wind turbine, the distance from the turbine platform to the rotor shaft.

Hydraulic Fracturing: Fracturing of rock at depth with fluid pressure. Hydraulic fracturing at depth may be accomplished by pumping water into a well at very high pressures. Under natural conditions, vapor pressure may rise high enough to cause fracturing in a process known as hydrothermal brecciation.

Independent Power Producer (IPP): A wholesale electricity producer (other than a qualifying facility under the Public Utility Regulatory Policies Act of 1978), that is unaffiliated with franchised utilities in the area in which the IPP is selling power and that lacks significant marketing power. Unlike traditional utilities, IPPs do not possess transmission facilities that are essential to their customers and do not sell power in any retail service territory where they have a franchise.

Internal Collector Storage (ICS): A solar thermal collector in which incident solar radiation is absorbed by the storage medium.

Kilowatt (kW): One thousand watts of electricity (See Watt).

Kilowatthour (kWh): One thousand watthours.

Levelized Cost: The present value of the total cost of building and operating a generating plant over its economic life, converted to equal annual payments. Costs are levelized in real dollars (i.e., adjusted to remove the impact of inflation).

Liquid Collector: A medium-temperature solar thermal collector, employed predominantly in water heating, which uses pumped liquid as the heat-transfer medium.

Low-Temperature Collectors: Metallic or nonmetallic solar thermal collectors that generally operate at temperatures below 110 degrees Fahrenheit and use pumped liquid or air as the heat transfer medium. They 
usually contain no glazing and no insulation, and they are often made of plastic or rubber, although some are made of metal.

Magma: Naturally occurring molten rock, generated within the earth and capable of intrusion and extrusion, from which igneous rocks are thought to have been derived through solidification and related processes. It may or may not contain suspended solids (such as crystals and rock fragments) and/or gas phases.

Marginal Cost: The change in cost associated with a unit change in quantity supplied or produced.

Medium-Temperature Collectors: Solar thermal collectors designed to operate in the temperature range: of 140 degrees to 180 degrees Fahrenheit, but that car! also operate at a temperature as low as 110 degrees Fahrenheit. The collector typically consists of a metal frame, metal absorption panels with integral flow channels (attached tubing for liquid collectors or integral ducting for air collectors), and glazing and insulation on the sides and back.

Megawatt (MW): One million watts of electricity (See Watt).

Merchant Facilities: High-risk, high-profit facilities that operate, at least partially, at the whims of the market, as opposed to those facilities that are constructed with. close cooperation of municipalities and have significant: amounts of waste supply guaranteed.

Net Photovoltaic Cell Shipment: The difference between photovoltaic cell shipments and photovoltaic cell purchases.

Net Photovoltaic Module Shipment: The difference between photovoltaic module shipments and photovoltaic module purchases.

Nonutility Generation: Electric generation by end-users, independent power producers, or small power producers under the Public Utility Regulatory Policies Act, to supply electric power for industrial, commercial, and military operations, or sales to electric utilities.

Operation and Maintenance (O\&M) Cost: Operating; expenses are associated with operating a facility (i.e., supervising and engineering expenses). Maintenance expenses are that portion of expenses consisting of labor, materials, and other direct and indirect expenses incurred for preserving the operating efficiency or physical condition of utility plants that are used for power production, transmission, and distribution of energy.

Parabolic Dish: A high-temperature (above 180 degrees Fahrenheit) solar thermal concentrator, generally bowlshaped, with two-axis tracking.

Parabolic Trough: A high-temperature (above 180 degrees Fahrenheit) solar thermal concentrator with the capacity for tracking the sun using one axis of rotation.

Passive Solar: A system in which solar energy alone is used for the transfer of thermal energy. Pumps, blowers, or other heat transfer devices that use energy other than solar are not used.

Peak Watt: A manufacturer's unit indicating the amount of power a photovoltaic cell or module will produce at standard test conditions (normally 1,000 watts per square meter and 25 degrees Celsius).

Photovoltaic Cell: An electronic device consisting of layers of semiconductor materials fabricated to form a junction (adjacent layers of materials with different electronic characteristics) and electrical contacts and being capable of converting incident light directly into electricity (direct current).

Photovoltaic Module: An integrated assembly of interconnected photovoltaic cells designed to deliver a selected level of working voltage and current at its output terminals, packaged for protection against environment degradation, and suited for incorporation in photovoltaic power systems.

Public Utility Regulatory Policies Act of 1978 (PURPA): One part of the National Energy Act, PURPA contains measures designed to encourage the conservation of energy, more efficient use of resources, and equitable rates. Principal among these were suggested retail rate reforms and new incentives for production of electricity by cogenerators and users of renewable resources.

Pulpwood: Roundwood, whole-tree chips, or wood residues.

Quadrillion Btu: Equivalent to 10 to the 15 th power Btu.

Qualifying Facility (QF): A cogeneration or small power production facility that meets certain ownership, operating, and efficiency criteria established by the Federal Energy Regulatory Commission (FERC) pursuant to the Public Utility Regulatory Policies Act of 1978 
(PURPA). (See the Code of Federal Regulations, Title 18, Part 292.)

Refuse-Derived Fuel (RDF): Fuel processed from municipal solid waste that can be in shredded, fluff, or densified pellet forms.

Renewable Energy Source: An energy source that is regenerative or virtually inexhaustible. Typical examples are wind, geothermal, and water power.

Ribbon Silicon: Single-crystal silicon derived by means of fabricating processes that produce sheets or ribbons of single-crystal silicon. These processes include edgedefined film-fed growth, dendritic web growth, and ribbon-to-ribbon growth.

Roundwood: Logs, bolts, and other round timber generated from the harvesting of trees.

Silicon: A semiconductor material made from silica, purified for photovoltaic applications.

Single Crystal Silicon (Czochralski): An extremely pure form of crystalline silicon produced by the Czochralski method of dipping a single crystal seed into a pool of molten silicon under high vacuum conditions and slowly withdrawing a solidifying single crystal boule rod of silicon. The boule is sawed into thin wafers and fabricated into single-crystal photovoltaic cells.

Solar Energy: The radiant energy of the sun, which can be converted into other forms of energy, such as heat or electricity.

Solar Thermal Collector: A device designed to receive solar radiation and convert it into thermal energy. Normally, a solar thermal collector includes a frame, glazing, and an absorber, together with the appropriate insulation. The heat collected by the solar thermal collector may be used immediately or stored for later use.

Solar Thermal Collector, Special: An evacuated tube collector or a concentrating (focusing) collector. Special collectors operate in the temperature (low concentration for pool heating) to several hundred degrees Fahrenheit (high concentration for air conditioning and specialized industrial processes).

Thermosiphon System: A solar collector system for water heating in which circulation of the collection fluid through the storage loop is provided solely by the temperature and density difference between the hot and cold fluids.

Tipping Fee: Price charged to deliver municipal solid waste to a landfill, waste-to-energy facility, or recycling facility.

Transmission System (Electric): An interconnected group of electric transmission lines and associated equipment for moving or transferring electric energy in bulk between points of supply and points at which it is transformed for delivery over the distribution system lines to consumers, or is delivered to other electric systems.

Turbine: A machine for generating rotary mechanical power from the energy of a stream of fluid (such as water, steam, or hot gas). Turbines convert the kinetic energy of fluids to mechanical energy through the principles of impulse and reaction, or a mixture of the two.

Vapor-Dominated Geothermal System: A conceptual model of a hydrothermal system where steam pervades the rock and is the pressure-controlling fluid phase.

Watt (Electric): The electrical unit of power. The rate of energy transfer equivalent to 1 ampere of electric current flowing under a pressure of 1 volt at unity power factor.

Watt (Thermal): A unit of power in the metric system, expressed in terms of energy per second, equal to the work done at a rate of 1 joule per second.

Watthour (Wh): The electrical energy unit of measure equal to 1 watt of power supplied to, or taken from, an electric circuit steadily for 1 hour.

Wheeling: The use of the transmission facilities of one system to transmit power and energy by agreement of and for, another system with a corresponding wheeling charge, e.g., the transmission of electricity for compensation over a system that is received from one system and delivered to another system).

Wood Pellets: Fuel manufactured from finely ground wood fiber and used in pellet stoves. 